\title{
BRACTWA CHARYTATYWNE W POLSCE OD ŚREDNIOWIECZA DO KOŃCA XVIII WIEKU
}

\section{Wprowadzenie}

Jedną z instytucji, oprócz szkół i szpitali, jaka w minionych wiekach odgrywała ważną rolę w życiu poszczególnych parafii, a szerzej także w życiu społeczności miast i w nieco mniejszym stopniu wsi, były bractwa religijne. Wraz z cechami stanowiły one jedną z ważniejszych dziedzin historii społeczno-religijnej ${ }^{1}$. Były to stowarzyszenia - wspólnoty przykościelne, posiadające osobowość prawną, zrzeszające ludzi w celach religijnych bez względu na płeć i pochodzenie społeczne ${ }^{2}$. Bractwa jako stowarzyszenia ludzi świeckich, znane były już w starożytności pogańskiej. Wspomnieć tu należy o rozwijających się w okresie imperialnym Rzymu kolegiach rzymskich, na czele z kolegiami pogrzebowymi, które organizowały pogrzeby dla zmarłych członków i pomagały po śmierci ich rodzinom $^{3}$. Chrześcijaństwo z powodzeniem wykorzystało doświadczenia rzymskich kolegiów przy tworzeniu nowych wspólnot religijnych. ${ }^{4}$ Korzenie właściwych bractw religijnych (fraternitas) sięgają swymi początkami pierwszych wieków

* Marian Surdacki - prof. historii, kierownik Katedry Historii Opieki Społecznej, Wydział Nauk Społecznych KUL, e-mail: msurd@kul.lublin.pl

${ }^{1}$ J. Flaga, Rodzaje i terytorialne rozmieszczenie bractw religijnych $w$ diecezji krakowskiej w połowie XVIII wieku, w: Ius et lex. Księga jubileuszowa ku czci profesora Adama Strzembosza, red. A. Dębiński, A. Grześkowiak, K. Wilk, Lublin 2002, s. 561. M Surdacki, Bractwa religijne w Urzędowie w XVI-XVIII wieku, „Kwartalnik Historii Kultury Materialnej”, 51 (2003) nr 3-4, s. 355; E. Wiśniowski, Bractwa religijne na ziemiach polskich w średniowieczu, ,Roczniki Humanistyczne", 17 (1969) z. 2, s. 51.

${ }^{2}$ I. Czarciński, Bractwa $w$ wielkich miastach państwa krzyżackiego w średniowieczu, Toruń 1993, s. 15.

${ }^{3}$ La caritŕ cristiana in Roma, a cura di V. Monachino, Bologna 1968, s. 28-33; E. Wipszycka, Świeckie bractwa w życiu religijnym chrześcijańskiego Egiptu, „Przegląd Historyczny”, 59 (1968) z. 3, s. 447.

${ }^{4}$ Wipszycka, Świeckie bractwa, s. 447; K. Kuźmak, B. Natoński, Bractwo Miłosierdzia, w: Encyklopedia katolicka (dalej: EK), t. 2, Lublin 1985, kol. 1022. 
chrześcijaństwa, nawet jeszcze okresu przedkonstantyńskiego, kiedy to stowarzyszenia grabarzy, zajmowały się grzebaniem zmarłych w katakumbach i utrzymywaniem cmentarzy. Prototypy bractw dewocyjno-ascetycznych prężniej działały w IV-V wieku, zwłaszcza wśród kleru, roztaczającego szczególną troskę nad chorymi $^{5}$. W Konstantynopolu istniały bractwa pogrzebowe. Tam też oraz w Rzymie i Egipcie rozwijały się organizacje żeńskie (diakonesy, „stowarzyszenia gorliwych dziewic") poświęcające się opiece nad chorymi kobietami. Istniało też wiele innych wspólnot brackich podejmujących charytatywną misję w rodzących się wtedy różnego rodzaju hospicjach i szpitalach wczesnochrześcijańskich ${ }^{6}$.

W drugiej połowie pierwszego tysiąclecia rozwijały się modlitewne wspólnoty zakonne u benedyktynów oraz wspólnoty kleru świeckiego. Tworzyły się też poza klasztorami bractwa złożone z ludzi świeckich, które w IX w. były już dobrze uformowane pod względem organizacyjnym. Były wśród nich także bractwa charytatywne. Szczególnie doniosłą role odgrywały bractwa szpitalnicze, które w XI-XII w. przejęły w swe ręce zarząd hospicjów związanych dotąd głównie z klasztorami ${ }^{7}$. Z reguły powstawały one przy istniejących już szpitalach, np. bractwo Św. Ducha przy szpitalu Św. Ducha w Rzymie), bardzo często same fundowały szpitale, niekiedy powierzano im w administrację już istniejące szpitale. Ponadto istniały bractwa w ogóle nie związane z żadną instytucją szpitalną lecz na własną rękę zajmujące się pomocą charytatywną. Szczególną postać stanowiły bractwa mostowe, zajmujące się opieką nad pielgrzymami oraz chorymi i ubogimi na drogach. Ich zadaniem było również budowanie mostów na rzekach i przełęczach dla podróżnych pątników ${ }^{8}$. Po części opiekuńczo-charytatywną specyfikę posiadały bractwa pokutne, pokojowe (homines pacis), czy bractwa zakapturzonych, czy kapturników (w Alvernii we Francji), świadczące miłosierdzie ubogim i chorym oraz występujące przeciwko uciskowi słabych i bezbronnych ze strony feudałów i rycerzy, jak też niesprawiedliwym wojnom9.

Różnego rodzaju organizacje brackie, w tym o charakterze dobroczynno-opiekuńczym, rozwijające się już w XI-XII w., stały się na Zachodzie zjawiskiem powszechnym wnastępnych stuleciach, zwłaszczaw XIV-XVw. ${ }^{10}$. W oparciu owzo-

${ }^{5}$ Wiśniowski, Bractwa religijne, s. 51-52; B. Kumor, Kościelne stowarzyszenia świeckich na ziemiach polskich $w$ okresie przedrozbiorowym, „Prawo Kanoniczne, 10 (1967) nr 1-2, s. 290; tenże, Kościelne stowarzyszenia świeckich na ziemiach polskich $w$ okresie przedrozbiorowym, w: Ksiega Tysiaclecia katolicyzmu w Polsce, red. M. Rechowicz, cz. 1, Lublin 1969, s. 504 (Jest to ten sam artykuł o identycznym tytule, dlatego identyfikacją przy ich cytowaniu będą strony); Z. Budzyński, Dzieje opieki społecznej w ziemi przemyskiej i sanockiej (XV-XVIII w.), Przemyśl-Kraków 1987, s. 157.

${ }^{6}$ La caritè cristiana, s. 50; K. Kuźmak, Bractwo kościelne, EK, t. 2, Lublin 1985, kol. 10131014.

${ }^{7}$ Wiśniowski, Bractwa religijne, s. 53.

${ }^{8}$ A. Pazzini, L'ospedale nei secoli, Roma 1958, s. 107; Wiśniowski, Bractwa religijne, s. 53; W. Bochnak, Religijne stowarzyszenia i bractwa katolików świeckich $w$ diecezji wrocławskiej od XI wieku do 1810 roku, Legnica 2000, s. 52.

${ }^{9}$ V. Paglia, Storia dei poveri in occidente, Milano 1994, s. 154-156, 184-185; Bochnak, Religijne stowarzyszenia, s. 53.

${ }^{10}$ Wiśniowski, Bractwa religijne, s. 54. 
ry zachodnioeuropejskie w XIII w. zaczęły się także korzenić na ziemiach polskich, a jako jedne z pierwszych pojawiły się u nas konfraternie opiekujące się ubogimi i wyspecjalizowane w prowadzeniu szpitali i działalności charytatywnej wśród osób niehospitalizowanych ${ }^{11}$.

\section{BRACTWA SZPITALNE}

Najstarsze tradycje spośród świeckich stowarzyszeń charytatywnych na ziemiach polskich posiadają bractwa szpitalne (fraternitas hospitales). Miały one na celu nie tyle fundowanie szpitali, ile dostarczanie ludzi, którzy bardzo często oddawali się pracy w szeroko zakreślonej działalności szpitalnictwa średniowiecznego. Służbę bliźniemu traktowano w nich jako bezpośrednią służbę Bogu (res sacra miser $)^{12}$. Tak jak i wszystkie inne bractwa religijne, najwcześniej, bo już w XIII w., pojawiły się na Śląsku, w diecezji wrocławskiej ${ }^{13}$, jakkolwiek najwcześniej obecność tego typu bractwa można było spotkać przy szpitalu św. Michała w Poznaniu w okresie od połowy XII w. do $1187 \mathrm{r}^{14}$. Korzenie bractw szpitalnych na Śląsku wiążą się z początkami niektórych tamtejszych szpitali. Bracia szpitalni sprawowali administrację i prowadzili posługę opiekuńczą przy szpitalu dla trędowatych kobiet pod Środą na Śląsku (1245), w szpitalach w Ziębicach (1250), Bolesławcu (przed 1261), Bolkowie (1295), Prusicach (1347). Prawdopodobnie bractwo szpitalne istniało też w tym okresie przez kilkanaście lat w szpitalu w Świdnicy ${ }^{15}$. W pierwszej fazie istnienia wymienionych szpitali, a na pewno w Środzie, Bolesłwcu i Bolkowie bractwa szpitalne zarządzały tymi placówkami. Można powiedzieć, że były to szpitale bractwa laickiego, z duchownym rektorem (prokuratorem lub prepozytem) na czele, pełniącym obowiązki duszpasterskie W stosunku do pensjonariuszy jak i samych współbraci ${ }^{16}$. W szpitalu średzkim, prowadzonym przez bractwo i braci szpitalnych, jego mieszkanki (,,siostry trędowate") prowadziły tryb życia na wzór zakonnego, oznacza to że wspólnota bracka przypominała dwukonwentowy klasztor ${ }^{17}$. Szpitale śląskie kierowane przez bractwa były, na wzór niemiecki, mocno związane z parafią. Przykładem tego był szpital w Bolkowie, w którym duszpasterstwo prowadził pleban i dopiero w 1298 roku biskup pozwolił, aby bracia wybierali sobie własnego plebana ${ }^{18}$.

${ }^{11}$ Budzyński, Dzieje opieki, s. 157; Kuźmak, Bractwo kościelne, kol. 1014.

${ }^{12}$ Kumor, Kościelne stowarzyszenia, s. 518; tenże, Kościelne stowarzyszenia, s. 319.

${ }^{13}$ S. Litak, Parafie w Rzeczypospolitej w XVI-XVIII wieku, Lublin 2004, s. 219; tenże, Bractwa religijne w Polsce przedrozbiorowej XIII-XVIII wiek. Rozwój i problematyka, „Przegląd Historyczny", 88 (1997) z. 3-4, s. 502.

${ }^{14}$ K. Dola, Opieka społeczna Kościoła, w: Historia Kościoła w Polsce, red. B. Kumor, Z. Obertyński, t. I, cz. 1, s. 174.

${ }^{15}$ W. Bochnak, Religijne stowarzyszenia, s. 92-96; K. Dola, Szpitale średniowieczne Ślaska. Rozwój historyczny, „Rocznik Teologiczny Śląska Opolskiego”, 1 (1968) s. 246, 263, 281, 283-285, 290; Kumor, Kościelne stowarzyszenia, s. 320; Wiśniowski, Bractwa religijne, s. 55; Litak, Parafie w Rzeczypospolitej, s. 219; Litak, Bractwa religijne, s. 502.

${ }^{16}$ Dola, Szpitale średniowieczne Ślaska, s. 246, 263-264, 283.

${ }^{17}$ K. Dola, Szpitale w średniowiecznej Polsce pod zarządem kościelnym. Studia Materiaty, Rzym 1972, s. 200; tenże, Szpitale średniowieczne Ślaska, s. 246.

${ }^{18}$ Tenże, Szpitale w średniowiecznej Polsce, s. 200, 208; tenże, Szpitale średniowieczne Śląska, s. $254,263-264$. 
Można spotkać opinię, że szpitale prowadzone przez laickie bractwa szpitalne, będące zarzewiem późniejszych zgromadzeń zakonnych, stanowiły w XII w. ważne zjawisko na terenie Włoch i Francji czy w sąsiednich Niemczech, zaś na terenie Polski występowały rzadko i w znikomym stopniu przygotowywały rozwój zakonów charytatywnych ${ }^{19}$. Jednakowoż liczba 43 szpitali brackich powstałych do końca XIV w. na Śląsku nakazuje tę tezę odnieść wyłącznie do ziem poza śląskich. Sieć szpitali prowadzonych przez bractwa laickie rozwijała się tu równocześnie z siecią placówek zakonów krzyżowych ${ }^{20}$. Szpitale brackie przeszczepione na Śląsk przejmowane były niebawem przez pojawiające się zakony szpitalne, a kierujące nimi bractwa szpitalne przyjmowały reguły zakonne ${ }^{21}$. Taki los spotkał szpitale w Ziębicach (w 1282 r.) czy Swidnicy (1283 r.), które zarządzane i obsługiwane przez bractwa, odpowiednio po ponad trzydziestu lub kilkunastu latach, zostały przekazane zakonowi krzyżaków z czerwoną gwiazdą, a bracia laicy w większości zdecydowali się przyjąć regułę zakonną. Z kolei w Poznaniu bractwo poddało się regule joannitów. W tym przypadku i wielu innych szpitale brackie przygotowały niejako drogę dla zakonów szpitalnych. Taki był zresztą naturalny bieg rzeczy, ponieważ największe zakony szpitalne i szpitalno-rycerskie wywodzą się właśnie ze skromnych bractw22. Przekazywanie szpitali brackich zakonom i lokalizacja szpitali krzyżowych w niemal wszystkich ważniejszych ośrodkach Śląska, Małopolski, Wielkopolski i Kujaw wskazują, że rozwiązanie takie uważano w XIII i XIV w. za lepsze niż powierzanie opieki bractwom lai$\mathrm{ckim}^{23}$. Brak jest dokładniejszych przekazów o strukturze bractw szpitalnych pod względem płci, jednakże przypadek bractwa w Bolkowie, w którym w 1304 r. w gronie administratorów występują procuratrix, pozwala wnioskować, że omawiane konfraternie posiadały charakter mieszany ${ }^{24}$.

Oprócz kilku stwierdzonych wyżej przypadków bractw szpitalnych, przypuszczać należy istnienie tego typu stowarzyszeń w większej ilości szpitali, zwłaszcza na Pomorzu i w Prusach, gdzie brak było zakonów szpitalnych ${ }^{25}$. Generalnie bractwa szpitalne okazały się tworem nietrwałym i lokalnym, ograniczonym tylko do terenów śląskich, gdzie najszybciej ukształtowały się struktury kościelne, a w związku z tym najwcześniej rozpoczął się proces zakładania szpitali.

${ }^{19}$ Tenże, Opieka społeczna Kościoła, s. 173; tenże, Szpitale w średniowiecznej Polsce, s. 200.

${ }^{20}$ M. Starnawska, Między Jerozolima a Łukowem. Zakony krzyżowe na ziemiach polskich w średniowieczu, Warszawa 1999, s. 233; Dola, Szpitale średniowieczne Śląska, s. 163-292 (aneksy).

${ }^{21}$ Dola, Szpitale w średniowiecznej Polsce, s. 200; tenże, Szpitale średniowieczne Śląska, s. 233 .

${ }^{22}$ Tenże, Szpitale średniowieczne Śląska, s. 246, 284-285, 290; tenże, Szpitale w średniowiecznej Polsce, s. 200-201; tenże, Opieka społeczna Kościoła, s. 174; U. Jonecko, A. Jonecko, Działalność szpitalna na Śląsku czeskich krzyżaków z czerwona gwiazda, „Archiwum Historii Medycyny”, 36 (1973) z. 4, s. 334. Zob. też Starnawska, Między Jerozolima a Łukowem, s. 233.

${ }^{23}$ Starnawska, Między Jerozolima a Łukowem, s. 233. Zob. rozdział dotyczący szpitali zakonnych w średniowieczu

${ }^{24}$ Dola, Opieka społeczna Kościoła, s. 174; tenże, Szpitale średniowieczne Ślaska, s. 246.

${ }^{25}$ Tenże, Opieka społeczna Kościoła, s. 174; Kumor, Kościelne stowarzyszenia, s. 519; tenże, Kościelne stowarzyszenia, s. 319. 
Stowarzyszenia te nie przetrwały zjawiska powszechnej ekspansji średniowiecznych szpitali zakonnych. Nie sprostawszy konkurencji zakonów charytatywnych, samoczynnie upadały lub zostały przez nie wchłonięte i przeszły pod ich zarząd. Nowe zakony szpitalne, $\mathrm{z}$ wyjątkiem duchaków, same złożone $\mathrm{z}$ braci, tym razem noszących habity, nie potrzebowały w prowadzonych przez siebie szpitalach dodatkowego wsparcia ze strony świeckich braci.

W grupie bractw szpitalnych, szczególne miejsce zajmowało świeckie bractwo Świętego Ducha, realizujące w szerokim zakresie cele charytatywne ${ }^{26}$. W przeciwieństwie jednak do wymienionych konfraterni śląskich czy pomorskich, świadczących posługę w różnych wczesnośredniowiecznych szpitalach lub utrzymujących te placówki, bractwo Ducha Świętego związane było tylko ze szpitalami prowadzonymi przez jeden konkretny zakon.

Założone przez Gwidona z Montpellier, obsługiwało ufundowany przez niego około $1175 \mathrm{r}$. w rodzinnym mieście szpital pod tym samym wezwaniem dla chorych, biednych oraz osieroconych i porzuconych dzieci. Po zatwierdzeniu w 1198 roku przez Innocentego III powstałego na jego bazie zakonu duchaków i ufundowaniu w tym samym czasie wzorcowego szpitala Świętego Ducha w Rzymie, bractwo zostało organicznie związane z nowym zakonem. Odtąd duchacy niemal zawsze zakładali je przy swoich szpitalach, dlatego rozwój bractwa uwarunkowany był działalnością zakonu. Szpital rzymski stał się domem głównym całego zakonu duchaków, a także bractwa, do którego mogli należeć zarówno mężczyźni, jak i kobiety ${ }^{27}$. Obowiązkiem braci zgromadzonych w konfraterni było m.in. częste odwiedzanie chorych w szpitalu, usługiwanie im, szukanie bezdomnych na ulicach i przynoszenie ich do szpitala, okresowa pomoc pielgrzymom, udział w pogrzebach zmarłych współbraci i podopiecznych szpitala. Ponadto mężczyźni zobowiązani byli do przeprowadzania kwesty i zbiórek pieniędzy na potrzeby szpitala $^{28}$. Bractwa duchackie na Zachodzie, gromadzące świeckich przyjaciół zakonu, zbierały jałmużnę dla biednych $w$ parafiach i rozdzielały ją między potrzebujących, pomagały utrzymywać kościoły, a niekiedy nawet zajmowały się ich budową ${ }^{29}$. Największy rozkwit bractwa nastąpił w XIII i XIV w., zwłaszcza we Włoszech, Francji, Niemczech, a nawet Szwajcarii. Z reguły działały przy licznie powstałych w tych państwach szpitalach duchaków, które bracia obsługiwali. Na Zachodzie, zwłaszcza we Francji, bractwa Świętego Ducha tworzono nie tylko w miastach, ale także na wsiach, gdzie kościoły parafialne formowały u siebie wspólnoty brackie zależne od najbliższego im klasztoru duchaków. Podejmowały one tam dzieło miłosierdzia wśród chorych i biednych, opiekując się potrzebującymi w parafii ${ }^{30}$.

${ }^{26}$ J. Flaga, Bractwa religijne w Rzeczypospolitej, Lublin 2004, s. 214.

${ }^{27}$ K. Antosiewicz, Bractwo Ducha Świętego, jego geneza i rozwój, w: Christianitas et cultura Europae. Księga Jubileuszowa Profesora Jerzego Kłoczowskiego, red. H. Gapski, cz.1, Lublin 1998, s. 43-44; K. Kuźmak, Duch Święty, Bractwa i stowarzyszenia, EK, t. 4, Lublin 1985, kol. 291; Flaga, Bractwa religijne w Rzeczypospolitej, s. 49.

${ }^{28}$ Antosiewicz, Bractwo Ducha Świętego, s. 44; Flaga, Bractwa religijne w Rzeczypospolitej, s. 216.

${ }^{29}$ Bochnak, Religijne stowarzyszenia, s. 52.

${ }^{30}$ Antosiewicz, Bractwo Ducha Świętego, s. 45-46; H. Zaremska, Bractwa w średniowiecznym Krakowie, Wrocław 1977, s. 5-6. 
Konfraternia Świętego Ducha związana z duchakami i ich szpitalami, nie upowszechniła się w Polsce, ponieważ sam zakon, w przeciwieństwie do Zachodu, nie rozwinął się na szerszą skalę w naszych ziemiach i posiadał zaledwie kilka placówek ${ }^{31}$. Występowała ona przy szpitalach i kościołach w Krakowie, Sandomierzu i Kaliszu oraz, co nie do końca jest takie oczywiste, w kilku miejscowościach na Śląsku i Warmii ${ }^{32}$. K. Dola sugerując się informacją, że fratres inserwientes obecni w starych szpitalach w Ścinawie nad Odrą (1209), Chobieni nad Nysą Kłodzką (1223), czy we Wrocławiu (1214), opiekujący się chorymi, wędrowcami i mostami, uważa że byli to bracia zakonu Świętego Ducha ${ }^{33}$. Nie jest to jednak twierdzenie jasne i przekonywujące. Nie wiadomo przede wszystkim, czy autor miał na myśli braci zakonników, czy też członków ewentualnego przyzakonnego bractwa świeckiego. Poza tym istnienie szpitala prowadzonego przez duchaków we Wrocławiu - o czy sam pisze - było hipotetyczne, zwłaszcza w tak wczesnym okresie. Również przybycie tego zakonu do Ścinawy i jej filii w Chobieni datuje się na okres około pięćdziesiąt lat późniejszy. W tym wypadku chodzi być może o zwykłe bractwa szpitalne, a nie zaś o bractwo związane z zakonem duchaków.

Istnieją pewne kontrowersje co do chronologii powstania pierwszego bractwa Świętego Ducha w Polsce. Niektórzy uważają, że działało ono już na początku lub w połowie XIII w. przy szpitalu i kościele Świętego Ducha w Krakowie, w pobliżu świątyni parafialnej Św. Krzyża ${ }^{34}$. Twierdząc, że konfraternia Świętego Ducha została przeszczepiona wraz z zakonem, z którym była związana, niejako utożsamiają czasowo pojawienie się obu tworów na ziemiach polskich. W zasadzie nie można zweryfikować tej tezy, z wyjątkiem informacji podanej przez Pietro De Angelisa, że już w XIII w., do macierzystej konfraterni rzymskiej agregowane zostało bractwo Ducha Świętego w Krakowie ${ }^{35}$. Hanna Zaremska, twierdzi, że konfraternia Świętego Ducha powstała najpóźniej w XV w. i była dziełem biskupa Zbigniewa Oleśnickiego (1423-1455), który erygował ją przy konwencie i szpitalu duchackim, a zarazem przy kościele i parafii Św. Krzyża, pozostającej w ręku zakonu szpitalnego ${ }^{36}$. Pierwsze odnalezione o niej w źródłach informacje pod datą $1456 \mathrm{r} \cdot{ }^{37}$ nie wykluczają jej dużo wcześniejszego rodowodu, jednakże już fakt dokonania erekcji przez Oleśnickiego zawęża potencjalny czas narodzin stowarzyszenia do okresu sprawowania przez niego funkcji biskupiej. Nie można wykluczyć, że bractwo istniało, w niesformalizowany sposób i bez namaszczenia

${ }^{31}$ Flaga, Bractwa religijne w Rzeczypospolitej, s. 124; tenże, Rodzaje, s. 587.

${ }^{32}$ Wiśniowski, Bractwa religijne, s. 62; Kuźmak, Duch Święty, kol. 292; S. Chodyński , Bractwo, w: Encyklopedia Kościelna, t. 2, red. M. Nowodworski, Warszawa 1873, s. 558.

${ }^{33}$ Dola, Szpitale średniowieczne Śląska, s. 246, 282-283, 287.

${ }^{34}$ Kuźmak, Duch Święty, kol. 291-292; Flaga, Rodzaje, s. 587; tenże, Działalność charytatywna bractw religijnych w XVII i XVIII wieku, w: Ecclesia et Status. Księga jubileuszowa z okazji 40-lecia pracy naukowej Profesora Józefa Krukowskiego, red. A. Dębiński, K. Orzeszyna, M. Sitarz, Lublin 2004, s. 388; Kumor, Kościelne stowarzyszenia, s. 519.

${ }^{35}$ P. De Angelis, L'arciconfraternitŕ ospitaliera di Santo Spirito in Saxia, Roma 1950, s. 123. Zob. też Antosiewicz, Bractwo Ducha Świętego, s. 46.

${ }^{36}$ Zaremska, Bractwa, s. 50, 80, 83, 158-159; Litak, Bractwa, s. 505; Litak, Parafie, s. 222.

${ }^{37}$ Zaremska, Bractwa, s. 83. 
biskupiego, w okresie wcześniejszym. Należy brać też pod uwagę ponowną jego reorganizację, odnowę czy nawet erekcję. Wezwanie i nazwa bractwa wiązała się z faktem powołania go przy szpitalu Świętego Ducha, prowadzonym przez zakon duchaków ${ }^{38}$. Po spaleniu krakowskiego szpitala duchaków, bractwo przerwało swoją działalność, wskrzesił je dopiero po odbudowie ks. Saunier ${ }^{39}$.

Przyszpitalna krakowska konfraternia Św. Ducha wyraźnie górowała liczebnością członków nad innymi krakowskimi wspólnotami świeckich. W latach 1540-1543 zarejestrowano w niej 656 osób. Oprócz wiernych z parafii Św. Krzyża, należeli do niej konfratrzy z Kazimierza, Stradomia, Kleparza, Podbrzezia i innych podmiejskich miejscowości, w tym Myślenic i Wieliczki. Ilościowo dominowali przedstawiciele rodzin rzemieślniczych, była też ponad trzydziestoosobowa grupa księży, zdarzali się organiści, dzwonnicy, kościelni. W mniejszej skali szeregi bractwa zasilały osoby ze środowiska szlachecko-dworskiego, a nawet ubodzy. Zwraca uwagę ogromna przewaga kobiet, z których niektóre pełniły funkcje pomocnicze w szpitalu duchaków, np. kucht. W latach 1540-1543 stanowiły one cztery piąte ogółu wpisanych do księgi brackiej. Tak duża liczba kobiet zapisujących się do konfraterni indywidualnie bez swych mężów lub innych członków rodziny wynikała z ich „upośledzonego" statusu społecznego, nieobecności w życiu publicznym i niedostępności do wszelkiego typu instytucji kształcących. Pewne perspektywy aktywności otwierały się dla kobiet w bractwach, które były dla nich organizacjami otwartymi. Aktywność niewiast w bractwach wynikała też ze szczególnych predyspozycji kobiet do angażowania się w ruchy religijne, zwłaszcza charytatywne, wymagające poświęcenia się pracy opiekuńczej na rzecz chorych i ubogich ${ }^{40}$. Bardziej zaskakujące niż feminizacja bractwa świętoduskiego, było zapisywanie do niego przez rodziców swoich nieletnich dzieci $^{41}$. Niewykluczone, że były to gesty symboliczne, wziąwszy pod uwagę że szpitale duchaków, a co za tym idzie i współpracujące z nimi bractwa Ducha Świętego, zawsze kojarzyły się z opieką nad dziećmi, w szczególności porzuconymi; były niejako synonimem opieki nad dziećmi ${ }^{42}$. Do bractwa duchackiego należeli też niektórzy chorzy przebywający w szpitalu Św. Ducha ${ }^{43}$.

Bractwo Ducha Świętego w Polsce spełniało te same funkcje jak w innych krajach; przedmiotem szczególnej troski byli chorzy i biedni oraz osierocone i po-

${ }^{38}$ Tamże, s. 116.

${ }^{39}$ Chodyński, Bractwo, s. 558.

${ }^{40}$ Zaremska, Bractwa, s. 84, 156-157, 159-160, 177.

${ }^{41}$ Tamże, s. 160.

${ }^{42}$ Por. M. Surdacki, Dzieci porzucone w Szpitalu Świętego Ducha w Rzymie w XVIII wieku, Lublin 1998; tenże, Il brefotrofio dell'Ospedale di Santo Spirito in Roma nel XVIII secolo, Conferenze 115, Varsavia-Roma 2002; K. Antosiewicz, Opieka nad dziećmi w zakonie Świętego Ducha w Krakowie (1220-1788), w: Z badań nad dziejami zakonów i stosunków wyznaniowych na ziemiach polskich, red. E. Wiśniowski, Lublin 1984, s. 45-88.

${ }^{43}$ K. Antosiewicz, Opieka nad chorymi i biednymi w krakowskim Szpitalu Świętego Ducha (1220-1741), „Roczniki Humanistyczne”, 26 (1978) z. 2. s. 77. 
rzucone dzieci44, a więc te kategorie osób, które stanowiły „klientelę” szpitali duchackich w Krakowie, Sandomierzu i Kaliszu. Konfratrzy, którzy nie prowadzili krakowskiego szpitala i nie ingerowali w jego wewnętrzne sprawy, udzielali jego ubogim pensjonariuszom pomocy finansowej, solidaryzowali się z nimi, propagując idee dobroczynności. W przeciwieństwie do innych bractw dewocyjnych, a nawet bractw ubogich, w swej pracy zwrócone ku innej społeczności niż własna, „było bractwo Świętego Ducha, wspólnotą, którą określała bardziej chrześcijańska gorliwość niż chęć afirmacji własnej pozycji w mieście ${ }^{45}$.

Skromny stan badań nie pozwala nic więcej powiedzieć o rozwoju i działalności, czy strukturze wewnętrznej bractwa Ducha Świętego w Polsce. Zapewne analogicznie do Europy Zachodniej najlepszy okres, podobnie jak wszystkie szpitale prowadzone przez zakon Świętego Ducha, przeżyło w średniowieczu. Z pewnością działało w Polsce w czasach nowożytnych przy wszystkich trzech polskich szpitalach duchackich. Absolutnym ewenementem było zaprowadzenie bractwa Ducha Świętego w Chronowie w 1638 r. Istnienie bractwa w tej parafii należy traktować jako wyjątek ${ }^{46}$. Ostatecznie konfraternia Ducha Świętego w Polsce przestało istnieć w $1783 \mathrm{r}$. w związku z kasatą zakonu ${ }^{47}$.

Specyficzną grupę, bliską idei bractwa szpitalnego stanowili w XV i XVI w. podopieczni szpitala Sw. Trójcy we Wrocławiu. Owi bracia i siostry - niekiedy ubodzy, często dożywotni prebendariusze, tworząc szpitalną wspólnotę modlitewno-dewocyjną, dbającą o swoje zbawienie, nieśli zarazem pomoc potrzebującym oraz wzajemnie się sobą opiekowali. Społeczność ta choć nie miała charakteru instytucjonalnego tworzyła swego rodzaju bractwo i korporację o znamionach samopomocowych i charytatywnych ${ }^{48}$.

\section{BRACTWA UBOGICH}

W nieco szerszym znaczeniu bractwami szpitalnymi były konfraternie ubogich, rozpowszechnione na ziemiach polskich daleko bardziej od poprzednich. Bractwa ubogich, sporadycznie nazywane bractwami biednych ${ }^{49}$, nastawione wybitnie na działalność społeczno-charytatywną swoim zasięgiem objęły prawie wszystkie ziemie Rzeczypospolitej. Posiadały genezę późnośredniowieczną, a ich największy rozkwit przypadł, mimo ich czternastowiecznych korzeni, przes. 388 .

${ }^{44}$ Flaga, Bractwa religijne w Rzeczypospolitej, s. 216; tenże, Działalność charytatywna,

${ }^{45}$ Zaremska, Bractwa, s. 159.

${ }^{46}$ Flaga, Bractwa religijne w Rzeczypospolitej, s. 124-125; tenże, Rodzaje, s. 587; 320. Artykuł, na który się powołuje J. Flaga, nie wspomina jednak nic o tym bractwie (B. Kumor, Archidiakonat sąecki. Opracowanie materiatów źródłowych do atlasu historycznego Kościoła w Polsce, „Archiwa Biblioteki i Muzea Kościelne” (dalej: ABMK), 9 (1964) s. 320). Istnienia bractwa Św. Ducha w Chronowie nie potwierdzają żadne inne źródła czy opracowania.

${ }^{47}$ Flaga, Bractwa religijne $w$ Rzeczypospolitej, s. 216; tenże, Działalność charytatywna, s. 387.

${ }^{48}$ M. Słoń, Szpitale średniowiecznego Wrocławia, Warszawa 2000, s. 165-166.

${ }^{49}$ Bochnak, Religijne stowarzyszenia, s. 94, 99. Takiej nazwy użył autor w stosunku do bractwa w Szprotawie. 
de wszystkim na XV i początki XVI w. W późniejszym okresie bractwa te stopniowo zanikały, tak że przypadki ich występowania w XVIII w. miały już charakter sporadyczny ${ }^{50}$, a erekcje zupełnie nowych nie miały miejsca. Rozwój bractw ubogich należy rozpatrywać w kontekście rewizji dotychczasowej postawy społecznej czynników kościelno-świeckich w stosunku do biedoty i żebraków, których w przeciwieństwie do średniowiecza, na przełomie tej epoki i czasów nowożytnych, zaczęto postrzegać jako groźną dla porządku społecznego plagę ${ }^{51}$. W niektórych wypadkach stowarzyszano ubogich w osobne bractwa, by uniknąc zgorszeń powodowanych przez żebrzących ludzi ${ }^{52}$. Powstające bractwa dawały możliwość skanalizowania i ujarzmienia pewnej części niewygodnego żywiołu żebraczego, który poprzez akcesję do konfraterni stał się bardziej zdyscyplinowanym i możliwym do skontrolowania. Jako świeckie korporacje miejskie o charakterze dobroczynnym, dostępne dla pewnej części nędzarzy miejskich, ułatwiały jednocześnie czynnikom kościelnym możliwość penetracji środowiska żebraczego oraz roztoczenia nad nim opieki i nadzoru ${ }^{53}$. Nazwa zrzeszenia fraternitas pauperum, złudnie sugerująca jego skład społeczny, w gruncie rzeczy była jedynie dowodem powszechnej akceptacji idei ubóstwa uważanego w średniowieczu za cnotę, a tym samym wszelkiego rodzaju grup pauperes Christi gloryfikowanych w doktrynie religijnej i myśli społecznej czasów przedreformacyjnych ${ }^{54}$.

Bractwa ubogich rozwijały się w miarę równomiernie pod względem chronologii na całości ziem państwa polskiego. Tym niemniej i one nieco wcześniej pojawiły na skrajnie położonych, zachodnio-północnych terenach. Dość licznie powstawały na Pomorzu Zachodnim od początku XIV w. aż do czasów reformacji, zwłaszcza przy drogach pielgrzymkowych i handlowych, w: Gryfinie (1327), Banicach, Goleniowie, Stargardzie (XV w. $)^{55}$. Pierwsze przekazy źródłowe o fraternitates pauperum na Śląsku, kierowanych przez mistrza i seniorów, pochodzą z XV w. Działały one tam m.in. w Jaworze, Środzie i Żmigrodzie, prowadząc przytułki utrzymywane ze składek członków. Problem opieki rozwiązywano w ten sposób, że każdego tygodnia po dwóch członków bractwa zobowiązywało się na zmianę odwiedzać miejscowy szpital ${ }^{56}$.

Konfraternie ubogich mocno rozpowszechnione były na Warmii, popierane głównie przez biskupa Watzelrodego (1497-1513). Spośród istniejących tu 12

${ }^{50}$ Por. Kumor, Kościelne stowarzyszenia, s. 519; Flaga, Działalność charytatywna bractw religijnych w XVII i XVIII wieku, s. 216.

${ }^{51}$ Kumor, Kościelne stowarzyszenia, s. 519.

${ }^{52}$ J. Krętosz, Organizacja archidiecezji lwowskiej obrządku tacińskiego od XV wieku do 1772 roku, Lublin 1986, s. 283.

${ }^{53}$ Zaremska, Bractwa, s. 108; A. Karpiński, Pauperes. O mieszkańcach Warszawy XVI i XVII wieku, Warszawa 1983, s. 328.

${ }^{54}$ H. Zaremska, Bractwa, s. 97; taż, Religijność miejska, w: Kultura Polski średniowiecznej XIV-XV wieku, red. B. Geremek, Warszawa 1997, s. 209-210. Zob. też: Karpiński, Pauperes, s. 322; R. Szczygieł, Lokacja miasta na prawie niemieckim i jego dzieje w czasach jagiellońskich, w: Dzieje Urzędowa, red. R. Szczygieł, M. Surdacki, Lublin-Urzędów 2011, s. 96.

${ }^{55}$ Kumor, Kościelne stowarzyszenia, s. 321; tenże, Kościelne stowarzyszenia, s. 519.

${ }^{56}$ Dola, Szpitale średniowieczne Śląska, s. 245-246. 
miast, w okresie od XIV do początków XVI w. tylko w trzech nie można było stwierdzić ich istnienia ${ }^{57}$. Działały one w Dobrym Mieście (XIV w.), Ornecie (1400), Olsztynie (1476), Jezioranach (1499), Pieniężnie (1554), Barczewie (1565), Braniewie (1573), Bisztynku (1597), Lidzbarku (XVI w.) ${ }^{58}$ oraz Reszlu $(\mathrm{XIV}-\mathrm{XV} \text { w. })^{59}$. Zważywszy, że okres reformacji nie sprzyjał tworzeniu takich organizacji, prawdopodobnie ich początki sięgają czasów wcześniejszych ${ }^{60}$. W połowie XVI w. konfraternie ubogich zaczęły podupadać i biskupi niektóre $\mathrm{z}$ nich włączyli do innych bractw. Bractwo w Olsztynie złączono w 1526 r. z bractwem maryjnym, a w Bisztynku zostało agregowane w 1597 r. do bractwa strzeleckiego $^{61}$. Wizytacja biskupa Marcina Kromera z 1572 r. wymienia je również w niektórych parafiach wiejskich. Głównym celem powstających po wsiach bractw było w tym czasie wzajemne wspieranie się w załatwianiu spraw pogrzebowych. Śladem istnienia tych bractw w diecezji pomezańskiej są postanowienia tutejszego synodu z $1411 \mathrm{r}$. udzielającego 10 dni odpustu wiernym, którzy towarzyszyli zwłokom zmarłych do kościoła i na cmentarz ${ }^{62}$.

Bractw ubogich nie pozbawione były w średniowieczu największe ośrodki miejskie państwa krzyżackiego. Na teren miast pruskich przeniesione zostały z Niemiec, gdzie znane były już na początku XIV w., a może nawet wcześniej (Elendenbruderschafen). Dwie takie wspólnoty istniały w Gdańsku: jedna przy kościele św. Katarzyny (Stare Miasto), druga na terenie Młodego Miasta. Pierwsze o nich wzmianki pochodzą z XV w. Przed 1435 r. powstało bractwo ubogich w Starym Mieście Toruniu. Takie same stowarzyszenie działało też w Nowym Mieście Toruniu. W pewnym momencie doszło do połączenia obu wspólnot, bowiem w 1519 r. istniała już jedna taka korporacja dla całego miasta. Również dwa bractwa ubogich erygowano w Elblągu: w Nowym Mieście - przed 1402 r., zaś staromiejskie przed $1481 \mathrm{r}$. Confraternitas miserorum działało też w Tczewie, i choć pierwsza wzmianka o nim pochodzi dopiero z 1597 r., to jednak musiało ono mieć dużo wcześniejszy rodowód. Prawdopodobnie podobnych organizacji na tych terenach było więcej ${ }^{63}$. Zdaniem I. Czarcińskiego, erygowanie niemal w każdym ośrodku państwa krzyżackiego bractw ubogich należy interpretować nie tyle jako miłosierny akt wobec ubogich, lecz przede wszystkim jako chęć roztoczenia przez władze miejskie opieki i nadzoru nad środowiskiem ubogich ${ }^{64}$. Podobną strategię przypisuje akcji zakładania tych konfraterni w diecezji krakow-

${ }^{57}$ Wiśniowski, Bractwa religijne, s. 56, 58.

${ }^{58}$ A. Kopiczko, Ustrój i organizacja diecezji warmińskiej w latach 1525-1772, Olsztyn 1993, s. $226-229$.

${ }^{59}$ Kumor, Kościelne stowarzyszenia, s. 222.

${ }^{60}$ Wiśniowski, Bractwa religijne, s. 58. Np. bractwo w Barczewie w 1565 r. określono już jako stare (Kopiczko, Ustrój i organizacja, s. 229.)

${ }^{61}$ Kopiczko, Ustrój i organizacja, s. 229. Bractwo w Jezioranach upadło w 1597 r., a w Lidzbarku w XVI w.

${ }^{62}$ Wiśniowski, Bractwa religijne, s. 58-59.

${ }^{63}$ Czarciński., Bractwa, s. 50, 55, 105-106.

${ }^{64}$ Tamże, s. 106 
skiej biskupowi Zbigniewowi Oleśnickiemu ${ }^{65}$. Nie odmawiając po części racji takiej ocenie, wydaje się, że jest ona zbyt radykalna i jednoznaczna. Nie ma żadnych dowodów, by w epoce gloryfikacji ubóstwa i nobilitacji ubogiego w średniowiecznej doktrynie Kościoła, biskupi erygując konfraternie zrzeszające biedaków kierowali się wyłącznie pragmatyzmem a nie chrześcijańskim miłosierdziem.

W diecezji kamieńskiej w okresie od XIV w. do czasów reformacji źródła stwierdzają 45 korporacji ubogich $^{66}$. Także w diecezji chełmińskiej bractwa ubogich pojawiły się już w XIV i XV w. Do najstarszych należały w Toruniu, Grudziądzu, Kościerzynie (1406), Koronowie (przed 1596) i Tczewie. W 1341 r. zostało erygowane na Helu zaliczane do ubogich bractwo św. Katarzyny, którego celem było ratowanie tonacych na morzu. W XIV-XV w. prawdopodobnie powstało bractwo ubogich św. Łazarza w Tucholi67. W archidiecezji gnieźnieńskiej bractwa ubogich bardzo często związane były ze szpitalami, istniały w Lutomiersku (1503), Łeknie, Łowiczu (przed 1557), Pajęcznie (przed 1607). W diecezji włocławskiej wizytacje kościelne $\mathrm{z}$ lat 1584-1598 informują o istnieniu tychże bractw w Brdowie, Izbicy, Kowalach, Nowej Cerkwi, Raciążu, Służewie, Śmiłowicach $^{68}$.

$\mathrm{Na}$ ziemiach rdzennie polskich bractwa ubogich najwcześniej pojawiły się w Krakowie. Jako pierwsze bractwo - fraternitas pauperum seu mendicorum biskup Zbigniew Oleśnicki erygował w 1433 r. przy kościele Wszystkich Świętych. Po nim, w 1484 r., powstała analogiczna konfraternia przy kościele św. Jakuba w Kazimierzu, zaś dwa kolejne w 1501 r. przy kościołach św. Floriana (Ubóstwa Chrystusowego - Paupertatis Christi) i św. Mikołaja (przed 1598) - oba na Kleparzu. Wszystkie wymienione stowarzyszenia ubogich, założone przy świątyniach parafialnych, działały w czasach wizytacji biskupa Jerzego Radziwiłła z 1598 r. $^{69}$.

Konfraternie ubogich szerzyły się również w całej diecezji krakowskiej, propagowane usilnie w XV w. przez biskupa Zbigniewa Oleśnickiego. Dokonał on erekcji bractw ubogich przy kościołach parafialnych w Borzęcinie, Koprzywnicy, Łękawicy (1448), Porąbce Uszewskiej, Szczepanowie, Wojniczu, Szczurowej, Jadownikach, Skaryszewie i Żarnowcu ${ }^{70}$. Z nieco późniejszego okresu datują się te

${ }^{65}$ Zobacz niżej (rozważania o bractwach ubogich w diecezji krakowskiej).

${ }^{66}$ Wiśniowski, Bractwa religijne, s. 58

${ }^{67}$ Diecezja chetminska. Zarys historyczno-statystyczny, Pelplin 1928, s. 81; Litak, Bractwa, s. 503; tenże, Parafie, s. 220; Kumor, Kościelne stowarzyszenia, s. 322.

${ }^{68}$ Kumor, Kościelne stowarzyszenia, s. 322; tenże, Kościelne stowarzyszenia, s. 520.

${ }^{69} \mathrm{H}$. Zaremska, Żywi wobec zmartych. Brackie i cechowe pogrzeby w Krakowie w XIV-pierwszej połowie XVI wieku, „Kwartalnik Historyczny”, 81 (1974) nr 4, s. 236-237; Zaremska, Bractwa, s. 50, 79-80, 87, 92, 107, 175-176: P.P. Gach, Bractwa kościelne w Krakowie pod koniec XVI wieku, „Sprawozdania Tow. Naukowego KUL”, 18 (1969) s. 131-132; Litak, Bractwa, s. 505.

${ }^{70}$ Zaremska, Bractwa, s. 107; B. Kumor, Prepozytura tarnowska, Opracowanie materiałów źródłowych do atlasu historycznego Kościoła w Polsce, ABMK, 12 (1966) s. 237; Litak, Bractwa, s. 505. (Bractwa w Koprzywnicy, Żarnowcu i Skaryszewie Litak wymienia jako bractwo ubogich, Zaremska nie). 
organizacje w Mogile (1495) i z końca XVI w. w Lublinie ${ }^{71}$. Ewenementem było bractwo w parafii wiejskiej Łękawica, na terenie prepozytury tarnowskiej. Istniała tam jeszcze druga taka konfraternia w mieście Dąbrowa Tarnowska, erygowana przez biskupa Piotra Tomickiego w 1537 r., a zanikła przed 1596 r. ${ }^{72}$ Stosunkowo późno, bo w 1602 r., biskup Bernard Maciejowski zatwierdził kolejne bractwo ubogich w tym regionie, w Zwierniku na terenie dekanatu pilzneńskiego ${ }^{73}$. Takie samo bractwo istniało też w $1596 \mathrm{r}$. w parafii Bolesław należącej administracyjnie do prepozytury wiślickiej ${ }^{74}$.

W bardzo dobrze przebadanym archidiakonacie lubelskim, leżącym w północno-wschodniej części diecezji krakowskiej, funkcjonowało na przełomie XV i XVI w. siedem kontuberni ubogich. Najstarsza w Siennie pod wezwaniem św. Katarzyny z Góry Synaj, zatwierdzona została w 1492 r. W 1505 r. aprobatę biskupią uzyskała wspólnota ubogich w Chodlu. Pierwsze informacje źródłowe o pięciu kolejnych takich stowarzyszeniach - w Biskupicach, Kazimierzu, Lublinie, Łęcznej i Michowie - pochodzą dopiero z wizytacji odbytej w 1603 r. Z pewnością ich rodowód był jednak dużo wcześniejszy. Bractwa ubogich były najliczniejsze spośród wszystkich istniejących na tym terenie bractw religijnych. Jedna tego typu konfraternia przypadała tam średnio na nieco więcej niż dziesięć parafii. Wszystkie posiadały charakter miejski, i z wyjątkiem bractwa lubelskiego przy klasztorze brygidek, działały w oparciu o kościoły parafialne ${ }^{75}$. Bractwo przybrygidkowskie miało za cel niesienie pomocy materialnej i moralnej ludziom ubogim, mieszkającym zwłaszcza na przedmieściu i w dobrach ziemskich klasztoru. Mocno zaniedbane pod koniec XVI w., zostało odnowione i zatwierdzone w 1604 r. przez legata papieskiego Klaudiusza Rangoniego. Mocą jego pisma, w kościele brygidek, w którym wcześniej istniał zakaz uprawiania muzyki, ze względu na istnienie bractwa ubogich, zezwolono w przyszłości grać na organach. Klasztor usilnie popierał stowarzyszenie. W $1603 \mathrm{r}$. wydał przywilej lokacyjny jurydyki Panny Maryi, zobowiązujący tam mieszkających do wstępowania do bractwa ubogich i utrzymywania $\mathrm{go}^{76}$. $\mathrm{Z}$ terenu Lubelszczyzny znane jest jeszcze bractwo ubogich w Urzędowie, po raz pierwszy odnotowane w 1585 r. choć utworzone zapewne $\mathrm{w} \mathrm{XV} \mathrm{w.}{ }^{77}$ Brak śladów istnienia wymienionych bractw w późniejszych dziesięcioleciach XVII w. i w następnym stuleciu oraz niewprowadzanie nowych

${ }^{71}$ Kumor, Kościelne stowarzyszenia, s. 322; J.A. Wadowski, Kościoły lubelskie, Lublin 2004 , s. 440.

${ }^{72}$ Kumor, Prepozytura, s. 225, 237; S. Litak, Struktura terytorialna Kościoła łacińskiego w Polsce w 1772 roku, Lublin 1980, s. 209.

${ }^{73}$ Kumor, Archidiakonat sadecki, s. 227.

${ }^{74}$ Funkcjonowało ono jeszcze prawdopodobnie w 1748 r. Zob. E. Wiśniowski, Prepozytura wiślicka do schytku XVIII wieku, Lublin 1976, s. 172, 179.

${ }^{75} \mathrm{~J}$. Flaga, Bractwa religijne w archidiakonacie lubelskim do początku XVII wieku, „,Roczniki Humanistyczne", 21 (1973) z. 2, s. 152-153-158, 166; tenże, Bractwa religijne $w$ archidiakonacie lubelskim do końca XVIII wieku., ABMK, 42 (1981) s. 302, 304, 306, 316, 318, 320, 324, 328, 330, 337.

${ }^{76}$ Wadowski, Kościoty, s. 440-441.

${ }^{77}$ Szczygieł, Lokacja miasta, s. 95-96. 
wskazuje, że przynajmniej na tym terenie, były one typowe dla okresu wcześniejszego $^{78}$. Jeśli gdzieś nadal funkcjonowały, to na zasadzie pewnego wyjątku. Dwa bractwa ubogich, jakie istniały w połowie XVIII stulecia w liczącej około 900 parafii diecezji krakowskiej, były pozostałością z dawnej epoki ${ }^{79}$.

Bractwo ubogich szeroko rozpowszechniło się w całej diecezji poznańskiej, głównie w miastach. Na terenie tej diecezji odnotowano istnienie 29 konfraterni ubogich, w większości związanych ze swoimi altariami. Dwie trzecie z nich posiadało XV-wieczny rodowód, przeważnie z około połowy tego stulecia. Najstarsze znane było w $1440 \mathrm{w}$ Krobi. Jedynie w Pniewach bractwo posiadało nieco późniejszy rodowód, ponieważ jego zatwierdzenie wraz ustawami miało miejsce w 1611 r., co sugeruje, że mogło powstać dopiero u progu XVII w. ${ }^{80}$ Bractwo to popularne tam było jeszcze nawet $\mathrm{w}$ XVIII w. ${ }^{81}$ Dwa $\mathrm{z}$ nich prowadzone przez jezuitów dotrwały aż do $1772 \mathrm{r}^{82}$

Prawie nic nie można powiedzieć na temat ewentualnego istnienia konfraterni ubogich na Mazowszu, z wyjątkiem Mławy, w której bractwo takie odnotowują akta wizytacji biskupa Wojciecha Baranowskiego z przełomu XVI/XVII w. Posiadało ono swój ołtarz w kaplicy Sławogórskich z obrazem patrona biedaków św. Mikołaja $^{83}$. Na pewno żadnej konfraterni ubogich nie stwierdzono na terenie diecezji płockiej w drugiej połowie XVIII w. ${ }^{84}$, nie było ich tam też w okresie XVIIXVIII w. we wschodniej enklawie diecezji poznańskiej, archidiakonacie warszawskim z wyjątkiem Warszawy ${ }^{85}$. W przyszłej stolicy eksponowane miejsce

${ }^{78}$ Flaga, Bractwa religijne $w$ archidiakonacie lubelskim do końca XVIII wieku, s. 329-330. Ostatnie wzmianki źródłowe o bractwach ubogich w Chodlu i Kazimierzy pochodzą z 1611 r., zaś o bractwie lubelskim z 1650 r. (tenże, s. 305, 307, 316).

${ }^{79}$ Flaga, Rodzaje, s. 587; tenże, Bractwa religijne w archidiakonacie lubelskim do końca XVIII wieku, s. 330; tenże, Bractwa religijne w Rzeczypospolitej, s. 125

${ }^{80}$ Istniały one w następujących miastach: Krobia (1440), Poniec (1446), Śrem (1447), Poznań - św. Marcina (przed 1449), Wschowa (przed 1450), Krzywin (1450), Dolsk (1456), Miejska Górka 1456), Osieczna (1458), Gostyń 1460), Zaniemyśl (przed 1461), Kaźmierz (1465), Strzelce Wielkie (1465), Borek (1467), Niepart 1468), Święciechowa (1472), Chodzież (1474), Oborniki (1495), Międzyrzecz (1496), Zbąszyń (przed 1497), Kórnik (1506), Grodzisk (przed 1510), Jarocin (5013), Skwierzyna (1513), Wolsztyn (1513), Rogoźno (1525), Środa (przed 1607), Pniwey (przed 1611), Pyzdry (przed 1624). J. Nowacki, Dzieje archidiecezji poznańskiej, t. 2: Archidiecezja poznańska w granicach historycznych i jej ustrój, Poznań 1964, s. 744-745. S. Litak (Parafie, s. 225, Bractwa, s. 507) wyliczył na podstawie pracy Nowackiego 19 konfraterni ubogich. Z kolei E. Wiśniowski mówi o 26 takich konfraterniach (Bractwa religijne, s. 58), zaś A. Weiss o 31 (Poznańska diecezja, EK, t. 16, Lublin 2012, kol. 193)

${ }^{81}$ Nowacki, Dzieje archidiecezji, s. 744.

82 J. Flaga, Bractwa i sodalicje jezuickie w Polsce w 2 połowie XVIII wieku, „Summarium”, 3 (23), 1974, s. 1974, s. 146.

${ }^{83}$ Zygner, Działalność misjonarzy św. Wincentego a Paulo, s. 147-148; D. Staszewski, Mława, Opis historyczny, Warszawa 1907, s. 46.

${ }^{84} \mathrm{~J}$. Flaga, Bractwa i przejawy życia religijnego w 2 połowie XVIII wieku, „Roczniki Humanistyczne", 24 (1976) z. 2, s. 35-67.

${ }^{85} \mathrm{~J}$. Szwed, Bractwa religijne $w$ archidiakonacie warszawskim $w$ XVII $i$ XVIII w., Lublin 2002 (mps, Archiwum KUL). 
zajmowało bractwo ubogich założone w latach 1545-1546 przy kolegiacie św. Jana w Warszawie. W latach 1624-1625 wielka epidemia dżumy praktycznie unicestwiła działalność konfraterni. Erygował ją ponownie w 1646 r., za zgodą biskupa poznańskiego Andrzeja Szołdrskiego, wikariusz kolegiaty warszawskiej ksiądz Adam ze Słupska ${ }^{86}$.

Na ziemiach wschodnich Rzeczypospolitej, słabiej zurbanizowanych, gdzie organizacja kościelna, diecezjalna i parafialna oraz zakony rozwinęły się w okresie późniejszym, również bractwa pojawiły się odpowiednio później i mniej licznie ${ }^{87}$. Stwierdzenie to tyczy w szczególności bractw charytatywnych, w tym konfraterni ubogich, które w przeciwieństwie do terenów dotąd analizowanych, stanowiły na wschodzie zjawisko bardzo rzadkie. Pewnym wyjątkiem była buforowo położona diecezja przemyska, w której istniało 10 bractw ubogich, w: Przemyślu - przy katedrze (1502), Soli (1502), Radymnie (1520), Jarosławiu (1523), Sanoku (1533), Samborze (1547), Krośnie (1597- raczej pocz. XVI w) oraz w Łańcucie, Mościskach, Przeworsku. Wszystkie miały charakter miejski i powstały nieco później niż analogiczne bractwa na ziemiach centralno-zachodnich. Można przypuszczać, że przynajmniej kilka bractw, o których podane wyżej pierwsze informacje pochodzą z XVI w., mogło powstać jeszcze w poprzednim stuleciu. W wypadku bractw w Soli i Przemyślu ich rodowód przynajmniej ze schyłku XV w. jest niemal stuprocentowo pewny. To samo tyczy się bractwa w Radymnie, które już w 1520 r. określane było jako starożytne ${ }^{88}$. Z wyjątkiem krośnieńskiego, w drugiej połowie XVI w. nie powstało w tej diecezji żadne nowe bractwo. Zjawisko to łączyć można z rozwojem reformacji protestanckiej na tym terenie, która czyniła tu znaczne postępy. W XVIII stuleciu liczba czynnych Bractw Ubogich skurczyła się do dwóch (Przemyśl, Krosno). Pozostałe zanikły pod wpływem bliżej nieokreślonych przyczyn. Być może stało się to za sprawą rozwijających się bujnie w XVII i XVIII w. przytułków dla ubogich - szpitali ${ }^{89}$. Opinię tę można zresztą odnieść i do innych terenów Rzeczypospolitej.

We Lwowie, w którym działało do końca XVIII w. kilkanaście typów bractw, jednym z najwcześniejszych było Confraternitas Pauperum, założone w 1442 r. przy katedrze, a odnowione w 1597 r. jako Confraternitas Misericordiae. Istniało ono w nowej postaci do XVIII w. W mieście tym, przy kościele NMP Śnieżnej powstało w 1627 r. drugie bractwo ubogich, zaś na terenie całej archidiecezji lwowskiej działały jeszcze konfraternie ubogich w: Dunajowie, Bruchnalu, Bóbrce, Komarnie, Żydaczowie, erygowane w latach $1482-1498^{90}$.

${ }^{86}$ A. Karpiński, Pauperes, s. 322-323, 328; J. Łukaszewicz, Krótki opis historyczny kościołów parochialnych, kościołów, kaplic, klasztorów, szkółek parochialnych, szpitali i innych zakładów dobroczynnych dawnej diecezji poznańskiej, t. 1, Poznań 1958, s. LXVIII.

${ }^{87}$ Litak, Parafie, s. 225; tenże, Bractwa, s. 509.

${ }^{88} \mathrm{H}$. Borcz, Bractwa religijne w kościołach parafialnych diecezji przemyskiej w okresie przedrozbiorowym, „Roczniki Teologiczno-Kanoniczne”, 28 (1981) z. 4, s. 78-82, 84, 89. Inny autor bardziej wiarygodnie podaje, że konfraternia w Krośnie funkcjonowała od początku XVI w.: Budzyński, Dzieje opieki, s. 58, 158. Bractwo w Przemyślu działało przy katedrze (Kumor, Kościelne stowarzyszenia, s. 322).

${ }^{89}$ Borcz, Bractwa religijne, s. 85-86.

${ }^{90}$ Krętosz, Organizacja, s. 275, 281-283. 
Konfraterni ubogich pozbawiona była diecezja wileńska, za wyjątkiem samego Wilna, w którym założone w 1636 r. przy kościele św. Jana „bractwo ubogich czyli Miłosierdzia" doskonale obrazuje strukturę i specyfikę tego typu organizacji. Bractwo zwane też stowarzyszeniem lub cechem dziadów wileńskich, w czasie wizytacji z $1784 \mathrm{r}$ nie prowadziło własnego szpitala, nie posiadało też żadnego funduszu, mimo że wcześniej dysponowało kapitałem 5.000 zł., z którego proboszcz ubogim prowizje wydawał. Zrzeszało około 350 ubogich znajdujących się w szpitalach i gospodach całego Wilna, w tym 40 biednych osób obojga płci skupionych przy wspomnianym kościele, żyjących z jałmużny przykościelnej oraz z kwestowania po mieście ${ }^{91}$.

Nic nie wskazuje by konfraternie ubogich występowały w peryferyjnych diecezjach wschodnich: kamienieckiej ${ }^{92}$, żmudzkiej ${ }^{93}$, łuckiej ${ }^{94}$. Przedstawiona wyżej lista ośrodków działania bractw ubogich nie jest kompletna, niemniej widać z niej, że instytucja ta objęła prawie wszystkie ziemie Rzeczypospolitej ${ }^{95}$.

Bractwa ubogich dostępne dla wszystkich mieszkańców miasta, zrzeszały $\mathrm{w}$ swych szeregach również ubogich $\mathrm{z}$ najniższych warstw społecznych, ludzi pozostających poza systemem cechowo-korporacyjnym, kontrolowanym przez samorząd miejski. Tego typu bractwa były jedynymi organizacjami dostępnymi dla żyjących w średniowiecznej społeczności miejskiej czy parafialnej przedstawicieli środowisk nędzy. Przyjmując do swego grona biedaków zobowiązywały się bractwa do służenia im pomocą i wspierania finansowego ${ }^{96}$. Roztaczały opiekę zwłaszcza nad miejscowymi ubogimi, ale także niekiedy nad obcymi przybyszamiiwędrowcamipotrzebującymi wsparcia ${ }^{97}$. W statutach korporacjiubogich w wielkopolskim Jarocinie z 1513 r. wyraźnie podkreślono, ,że w bractwa te zrzeszano pod przewodnictwem plebana, burmistrza i zamożniejszych obywateli ludzi prawdziwie ubogich, którzy nie mieli warunków należenia do bractw cechowych lub innych"98.

Przykład krakowskich konfraterni ubogich, przynajmniej bractwa przy kościele św. Floriana na Kleparzu, wskazuje, że ich struktura społeczna była po części elitarna. W gronie członków, którzy w latach 1501-1550 zapisali się do tej konfraterni (w sumie 1303 osoby) dominowali rzemieślnicy i członkowie cechów krakowskich (ok. 60\%). Spory udział w stowarzyszeniu mieli dostojnicy miejscy

${ }^{91}$ J. Kurczewski, Biskupstwo wileńskie, Wilno 1912, s. 364.

${ }_{92}$ J. Flaga, Bractwa religijne $w$ diecezji kamienieckiej w połowie XVIII wieku, w: Religie. Edukacja. Kultura, Księga pamiątkowa dedykowana profesorowi Stanisławowi Litakowi, red. M. Surdacki, Lublin 2002, s. 611-621; B. Kumor, Kamieniecka diecezja, EK, t. 8, Lublin 2000, kol. 463.

${ }^{93} \mathrm{~J}$. Flaga, Informacje o bractwach religijnych $w$ relacji biskupa żmudzkiego Antoniego Tyszkiewicza z roku 1748, „Sprawozdania Towarzystwa Naukowego KUL”, 20 (1973) s. 42-47.

${ }^{94}$ L. Królik, Organizacja diecezji tuckiej i brzeskiej od XVI do XVIII wieku, Lublin 1983, s. 336-337.

${ }^{95}$ Kumor, Kościelne stowarzyszenia, s. 322; tenże, Kościelne stowarzyszenia, s. 520.

${ }^{96}$ Zaremska, Bractwa, s. 108; taż, Religijność miejska, s. 23; Krętosz, Organizacja, s. 283; Czarciński, Bractwa, s. 106.

${ }^{97}$ Wiśniowski, Bractwa religijne, s. 58.

${ }^{98}$ Nowacki, Dzieje archidiecezji, s. 744. 
ze środowiska urzędniczego - ławnicy, rajcy, a także kapłani (ci ostatni ponad 2\%). Zdecydowanie mniejszościową grupą w bractwie, wynoszącą niewiele ponad $8 \%$ zarejestrowanych, byli sami ubodzy. Już jednak sam fakt, jak pisze H. Zaremska, współżycia „rządców” Kleparza i jego ubogich wskazuję na pewną koncepcję zajęcia się ,parafialną biedotą”. Dzięki korporacyjnej przynależności pauperes włączani byli w religijny nurt życia parafii, uczestniczyli w jej uroczystościach i świętach, odpłatnie zatrudniani byli do najrozmaitszych posług w czasie pogrzebów czy procesji, uzyskując przez to jakieś środki do życia ${ }^{99}$. Na uwagę zasługuje, praktykowany w kleparskim Bractwie Ubóstwa Chrystusowego, zwyczaj równoczesnego wstępowania do organizacji chlebodawcy wraz z zatrudnionymi przez niego osobami. Była to konfraternia o zrównoważonej strukturze pod względem płci, w którym liczba kobiet odpowiadała mniej więcej liczbie męż$\operatorname{czyzn}^{100}$. Podobny do bractwa przy św. Florianie był również skład społeczny warszawskiej konfraterni ubogich. W latach czterdziestych XVII w. należeli do niej raczej ludzie majętni, rekrutujący się z różnych środowisk społecznych. Obok licznych duchownych, spotkać tam można było wielu przedstawicieli zamożnej szlachty i magnaterii. Największa jednak część członków organizacji pochodziła $\mathrm{z}$ dostatnich stołecznych rodzin mieszczańskich. Tak więc dominujące ilościowo w konfraterni środowisko ludzi z wyższych warstw społecznych Warszawy, utrzymywało ciężar opieki nad drugim biegunem stowarzyszenia, który stanowili miejscowi żebracy spod kościoła św. Jana ${ }^{101}$.

Ekskluzywny charakter dwóch wymienionych „,wielkomiejskich” korporacji ubogich burzy niejako dotychczasowe wyobrażenie o strukturze społecznej tych bractw, które według niektórych badaczy, zrzeszały przede wszystkim najniższe warstwy społeczne, między innymi żebraków i pensjonariuszy szpitali ${ }^{102}$. Jeden $\mathrm{z}$ nich twierdził nawet, że Confraternitas miserorum stworzone zostały po prostu dla ubogich ${ }^{103}$. Możliwe, że taką specyfikę społeczną posiadały bractwa w mniejszych miasteczkach. Kontestowanie jednak protekcyjno-opiekuńczej polityki tychże bractw w stosunku do własnego i lokalnego środowiska żebraków, oraz twierdzenie, że główna misja tych organizacji polegała na trosce o „obcych” w mieście i wędrujących pielgrzymów, jest w stosunku do ziem rdzennie polskich nieuprawnione ${ }^{104}$. Przeczą temu zachowane statuty niechętnie odnoszące się do przybyłych żebraków, z reguły pozostających poza strukturami korporacji. Statut bractwa wileńskiego z 1636 r. regulował życie codzienne i sposób zachowania się ubogich, tak brackich, jak i zewnętrznych. Przybywający do Wilna żebracy i pielgrzymi, pomimo posiadania zaświadczeń i listów polecających, musieli wpierw zgłosić się do gospody ubogich, by stamtąd uzyskać zgodę na korzystanie z jałmużny. Mogli oni kwestować w stolicy diecezji, i to za pisemnym pozwoleniem magistratu, co najwyżej trzy dni, po którym to terminie musieli opuścić miasto.

\footnotetext{
${ }^{99}$ Zaremska, Bractwa, s. 93-96, 108.

100 Tamże, s. 158-162.

${ }^{101}$ Karpiński, Pauperes, s. 325.

${ }^{102}$ Wiśniowski, Bractwa religijne, s. 58, 66; Zaremska, Bractwa, s. 108.

${ }^{103}$ Diecezja chetmińska, s. 81.

${ }^{104}$ Czarciński, Bractwa, s. 21-22.
} 
Władze bractwa natomiast, przy współpracy z władzami miejskimi, starały się kontrolować i ewidencjonować własne środowisko ubogich i żebraków. Czyniły to za pośrednictwem biczowników brackich, którzy dokonując rewizji miasta i lustracji jego ulic, ściągali do gospody i wpisywali do rejestru w księgach imiona wszystkich tułających się prawdziwie ubogich. Napotkanych ubogich „bez stancji” lub leżących pod murem, umieszczali w miejscowym szpitalu św. Nikodema. Zarejestrowani ubodzy lub pensjonariusze szpitalni otaczani byli opieką bracką, posiadali pewne prawa, np. przywilej sobotniego żebrania, ale i obowiązki. Ubodzy szpitalni mogli legalnie siedzieć po ulicach i żebrać, jednakże w wyznaczone tylko dni, w wielki post, święta Wielkanocne, tydzień przed Wszystkimi Świętymi i na Boże Narodzenie. Generalnie „wszyscy w mieście Wilnie, na przedmieściach i w Polu na gościńcach po budach mieszkający mieli być posłuszni bractwu". Ich zachowanie kontrolowali biczownicy, posiadający obowiązek wypędzania z miasta nierejestrowanych i wszczynających tumulty żebraków. W wypadku, gdy nie radzili sobie z ,poskromnieniem” żywiołu żebraczego, mogli korzystać z pomocy władz miejskich - wójta i burmistrzów, mających prawo „zabrania" włóczęgów i karania ich plagami ${ }^{105}$.

Istnieją przesłanki sugerujące, że w pierwotnej idei bractwa ubogich w swej strukturze członków nie były tak zdominowane przez środowiska pozażebracze, a przynajmniej niektóre z nich. Na przykład w Krośnie, w przeciwieństwie do innych ośrodków miejskich, późnośredniowieczna konfraternia ubogich była rzeczywiście zawodową organizacją i wspólnotą, obejmującą jedynie żebraków żyjących przy kościele farnym, kierowaną przez plebana. Dopiero w 1595 r. Feliks de Valle, miejscowy pleban i kanonik przemyski, przeprowadził reorganizację bractwa, włączając do niego - na wzór konfraterni w innych miastach - przedstawicieli władz miejskich i mieszczan, a jednocześnie podporządkował mu wszystkich żebraków krośnieńskich ${ }^{106}$.

Ograniczona partycypacja biedoty w bractwach, tworzonych z myślą zapewnienia jej wielorakiej pomocy, wynikała z samych statutów i regulaminów korporacyjnych. Elitarny i zamknięty charakter zgromadzonych przy bractwie nędzarzy podkreśla statut konfraterni warszawskiej z 1646 r., zabraniający pod karą wygnania z miasta, proszenia jałmużny przed kolegiatą św. Jana żebrakom będącym poza korporacją. Przywilej korzystania z pomocy bractwa dotyczył wyłącznie osób w nim stowarzyszonych, a dokładnie dziadów żebrzących pod kolegiatą świętojańską, i to tylko tych, których uznano za godnych pomocy. Dlatego też, każdy żebrak chcąc legalnie żebrać zobowiązany był zgłosić się do kościelnych brackich, którzy po zweryfikowaniu autentyczności jego ubóstwa oraz stwierdzeniu niezdolności do pracy, wpisywali go do stowarzyszenia i wyznaczali odpowiednie miejsce przy wymienionej świątyni ${ }^{107}$. Żebracy nie mogli jednak otwierać puszek z zebraną jałmużną i przeznaczać jej dla siebie. Była ona własnością wspólną, którą władze zwierzchnie dzieliły w miarę równo między wszystkich

\footnotetext{
${ }^{105}$ Kurczewski, Biskupstwo, s. 365-366.

${ }^{106}$ Budzyński, Dzieje opieki, s. 58, 157-158.

${ }^{107}$ Karpiński, Pauperes, s. 323.
} 
podopiecznych ${ }^{108}$. Identyfikację członków bractwa uprawnionych do żebrania ułatwiały specjalne znaki, tzw. blachy, przytwierdzane do czapek lub ubrań na wysokości piersi ${ }^{109}$. Były one widomym znakiem legalności uprawianego przez nich procederu ${ }^{110}$. Prawo do legalnego kwestowania i zbierania jałmużny, a także zwolnienia z różnych obowiązków na rzecz miasta, dawało zrzeszonym w bractwie na tyle duże korzyści, że za wszelką cenę starali się bronić jego wyłączności. Żebracy bractwa krośnieńskiego solidarnie występujący w obronie tego monopolu, starając się przede wszystkim usuwać z miasta intruzów, zdołali utrzymać go aż do czasów austriackich ${ }^{111}$. Władze bractw gwarantując swoim członkom prawo do żebrania, walczyły jednocześnie z tzw. fałszywymi żebrakami Toteż biczownicy $z$ konfraterni wileńskiej mieli wypędzać $z$ miasta biednych ale młodych żebraków, nie chcących podjąć pracy, a innych swawolnych, nieposłusznych i pozorujących ułomność, zgłaszać starszym i karać rózgami bądź karcerem. Mieli również zabraniać proszenia o jałmużnę chłopcom przybywającym ze wsi, ani pozwalać by wodzili oni po mieście ślepców. Tych ostatnich prowadzać miał jeden z chromych lecz widzących żebraków ${ }^{112}$.

Przyjęcia nowych członków odbywały się na wspólnych zebraniach, tzw. schadzkach ${ }^{113}$. W krakowskim bractwie ubogich przy kościele Wszystkich Świętych zgody na akcesję do wspólnoty udzielał proboszcz ${ }^{114}$. Przystąpienie do bractwa wiązało się z obowiązkiem uiszczenia przez kandydata wpisowego, inaczej opłaty wstępnej. $Z$ uwagi na niski status społeczny i materialny członków bractwa wywodzących się z niższych warstw społecznych lub stanu żebraczego, przy akcesji do stowarzyszenia w Jarocinie zwalniano tych nowicjuszy $\mathrm{z}$ opłat wstępnych. W zamian za to przyszli konfratrzy mieli odmawiać pacierze i modlitwy oraz zobowiązani byli do „umiłowania ubóstwa i wspierania prawdziwie ubogich" i chorych pensjonariuszy w szpitalach i przytułkach, z którymi bractwa te były związane ${ }^{115}$. Żebracy we własnym interesie starali się ograniczać wzrost liczebny wspólnoty, do której - ze względu jej intratność i szczególne przywileje - ciągnęło wielu ubogich utrzymujących się z jałmużny. Z tego też względu, w bractwie krośnieńskim, zgodnie ze statutem z 1595 r., wpisowe dla tych kategorii członków było dwukrotnie wyższe niż dla pozostałych, i wynosiło w końcu XVI w. 12 gr. ${ }^{116}$. Można powiedzieć, że sprzeniewierzało się to pierwotnej charytatywnej idei tych bractw, z założenia ukierunkowanych na najuboższych. Przytoczone wyżej przykłady pokazują też, że w kwestii wpisowego nie stosowano wspólnych i jednolitych zasad, a jego wysokość i kryteria egzekwowania zależały od lokalnych uwarunkowań oraz statutów i polityki poszczególnych bractw. Ge-

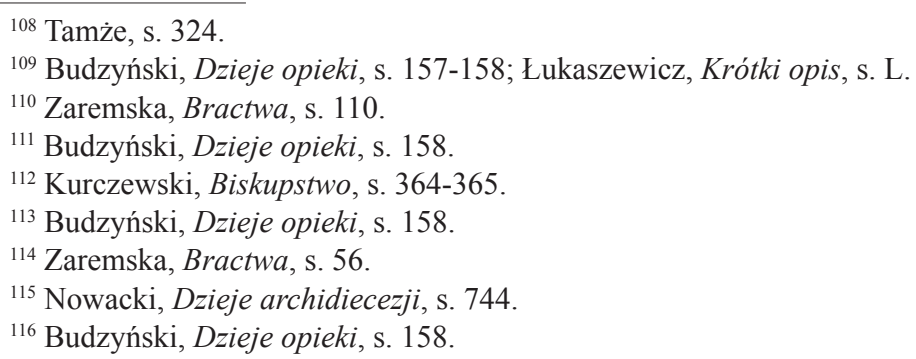


neralnie jednak ulgi w opłatach wstępnych były zwyczajem we wszystkich konfraterniach dewocyjnych ${ }^{117}$, toteż trudno przypuszczać, by nie stosowano ich w większości bractw przeznaczonych dla najuboższych.

Bractwa sprawowały pełną kontrolę nad życiem każdego żebraka przebywającego w mieście, regulowały rewiry i procedurę żebrania, nadzorowały zachowanie ubogich, stosowały różne sankcje za wszelakie nadużycia i ekscesy, jednocześnie precyzowały powinności ubogich braci i sióstr. Statut bractwa wileńskiego zabraniał siedzącymna ulicach żebrakom eksponowania swoich ułomności i chorób, pokazywania „skancerowanych i zgniłych” nóg, zakazywał kobietom wylegiwania się na żebraninie z dziećmi, przestrzegał przed pijaństwem i swawolami, czynieniem wrzasków, wszczynaniem kłótni po gospodach i ulicach, śpiewaniem frantowskich pieśni. Łamanie tych obwarowań zagrożone było karą oddania pół funta wosku ${ }^{118}$. Statut konfraterni krośnieńskiej groził wypędzeniem z miasta tym żebrakom, którzy przesiadywali w gospodach, pili gorzałkę, brali udział w zabawach i burdach ulicznych oraz zachowywali się nieprzyzwoicie. Kłótnie między członkami wspólnoty, zwłaszcza między żebrakami i mieszkańcami miejscowych szpitali, a także prowadzenie rozmów w kościele zagrożone było karami pieniężnymi i cielesnymi ${ }^{119}$. Zwierzchnicy stowarzyszenia, kontrolując żebraków, sprawdzali ,jak się sprawują, jakiej jałmużny używają, czy samopas nie chodzą"120. W podobnym tonie brzmiał statut konfraterni warszawskiej, który normował obyczaje pozostających pod kuratelą bractwa nędzarzy, nakazując im skromność i umiarkowanie, grożąc jednocześnie sankcjami za kłótnie, pijaństwa i bójki ${ }^{121}$.

Mówiąc o celach i zadaniach bractw ubogich, należy je rozpatrywać w kontekście dwu odrębnych grup członków stowarzyszenia. Jedni z nich - ubodzy, byli odbiorcami pomocy organizowanej ze strony bogatszej frakcji współbraci. Z kolei ci ostatni, wstępując do wspólnoty, zobowiązywali się świadczyć miłosierdzie i wsparcie konfratrom znajdującym się na przeciwstawnym biegunie materialnym. Za główny obowiązek bractwa ubogich poczytywały sobie opiekę nad chorymi ${ }^{122}$. Według statutu z 1595 r., członkowie bractwa ubogich w Krośnie w wypadku choroby lub trudności uzyskiwali pomoc od swoich konfratrów i zarządu. Korzystali wtedy z funduszu brackiego, a jeśli okazywał się on niewystarczający, mieli prawo, za zgodą miejscowego plebana, zbierać na ten cel jałmużnę w obrębie murów miejskich oraz w okolicznych wsiach i miasteczkach ${ }^{123}$. Podobnie było w konfraterni wileńskiej, w której na wypadek choroby lub śmierci któregoś z rejestrowych, biczownicy zobowiązani byli poinformować o tym starszych, by mogli sprowadzić choremu kapłana ze świętymi sakramentami, a gdyby umarł zorganizować mu pochówek. O chorobach i kalectwie swych współbraci orzekali czterej dziadowie, wyznaczeni przez starszego. Opieka i pomoc choremu

${ }^{117}$ Zaremska, Bractwa, s. 106.

${ }^{118}$ Kurczewski, Biskupstwo, s. 365.

${ }^{119}$ Budzyński, Dzieje opieki, s. 157.

${ }^{120}$ Tamże, s. 158.

${ }^{121}$ Karpiński, Pauperes, s. 324.

${ }^{122}$ Kopiczko, Ustrój i organizacja, s. 231.

${ }^{123}$ Budzyński, Dzieje opieki, s. 157-158. 
świadczona była przez braci i siostry z funduszu brackiego, a w wypadku jego braku z innych środków, które należało obmyśleć ${ }^{124}$.

Konfraternie ubogich ze składek swoich członków utrzymywały też szpitale -przytułki. Na Pomorzu i Śląsku bractwa delegowały jednego ze swoich członków do administracji szpitala, a pozostali bracia odwiedzali chorych szpitalników, którzy na ogół zdani byli wyłącznie na samoobsługę i własne siły. Oprócz zaspakajania potrzeb materialnych stowarzyszenia te troszczyły się o zaspokojenie potrzeb duchowych podopiecznych ${ }^{125}$. Bractwa związane na ogół poprzez świadczone usługi z lokalnymi szpitalami, z rzadka jednak prowadziły takie placówki na własną rękę. Zdarzało się to tylko konfraterniom dobrze prosperującym, np. bractwu ubogich w Gdańsku przy kościele św. Katarzyny, które ufundowało jeszcze przed zagarnięciem miasta przez Krzyżaków (przed 1308 r.) przytułek dla biednych pod wezwaniem św. Elżbiety ${ }^{126}$. Również bractwo ubogich w Krośnie powołało do życia przed 1580 r., przytułek dla żebraków pod wezwaniem św. Łazarza, dający utrzymanie 5 członkom wspólnoty ${ }^{127}$. Analogiczną inicjatywę wykazało warszawskie bractwo ubogich, fundując pod koniec XVII w. niewielki przytułek dla ubogich $^{128}$. Bliższego związku z miejscowymi szpitalami nie wykazywały krakowskie bractwa ubogich, nastawione przede wszystkim na własną wspólnotę. Pewnym wyjątkiem była konfraternia ubogich przy kościele św. Floriana na Kleparzu, której członkowie, w większości kobiety, wykonywali różne usługi pomocnicze w szpitalu św. Walentego dla trędowatych ${ }^{129}$.

Fundamentalną powinnością braci była troska o zapewnienie zmarłym, zwłaszcza ubogim i bezdomnym, chrześcijańskiego pochówku i pogrzebu, a także odprawianie za nich modlitw ${ }^{130}$. Udział w pogrzebach był nieodmiennie obowiązkiem braci i sióstr wszystkich bez wyjątku stowarzyszeń religijnych, dlatego niekiedy w literaturze nazywano je bractwami pogrzebowymi. Pochówkiem pielgrzymów, wędrowców oraz w ogóle obcych w mieście zajmowały się szczególnie bractwa ubogich na Pomorzu ${ }^{131}$. Niektórzy badacze uważają, że najistotniejsze w całej działalności tych bractw było organizowanie uroczystości i egzekwii pogrzebowych $^{132}$. W wypadku śmierci ubogiego, zwłaszcza szpitalnego, wszyscy członkowie bractwa w Jutrosinie zobowiązani byli do uczestnictwa w nabożeń-

${ }^{124}$ Kurczewski, Biskupstwo, s. 364-365.

${ }^{125}$ Kumor, Kościelne stowarzyszenia, s. 519.

${ }^{126}$ Z. Kropidłowski, Formy opieki nad ubogimi w Gdańsku od XVI do XVIII w., Gdańsk 1992, s. 77; tenże, Organizacja dziet mitosierdzia chrześcijańskiego w Gdańsku w XVI-XVIII w., w: Charitas. Miłosierdzie i opieka społeczna $w$ ideologii, normach postępowania i praktyce społeczności wyznaniowych w Rzeczypospolitej XV-XVIII wieku, red. U. Augustyniak, A. Karpiński, Warszawa 1999, s. 146.

${ }^{127}$ Budzyński, Dzieje opieki, s. 58, 158.

${ }^{128}$ Karpiński, Pauperes, s. 326-327.

${ }^{129}$ Zaremska, Bractwa, s. 96, 167.

${ }^{130}$ Wiśniowski, Bractwa religijne, s. 58; Kopiczko, Ustrój i organizacja, s. 231; Nowacki, Dzieje archidiecezji, s. 744.

${ }^{131}$ Zaremska, Bractwa, s. 140-141.

${ }^{132}$ Czarciński, Bractwa, s. 21. 
stwie żałobnym i godnym pogrzebie zmarłego, odmawiania za niego pacierzy a także kwartalnych wigilii i aniwersarzy za nieżyjących braci ${ }^{133}$. Do uczestnictwa w pogrzebie i niesienia ciała zmarłego zobowiązywał też wszystkich współbraci, pod rygorem kary zakupienia pół funta wosku na ołtarz, statut konfraterni wileńskiej ${ }^{134}$.

Bractwo pełniło pewne funkcje służebne wobec kościoła parafialnego. Przykładowo członkowie korporacji ubogich w Krośnie mieli obowiązek pilnowania i sprzątania świątyni ${ }^{135}$, natomiast podopieczni bractwa ubogich w Warszawie zobowiązani byli do wykonywania drobnych prac porządkowych w kościele św. Jana i jego najbliższej okolicy ${ }^{136}$. Od członków bractw ubogich, zawsze związanych z kościołami, wymagano w pierwszym rzędzie aktywnego i częstego uczestnictwa w praktykach religijnych. W bractwie warszawskim ich nieprzestrzeganie groziło karą siedzenia w kunie lub wpłaceniem przez winnego pewnej kwoty do specjalnej skrzynki ubogich ${ }^{137}$. W bractwie ubogich w Jarocinie konfratrzy, oprócz wspomnianych już uroczystości pogrzebowych i modlitw za zmarłych, mieli uczestniczyć w trzech mszach św. brackich tygodniowo, jednej o odpuszczenie grzechów, drugiej do Matki Boskiej, a trzeciej za zmarłych braci ${ }^{138}$. Z kolei konfratrzy wileńskiego bractwa ubogich mieli uczestniczyć na koszt bractwa w mszy „festowej” odprawianej 4 października na dzień św. Franciszka, co miesiąc - w dwu mszach czytanych, jednej za dobrodziejów żywych i umarłych, drugiej za dusze braci i sióstr, a oprócz tego w trzech żałobnych mszach śpiewanych oraz trzech rekwialnych czytanych ${ }^{139}$.

Bractwa ubogich, podobnie jak wszystkie inne korporacje religijne, związane były z kościołami parafialnymi, a tylko wyjątkowo z klasztornymi czy szpitalnymi. Niektóre z nich posiadały w tych świątyniach własne ołtarze i związane z nimi altarie lub nawet kaplice ${ }^{140}$. Altarii nie miało zaledwie co trzecie $\mathrm{z}$ bardzo licznych korporacji ubogich diecezji poznańskiej ${ }^{141}$. Nieco rzadziej bractwa ubogich dysponowały swoimi brackimi kaplicami. Posiadała ją np. konrafaternia w Tczewie ${ }^{142}$, czy w Grudziądzu, gdzie w kościele parafialnym pod wezwaniem św. Mikołaja istniała kaplica bracka św. Michała ${ }^{143}$. Jako stowarzyszenia religijne, organizowane w kościołach parafialnych, posiadały zawsze swego duchownego promotora (kapelana), którym był z reguły kapłan pracujący w parafii, często pleban ${ }^{144}$.

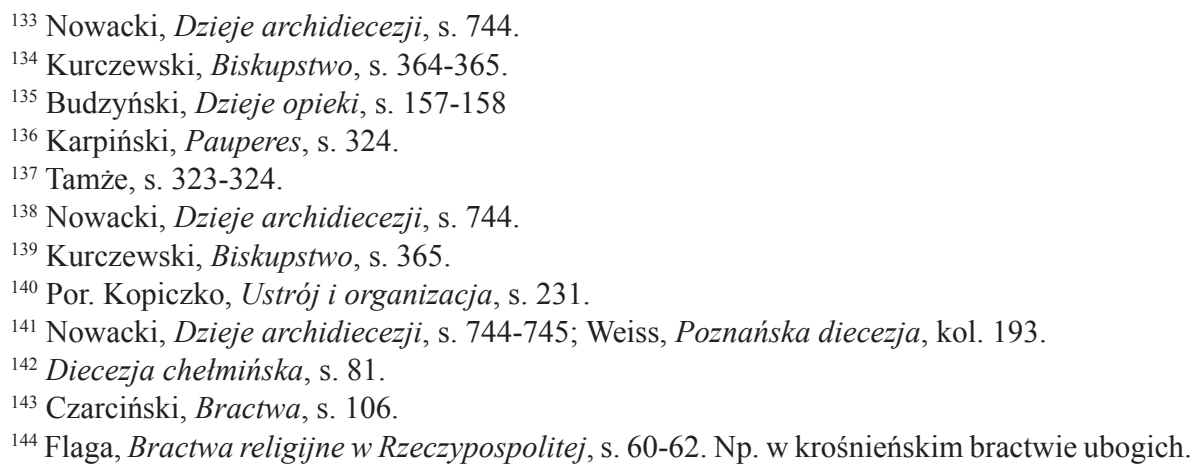


Oprócz promotora, konfraternie miały mniej lub bardziej rozbudowany zarząd złożony z ludzi świeckich. W poszczególnych konfrateniach ubogich nie był on jednolity i różnił się często liczbą i kategorią oficjalistów i funkcyjnych. Na czele zarządu stali z reguły, pochodzący z corocznego wyboru, starsi nazywani też seniorami (seniores, rzadziej provisores, procuratores sive directores), odpowiedzialni za sprawy finansowe. Bardzo często, jak to miało miejsce w Bractwie Ubóstwa Chrystusowego na krakowskim Kleparzu, było ich czterech ${ }^{145}$. Niekiedy jednak bractwo zarządzane było przez jednego naczelnego seniora, któremu podlegali jego asystenci lub seniorzy pomocniczy. Wybrany w 1595 r. zarząd bractwa ubogich w Krośnie tworzyli, co ciekawe, wyłącznie osoby pochodzące z innych miast. Starszym został Jan Mierosławski z Biecza, zaś dwoma asystentami Szczepan z Kobylan i Bartosz z Bnina ${ }^{146}$. Brak nazwisk przy tych ostatnich sugeruje ich plebejskie lub nawet żebracze pochodzenie. O tym, że do zarządu wybierano niekiedy żebraków świadczy tekst dyplomu z $1433 \mathrm{r}$. bractwa ubogich przy krakowskim kościele Wszystkich Świętych, w którym wśród inicjatorów i pierwszych członków bractwa, oprócz dwu witryków związanych z parafią, figurują dwaj biedacy „Albertus et Miroslaus pauperes homines et mendici”. W pół wieku później znikli z grona seniorów, a starszyznę korporacyjną stanowili już wyłącznie rzemieślnicy ${ }^{147}$. W składzie władz warszawskiego bractwa ubogich pojawiają się funkcje prowizorów, starszych i przełożonych, a także kościelnych, sprawujących bezpośredni nadzór nad „brackimi” żebrakami i orzekających o prawie ubogich do zbierania jałmużny oraz trzymających skrzynkę ubogich. Ubodzy należący do bractwa posiadali swoisty samorząd, który stanowili dwaj starsi żebracy, wybrani przez ogół i akceptowani przez kościelnych. W drugiej połowie XVI w. naczelna władza stowarzyszenia była jednak jednoosobowa, na jej czele stał senior bądź prefekt, obaj obywatele Warszawy ${ }^{148}$. Według statutu założycielskiego z 1636 r., konfraterni wileńskiej przewodniczył jeden z mieszczan wileńskich posesjonat, posiadający domy w mieście i prawo magdeburskie, nazywany starszym. Wspomagało go czterech członków, również noszących miano starszych, wybieranych spośród dziadów kościelnych, którzy trzymali rejestr wszystkich ubogich ulicznych. Dodatkowo z grona ogółu dziadów wyznaczano czterech lub więcej dozorców - biczowników, którzy sprawowali dozór nad ogółem żebraków. Bractwo wileńskie posiadało też urząd pisarza, sprawowany przez jednego z ubogich posiadających umiejętność pisania ${ }^{149}$. Analizując zachowane statuty, można powiedzieć, że bractwa ubogich w zasadzie dla biedaków i nędzarzy miejskich, zarządzane były jednak przez osoby sprawujące władze $w$ mieście ${ }^{150}$. Jedynie w co niektórych, np. wileńskim, ubodzy (dziadowie) piastowali niższe funkcje w zarządzie, i to bardziej o charakterze porządkowo-nadzorującym, czy aparatu przymusu (biczownicy, nadzorcy).

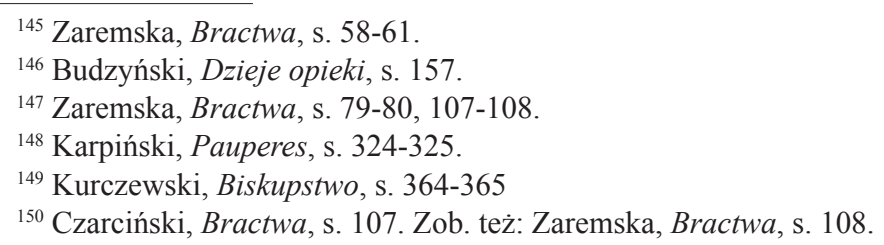


Wyrazem żywotności i demokratyzmu bractw były okresowe spotkania, gromadzące wszystkich członków, tzw. schadzki dziadowskie. W korporacji wileńskiej, organizowano je co miesiąc $\mathrm{w}$ gospodzie, czyli w domu prezydującego starszego, w którym mieściła się skrzynka bracka na zebrane pieniądze i składki, a także rejestry ubogich i księgi do wpisywania uchwał. Na schadzkach, prowadzonych przez gospodarza - pierwszego starszego bractwa, w obecności pozostałych „rocznych starszych”, przyjmowano nowych członków, podejmowano najważniejsze decyzje i uchwały dotyczące życia wspólnoty. Wtedy też członkowie uiszczali do skarbony po jednym groszu obowiązkowej składki ${ }^{151}$. W konfraterni krośnieńskiej składki członkowskie do skrzynki brackiej pobierano cztery razy w roku, w wysokości pół grosza od osoby w XVII w., natomiast już w znacznie wyższej kwocie w następnym stuleciu ${ }^{152}$. Również kwartalny cykl płacenia składek obowiązywał w warszawskim bractwie ubogich, tyle że składka była tam bardzo zróżnicowana i zależała od hojności i zamożności poszczególnych osób. Była poza tym wyższa, gdyż w połowie XVII w. przeważały wpłaty od 10 do 30 gr. na kwartał. Należy jednak pamiętać, że kontubernia warszawska posiadała ekskluzywny charakter, w przeciwieństwie do typowo żebraczej - krośnieńskiej. Zebrane fundusze przeznaczone były m.in. na wydatki związane $\mathrm{z}$ leczeniem chorych oraz pogrzebami nędzarzy ${ }^{153}$.

Wszystkie dochody, wcześniej zarejestrowane w księgach, deponowane były w skrzynce brackiej, do której jeden klucz w bractwie wileńskim trzymał starszy kościelny, zaś drugi starszy uliczny ${ }^{154}$. W bractwie warszawskim skrzynką opiekowali się kościelni ${ }^{155}$. Składki kwartalne i jałmużny uzbierane przez żebraków uzupełniane były niewysokimi legatami pieniężnymi od różnych dobrodziejów, również nie będących członkami bractwa. $Z$ reguły oddawano je mieszczanom $\mathrm{w}$ formie pożyczek wyderkafowych ${ }^{156}$. W przeciwieństwie do innych bractw, konfraternie ubogich nie posiadały na ogół nieruchomości w postaci ziemi, czy budynków ${ }^{157}$.

Bractwa ubogich, nastawione na pomoc żebrakom i przyjmujące ich w poczet swych członków, z natury rzeczy stawały się konfraterniami żebraczymi. Swiadczy o tym podwójne określenie, fraternitas pauperum seu mendicorum, używane w stosunku do konfraterni przy krakowskim kościele Wszystkich Świętych ${ }^{158}$. Jednakże jeden z badaczy, owo bractwo (fraternitas mendicantium vel pauperum) zaliczył do oddzielnej grupy konfraterni żebraków, pomijając go w podawanym wcześniej wykazie bractw ubogich ${ }^{159}$. Niewątpliwie było ono także bractwem że-

\footnotetext{
${ }^{151}$ Kurczewski, Biskupstwo, s. 364-365

${ }^{152}$ Budzyński, Dzieje opieki, s. 158.

${ }^{153}$ Karpiński, Pauperes, s. 324-325.

${ }^{154}$ Kurczewski, Biskupstwo, s. 365

${ }^{155}$ Karpiński, Pauperes, s. 324.

${ }^{156}$ Tamże, s. 326; Budzyński, Dzieje opieki, s. 158.

${ }^{157}$ Karpiński, Pauperes, s. 326.

${ }^{158}$ Zaremska, Bractwa, s. 79-80, 107175.

${ }^{159}$ Kumor, Kościelne stowarzyszenia, s. 522-523; tenże, Kościelne stowarzyszenia, s. 327. Autor ten wspomina też o bractwie żebrzących (mendicantium) przy kościele św. Michała w Nowym
} 
braczym, bo zrzeszało również ludzi skrajnie ubogich, często bezdomnych i żebrzących po ulicach. Różnice między tzw. ubogimi a żebrakami były na tyle subtelne i trudne do uchwycenia, że organizowane z myślą o nich korporacje przyjmowały jednych i drugich traktując ich jako tę samą kategorię potrzebujących, co przejawiało się niekiedy w używaniu nazw o charakterze synonimów.

Inny status i charakter posiadało Bractwo Żebraków (Fraternitas Mendicorum) założone w 1592 r. w Krakowie. W przeciwieństwie do związanych z kościołami konfraterni ubogich, była to organizacja świecka, powołana przez radę miejską i jej podległa. Miała na celu administracyjne rozwiązanie problemu wzrastającej liczby żebraków i włóczęgów w mieście i zapobieżenie czynionym przez nich skandalom i nieporządkom. Do konfraterni przyjmowano wyłącznie żebraków krakowskich - cierpiących i chorych, natomiast nie dopuszczano obcych i skłonnych do pijaństwa i zabaw. Żebraków kreujących problemy i ekscesy władze organizacji wydalały z miasta, podobnie czyniły z obcymi mieszkańcami szpitali, którzy mogli w nich prosić o wsparcie nie dłużej niż trzy dni ${ }^{160}$.

\section{BRACTWA MILOSIERDZIA PIOTRA SKARGI}

Zarówno bractwa szpitalne, jak i bractwa ubogich czasy swojej prosperity przeżywały w średniowieczu, które poprzez swoją afirmację ubóstwa stwarzało sprzyjający grunt do ich rozwoju. W następnej epoce stały się już zjawiskiem zanikającym, a tuż przed rozbiorami wręcz wyjątkowym. Tymczasem, po kryzysie związanym z rozprzestrzenianiem się reformacji, w atmosferze reform Soboru Trydenckiego, nastąpił żywiołowy rozwój bractw religijnych, będących ważnym czynnikiem odnowy religijnej w Kościele katolickim ${ }^{161}$. Wśród licznych, nowych konfraterni, w większości dewocyjnych, pojawiło się też kilka bractw charytatywnych, choć nie zyskały takiej popularności w społeczeństwie, jak średniowieczne konfraternie ubogich, co wolno łączyć z dość istotną zmianą postaw wobec żebraków ${ }^{162}$. Zdecydowanie najważniejszą z nich było bractwo miłosierdzia, zakładane w końcu XVI w. przez kaznodzieję i spowiednika królewskiego, jezuitę Piotra Skargę, na wzór podobnych bractw miłosierdzia szerzących się już na przełomie XI i XII w. w Hiszpanii i we Włoszech, a w XIII w. także w Normandii. Nawiązywało także do nich, świadczące uczynki miłosierne względem chorych i ubogich, bractwo założone w 1617 r. przez św. Wincentego Paulo w Châtillon oraz późniejsze Konferencje św. Wincentego. Pierwsze wzorcowe bractwo miłosierdzia zorganizował P. Skarga, na wzór rzymskiej wspólnoty brackiej, w 1584 r. przy jezuickim kościele św. Barbary w Krakowie ${ }^{163}$. W 1588 r. zatwierdził go i podniósł do rangi arcybractwa papież Sykstus V. Następnie papież Grzegorz XIV

\footnotetext{
Sączu, założonym przed 1608 r. Zob. tenże, Archidiakonat sądecki, s. 112.

${ }^{160}$ Zaremska, Bractwa, s. 109-111.

${ }^{161}$ Kuźmak, Bractwo kościelne, kol. 1014-1015; S. Litak, Parafie, s. 228; Litak, Bractwa, s. 510; K. Górski, Zarys dziejów duchowości w Polsce, Kraków 1986, s. 203-206.

${ }^{162}$ Budzyński, Dzieje opieki, s. 159.

${ }^{163}$ Kuźmak, Natoński, Bractwo Miłosierdzia, kol. 1021; Litak, Parafie, s. 231; tenże, Bractwa, s. 513; Kumor, Kościelne stowarzyszenia, s. 520; tenże, Kościelne stowarzyszenia, s. 323; Flaga, Bractwa religijne w Rzeczypospolitej, s. 47.
} 
w 1591 r. rozszerzył jego przywileje, król Zygmunt III Waza uniezależnił go od władz miejskich i zezwolił zakładać w całej Rzeczypospolitej. Dalsze przywileje królewskie bractwo w Krakowie otrzymało od Jana Kazimierza (1649) i Jana III Sobieskiego $(1673)^{164}$.

Propagowane przez samego Skargę i zakon jezuitów bractwo miłosierdzia, na wzór krakowskiego, rozprzestrzeniło się w najważniejszych miastach Rzeczypospolitej, m.in. w Wilnie (1583), Warszawie (1589), Poznaniu (1599), Puttusku (przed 1600), Łowiczu (1600), Lwowie (1601), Zamościu (1601), Rzeszowie (1636) ${ }^{165}$, Lublinie (1589 lub 1596) ${ }^{166}$, Przemyślu ${ }^{167}$. Przypomnieć wypada, że lwowskie bractwo miłosierdzia stanowiło kontynuację średniowiecznej przykatedralnej konfraterni ubogich, po jej odnowieniu w 1597 r. i przyjęciu nowej struktury i koncepcji działania propagowanej przez P. Skargę ${ }^{168}$.

Choć bractwa miłosierdzia zakładano w większych miastach, to jednak nie pozbawione ich były również mniejsze ośrodki i parafie. Przykładem jest archidiakonat lubelski, gdzie oprócz konfraterni w Lublinie przy klasztorze jezuitów, podobne stowarzyszenia charytatywne funkcjonowały przy kościołach parafialnych w Ostrowie (1598), Wąwolnicy (1601-1603), a nawet w podlubelskiej parafii wiejskiej Abramowice (1591-1600) ${ }^{169}$. Aż pięć bractw, pod rozszerzona nazwą, Bractw Miłosierdzia Bożego odnotowano na terenie prepozytury wiślickiej, w tym aż cztery na wsiach, w: Bolesławiu (przed 1606), Szczaworyżu (1664), Chotelu Czerwonym (przed 1679 r.), Stróżyskach (1711) i tylko jedno w mieście Nowym Korczynie (przed 1740 r.) ${ }^{170}$. Bractwo miłosierdzia, rozwijające działalność charytatywną, dość często występowało w XVII i XVIII w. na terenie diecezji poznańskiej ${ }^{171}$. Oprócz jezuitów ${ }^{172}$, szerzycielami bractwa i często związanego z nim banku pobożnego stały się też synody diecezjalne: krakowskie z lat 1601 i 1621 oraz przemyski z 1635 r. Synod krakowski z 1601 r. stwierdzając, że „bractwo istnieje już w wielu miastach Królestwa i po licznych miejscach diecezji”, zalecał proboszczom, by je zakładali przy kościołach parafialnych. Z hierarchów kościelnych lansowali je również prymasi Bernard Maciejowski i Stanisław Karnkowski,

${ }^{164}$ Kuźmak, Natoński, Bractwo Miłosierdzia, kol. 1021; Flaga, Bractwa religijne w Rzeczypospolitej, s. 47-48.

${ }^{165}$ Kuźmak, Natoński, Bractwo Miłosierdzia, kol. 1021-1022; Kumor, Kościelne stowarzyszenia, s. 522; tenże, Kościelne stowarzyszenia, s. 326; Łukaszewicz, Krótki opis, s. 150. Według A. Karpińskiego (Pauperes, s. 315) bractwo warszawskie powstało w $1590 \mathrm{r}$.

${ }^{166}$ Flaga, Bractwa religijne w archidiakonacie lubelskim do poczatku XVII wieku, s. 153.

${ }^{167}$ Budzyński, Dzieje opieki, s. 159.

${ }^{168}$ Krętosz, Organizacja, s. 275, 281-283. Według innych autorów lwowskie bractwo miłosierdzia miało powstać w 1601 r. Zob. Budzyński, Dzieje opieki, s. 159

${ }^{169}$ Flaga, Bractwa religijne w archidiakonacie lubelskim do poczatku XVII wieku, s. 153-154, 159, 165; tenże, Bractwa religijne w archidiakonacie lubelskim do końca XVIII wieku, s. 302, 314, $320,324,329$.

${ }^{170}$ E. Wiśniowski, Prepozytura wiślicka do schytku XVIII wieku, Lublin 1976, s. 31, 46, 73, 172, 179, 188, 207.

${ }^{171}$ Nowacki, Dzieje archidiecezji, s. 748.

${ }^{172}$ Bractwo w Poznaniu założył jezuita Radzimiński: Nowacki, Dzieje archidiecezji, s. 748; Chodyński, Bractwo, s. 575-576. 
który osobiście erygował bractwo z bankiem pobożnym i szpitalem w Łowiczu ${ }^{173}$. Generalnie, choć bractwo miłosierdzia kierowane było w większości przez jezuitów, to jednak podlegało jurysdykcji biskupów ordynariuszy, co wyraźnie przypominał synod biskupa krakowskiego Marcina Szyszkowskiego z 1621 r. ${ }^{174}$

Okres rozwoju bractw miłosierdzia przypadł na koniec XVI i początek XVII w., a więc na czas życia swego założyciela i orędownika. Choć przetrwały jego śmierć, to jednak nowe fundacje w zasadzie już nie powstawały, a dotychczas istniejące, stopniowo zanikały i ulegały zapomnieniu. Jako wyjątek należy traktować ufundowanie w 1742 r. drugiego bractwa miłosierdzia w Warszawie pod wezwaniem Św. Trójcy przy parafii i kościele Św. Trójcy ${ }^{175}$. Niektóre bractwa, jak np. w Wąwolnicy i Abramowicach upadły już na początku XVII w., jednak dwa inne z tego terenu, w Ostrowie i Lublinie, nadal działały w XVII i XVIII stuleciu. Prawdopodobnie przetrwały tak długo dzięki przeniesieniu ich i złączeniu z kościołami szpitalnymi, gdzie być może pomagały tamtejszym przytułkom i ich pensjonariuszom. Bractwo lubelskie zmieniło przynależność z kościoła jezuickiego na szpitalny kościół św. Wojciecha w 1736 r., natomiast ostrowskie z kościoła parafialnego na kościół szpitalny Św. Krzyża i Przemienienia Pańskiego w XVII w. ${ }^{176}$ Co ciekawe, tylko jedno $\mathrm{z}$ wymienionych bractw miłosierdzia w prepozyturze wiślickiej upadło w XVII w. (w Szczaworyżu, przed 1664 r.), pozostałe cztery działały jeszcze w 1711 lub nawet w 1740 r. (w Nowym Korczynie) ${ }^{177}$. W latach 1747-1749 w diecezji krakowskiej funkcjonowały zaledwie cztery bractwa miłosierdzia $^{178}$, co stanowiło zjawisko marginalne w skali wielkiej diecezji. Tylko dwie konfraternie miłosierdzia prowadzone przez jezuitów przetrwały do $1772 \mathrm{r}$. w Wielkopolsce ${ }^{179}$. Efemerydami okazały się dwa bractwa w ziemi sanockiej i przemyskiej, w Przemyślu i Rzeszowie, przy czym nieco dłużej funkcjonowała konfraternia przemyska, która w połowie XVII w. posiadała nawet w katedrze własną altarię ${ }^{180}$. To wszystko potwierdza niemal całkowity zanik idei i dzieła jezuickiego kontrreformatora. Fragmentaryczny stan badań uniemożliwia pełniejsze zrekonstruowanie zasięgu terytorialnego i skali ilościowej bractw miłosierdzia, pozwala jednak ukazać ogólne tendencje, a w zasadzie stagnację i regres, jaki nastąpił w ich rozwoju po śmierci Skargi. Pomimo głębokiego kryzysu organizacje te nie zanikły całkowicie i bezpowrotnie, dając w przyszłości grunt pod ich odrodzenie, w zmodyfikowanej i dostosowanej do nowych potrzeb postaci.

Bractwo miłosierdzia miało charakter otwarty. Mogli do niego należeć wy-

${ }^{173}$ Kumor, Kościelne stowarzyszenia, s. 522; tenże, Kościelne stowarzyszenia, s. 325-326; tenże, Bank Pobożny, mons pietatis, EK, t. 1, Lublin 1985, kol. 1306.

${ }^{174}$ Kuźmak, Natoński, Bractwo Miłosierdzia, kol. 1021.

${ }^{175}$ Szwed, Bractwa religijne, s. 39-40, aneks.

${ }^{176}$ Flaga, Bractwa religijne $w$ archidiakonacie lubelskim do końca XVIII wieku, s. 312-313, 320-321, 343; tenże, Bractwa religijne w archidiakonacie lubelskim do poczatku XVII wieku, s. 167. Zob. też. Wadowski, Kościoły, s. 155.

${ }^{177}$ Wiśniowski, Prepozytura, s. 31, 46, 73, 172, 179, 188, 207.

${ }^{178}$ Flaga, Rodzaje, s. 587; tenże, Bractwa religijne w archidiakonacie lubelskim do końca XVIII wieku, s. 329.

${ }^{179}$ Nowacki, Dzieje archidiecezji, s. 747.

${ }^{180}$ Budzyński, Dzieje opieki, s. 159, 166. 
łącznie katolicy obojga płci, wywodzący się z różnych środowisk społeczno-zawodowych, jakkolwiek udział w zebraniach i wyborach zarządu brali jedynie mężczyźni ${ }^{181}$. Największym było prototypowe bractwo miłosierdzia w Krakowie. Już w 1588 r. wpisało się do niego 256 mężczyzn i 239 sióstr ${ }^{182}$, w latach 15881600 w rejestrze pojawiło się 745 osób, zaś w latach 1584-1684 stowarzyszenie pozyskało 2061 członków ze wszystkich warstw społecznych. Wśród nich było 221 biskupów, prałatów i innych duchownych. W dalszym stuleciu (1684-1784) liczba konfratrów zmalała do 348 osób: 170 niewiast, 150 mężczyzn i 28 duchownych, co stanowi dowód postępującego kryzysu tego typu konfraterni ${ }^{183}$. Do krakowskiego bractwa miłosierdzia należeli m.in. król Zygmunt III Waza i jego dworzanie, a w różnych okresach jego działalności magnaci szlachta i bogate mieszczaństwo ${ }^{184}$. Mniejszym od krakowskiego pod względem liczebności członków było warszawskie bractwo miłosierdzia. Spis założycielski z 1590 r. wymienia 74 osób; prawdopodobnie do końca tego roku przybyło ich jeszcze 118. W 1659 r. na mocno zaniżonej liście konfratrów znajdowało się 83 osób ${ }^{185}$. W końcu XVI i pierwszej połowie XVII w., przynajmniej wśród urzędników brackich, przeważali bogatsi rzemieślnicy i kupcy oraz przedstawiciele zamożniejszej szlachty i duchowieństwa. Honorowymi członkami bractwa warszawskiego byli Zygmunt III Waza, jego żona Anna i Władysław IV ${ }^{186}$. Wśród członków bractw miłosierdzia propagowanych przez P. Skargę trudno spotkać przedstawicieli świata żebraków i ubogich, którzy byli po prostu adresatami pomocy i opieki ze strony zrzeszonych w tej organizacji osób zamożnych i wyżej postawionych społecznie. To m.in. różniło je od konfraterni ubogich, które choć dużo mniej liczne niż w średniowieczu, nadal tu i ówdzie działały razem z bractwami miłosierdzia.

Według wytycznych P. Skargi celem bractwa miłosierdzia było nie tylko wspomaganie ubogich, ale i wychowywanie społeczeństwa w poczuciu obowiązku chrześcijańskiego miłosierdzia ${ }^{187}$. Celem krakowskiego bractwa ks. Skargi miało być niesienie pomocy materialnej tym ,[...] którzy pod własnym dachem cierpią nędzę i ucisk, utrapieni są przez różne choroby, a wstydząc się żebrać, nie mają znikąd pomocy". Członkowie bractwa zobowiązani byli do: dawania tygodniowych, dobrowolnych bądź w zadeklarowanej kwocie jałmużn, odwiedzania co tydzień więzienia oraz szpitali w Krakowie i obdarzania przebywających tam osób ,jałmużną świecką i duchową", zbierania datków przy kościele św. Barbary lub w innych wyznaczonych miejscach, uczestnictwa w schadzkach oraz pogrzebach współbraci i sióstr, a także rozmyślania w niedzielę po kazaniu o miłosierdziu i rodzajach ubóstwa. Dystrybucją jałmużny między potrzebujących zajmowali się dwaj tygodniowi wizytatorzy, mający również nawiedzać ubogich i cho-

${ }^{181}$ Karpiński, Pauperes, s. 315; Flaga, Bractwa religijne w Rzeczypospolitej, s. 47.

${ }^{182}$ Flaga, Bractwa i sodalicje, s. 146.

${ }^{183}$ Kumor, Kościelne stowarzyszenia, s. 324 -325, 521.

${ }^{184}$ Kuźmak, Bractwo kościelne, kol. 1021.

${ }^{185}$ Karpiński, Pauperes, s. 316-317; F. Giedroyć, Rys historyczny szpitala św. Łazarza w Warszawie, Warszawa 1997, s. 5-6, 22-23.

${ }^{186}$ Karpiński, Pauperes, s. 317.

${ }^{187}$ Kuźmak, Natoński, Bractwo Miłosierdzia, kol. 1021. 
rych $^{188}$. W podobnym duchu zadania konfratrów formułowały statuty warszawskiego bractwa miłosierdzia, powstałego również z inicjatywy P. Skargi. Według nich „opatrywać chcą bracia tego Bractwa ze spólnej jałmużny, ludzie domowem ubóstwem, a zwłaszcza niemocą i inną nędzą strapione, którzy się żebrać wstydzą, ani mogą i pomocy znikąd nie mają". Treść tego zapisu wskazuje, że pomoc ze strony bractwa nie przysługiwała biednym niezamieszkującym w swoich domach, zalegającym place i ulice miejskie. Obejmując wsparciem wyłącznie prawdziwie potrzebujących, bracia mieli czuwać: ,aby się jałmużna ludzka [...], dobrze obracała a ludziom lekkim, pijanicom, kosternikom, próżnującym etc. miasto pociechy, przyczyną nie była”. Obok udziału w odbywających się raz w miesiącu schadzkach, bracia zobowiązani byli do stałych cotygodniowych składek do „skrzynki ubogich” oraz dodatkowych dobrowolnych datków. Analogicznie jak w Krakowie, powinnością dwóch braci było nawiedzanie osób przebywających w szpitalu oraz więzieniu i rozdzielanie między nich jałmużny brackiej. Zalecano, by na takie spotkania przyprowadzali kapłana, który mógłby pocieszać ubogich, chorych i więźniów ${ }^{189}$. Władze bractwa dbały, by mieszkańcy szpitali nie czekali biernie na pomoc i datki z zewnątrz, a sami angażowali się w ich zbieranie. Dlatego np. ubodzy z lubelskiego szpitala św. Łazarza w Lublinie prowadzonego przez bractwo miłosierdzia chodzili po mieście z trzema skarbonami, z których prowizorzy rozdzielali dochód między nich co sobotę ${ }^{190}$.

Wymienione powinności dobroczynne członków bractw miały charakter uniwersalny i były wspólne dla wszystkich innych bractw miłosierdzia. Gama działań ze strony tych organizacji była jednak o wiele szersza i zależała od pojawiających się trudnych i niespodziewanych okoliczności i zdarzeń. W sytuacjach różnego typu klęsk, kryzysów czy epidemii bractwa spontanicznie i na bieżąco reagowały, niosąc pomoc potrzebującym. Na przykład w czasie zarazy dżumy z lat 1624-1625 korporacja warszawska rozdzieliła pomiędzy zubożałych i chorych kwotę 8 000-9 000 florenów ${ }^{191}$. W 1590 r. bractwo wspomagało ofiarą pieniężną pogorzelców, zaś od 1648 r. otaczało stałą opieką jedną z mieszczanek, udzielając jej aż do końca życia zapomogi. Część dochodów obracało też na uposażenie niezamożnych kobiet chcących wyjść za mąż, co było zresztą zgodne z ideą P. Skargi udzielania pomocy ubogim dziewczętom na wypadem małżeństwa. Zwyczajowy i symboliczny wydźwięk posiadała uchwała warszawskiego bractwa miłosierdzia z 1616 r. o ufundowaniu obiadu dla ubogich w każdy Wielki Czwartek, albo Wielką Środę po ceremonii obmycia nóg ${ }^{192}$.

Zgodnie z duchem nowych czasów bractwa starały się nie tylko pomagać żebrakom i chorym, co przede wszystkim przeciwdziałać pauperyzacji niektórych

${ }^{188}$ Chodyński, Bractwo, s. 574; Kumor, Kościelne stowarzyszenia, s. 520-521; tenże, Kościelne stowarzyszenia, s. 323-324.

${ }^{189}$ Karpiński, Pauperes, s. 315; Giedroyć, Rys historyczny szpitala, s. 9, 26-27.

${ }^{190}$ Z. Góralski, Szpitale na Lubelszczyźnie w okresie przedrozbiorowym w okresie przedrozbiorowym, Warszawa-Łódź 1982, s. 104; Wadowski, Kościoły, s. 155, 402.

${ }^{191}$ Karpiński, Pauperes, s. 321; tenże, Opieka nad chorymi i ubogimi w miastach polskich $w$ czasie epidemii w XVII-XVIII wieku, w: Charitas. Miłosierdzie i opieka społeczna $w$ ideologii, normach postępowania i praktyce społeczności wyznaniowych w Rzeczypospolitej XV-XVIII wieku, red. U. Augustyniak, A. Karpiński, Warszawa 1999, s. 226.

${ }^{192}$ Karpiński, Pauperes, s. 321-322. 
grup społecznych przez tworzenie specjalnych fundacji zapomogowych: banków pobożnych, fundacji stypendialnych i posagowych ${ }^{193}$. Dlatego też z bractwem krakowskim nieprzypadkowo związana była od samego niemal początku jeszcze jedna instytucja charytatywna o profilu kredytowym, założony w $1587 \mathrm{r}$. przez Skargę bank pobożny (mons pietatis), mający udzielać bezprocentowych pożyczek pod zastaw osobom zubożałym, będącym czasowo w trudnej sytuacji życiowej ${ }^{194}$. Inicjatywa zakładania tych instytucji była reakcją na rozpowszechniająca się lichwę, zwłaszcza żydowską, potępioną oficjalnie przez Kościół ${ }^{195}$.

Twórca polskich banków pobożnych P. Skarga wzorował się na podobnych instytucjach dobroczynnych zakładanych od połowy XV w. we Włoszech, dokładnie w Państwie Kościelnym. Popierane przez wielu papieży tego czasu, zwłaszcza Leona X, który bullą Inter multiplices z 1515 r., wziął je w obronę przed atakami ze strony Żydów i niektórych zakonów, zapewniając im opiekę ze strony Kościoła i polecając zakładanie w całym świecie chrześcijańskim ${ }^{196}$. Skarga korzystał też z wzorców kardynała Karola Boromeusza, biskupa mediolańskiego, propagatora reformy trydenckiej, który polecał zakładanie banków pobożnych w swej diecezji197. Sam pomysł założenia podobnej instytucji w Polsce nie był pierwszy. Jeszcze prymas Jan Łaski przedstawił Zygmuntowi Staremu i stanom sejmowym projekt utworzenia bractw mons pietatis, który nieco później ponowił daremnie Andrzej Frycz Modrzewski ${ }^{198}$.

W Polsce banki pobożne rzadziej nazywano też górami pobożności ${ }^{199}$, lub skarbcami ubogich i skarbcami miłosiernych (Wilno) ${ }^{200}$. Jako instytucje charytatywne o charakterze kościelnym, często związane z bractwami miłosierdzia, same w sobie stanowiły rodzaj bractw miłosierdzia, a raczej były ich dopełnieniem. Tak czy inaczej, na wzór banku krakowskiego szybko rozprzestrzeniły się po w całym $\mathrm{kraju}^{201}$.

Dokładnie cele banku statut precyzował w następujący sposób: ,aby ludziom potrzebnym do pewnego czasu darmo bez lichwy wszelakiej, na fanty pewne, rzeczy ruchome, pieniądze pożyczać" ${ }^{202}$. Banki pobożne działały przy bractwach miłosierdzia w największych miastach polskich, w: Krakowie, Warszawie, Pozna-

${ }^{193}$ Budzyński, Dzieje opieki, s. 152, 159.

${ }^{194}$ Litak, Parafie, s. 23; tenże, Bractwa, s. 513; Kumor, Kościelne stowarzyszenia, s. 521; tenże, Kościelne stowarzyszenia, s. 324.

${ }^{195}$ Karpiński, Pauperes, s. 324.

${ }^{196}$ Kumor, Bank Pobożny, kol. 1305.

${ }^{197}$ Flaga, Bractwa religijne w Rzeczypospolitej, s. 214.

${ }^{198}$ Kumor, Bank Pobożny, kol. 1305; tenże, Kościelne stowarzyszenia, s. 521; tenże, Kościelne stowarzyszenia, s. 324.

${ }^{199}$ Flaga, Bractwa religijne w Rzeczypospolitej, s. 214.

${ }^{200}$ Kurczewski, Biskupstwo, s. 353, 367.

${ }^{201}$ Flaga, Bractwa religijne w Rzeczypospolitej, s. 214; tenże, Działalność charytatywna, s. 386 .

${ }^{202}$ I. Polkowski, Bractwo miłosierdzia, w: Księga pamiatkowa Arcybractwa Miłosierdzia i Banku Pobożnego w Krakowie (1584-1884), Kraków 1884, s. 55. 
niu, Łowiczu, Wilnie ${ }^{203}$. Pewnym wyjątkiem był bank w Zamościu, założony w 1601 r. przez Jana Zamoyskiego, który był instytucją niezależną od miejscowego bractwa miłosierdzia ${ }^{204}$. Bank warszawski, krakowski i łowicki założono jednocześnie z bractwami miłosierdzia, co jeszcze bardziej podkreśla ścisły dualizm obu tych instytucji.

Choć obie instytucje występowały w integralnym ze sobą związku, to jednak nie przy każdym bractwie działał bank pobożny. Nie było ich na ogół w mniejszych miastach i parafiach, w których istniały konfraternie miłosierdzia. Jednakowoż tam, gdzie występowały razem prawie zawsze zakładały i prowadziły szpitale, przytułki, domy wychowawcze dla sierot i inne placówki charytatywne, opiekując się ich pensjonariuszami ${ }^{205}$. Przykładem jest warszawskie bractwo miłosierdzia, które kierowało i opiekowało się założonym przez siebie w $1591 \mathrm{r}$. szpitalem św. Łazarza nastawianym na przyjmowanie ubogich i chorych wyrzuconych na ulicę, zwłaszcza dotkniętych chorobami wenerycznymi. Wspierało też instytucje materialnie. Pod osobistą opieką członków bractwa znajdowało się stale 12 ubogich pensjonariuszy tego szpitala ${ }^{206}$. Lubelski szpital św. Łazarza będący w posiadaniu bractwa miłosierdzia, a od 1733 r. znajdujący się pod zarządem sióstr miłosierdzia, był najlepiej urządzony na całej Lubelszczyźnie ${ }^{207}$. Służebne zadania i kontrolne uprawnienia wobec szpitali i ich pensjonariuszy posiadało wileńskie bractwo miłosierdzia. Jeszcze w 1799 r. biskup Jan Nepomucen Kossakowski w liście pasterskim zobowiązywał dozorców brackich do pilnowania, ażeby wszystkie dochody z funduszu, z ofiar pobożnych i jałmużny zebrane, wyłącznie na potrzeby szpitala były obrócone. Jednocześnie apelował do nich, by w szpitalu umieszczali miejscowych chorych i niedołężnych, a symulujących, obcych, młodych i zdrowych odsyłali do rodzin oraz „,panom na służbę i robotę"

Niezależnie od istniejącego banku pobożnego, bractwo miłosierdzia w Poznaniu, dysponując wysokimi funduszami i kapitałami, samo pożyczało pod zastaw pieniądze bez procentów uboższym potrzebującym. Jednakże majętniejsi, będący w chwilowej potrzebie, zaciągając u bractwa pożyczki gwarantowane fantami, godzili się na znaczne niekiedy ich oprocentowanie. Płynące z tych transakcji procenty konfraternia przeznaczała na jałmużny dla ubogich, zakup drewna, odzieży czy trumien dla zmarłych biedaków ${ }^{209}$.

Przy krakowskim bractwie miłosierdzia Piotr Skarga z innym jezuitą Marci-

${ }^{203}$ Kumor, Kościelne stowarzyszenia, s. 521-522; tenże, Kościelne stowarzyszenia, s. 324, 326; Karpiński, Pauperes, s. 320; Nowacki, Dzieje archidiecezji, s. 665; Kurczewski, Biskupstwo, s. 353; Krętosz, Organizacja, s. 266.

${ }^{204}$ W. Partyka, Bank Pobożny w Zamościu w XVII-XVIII wieku, ABMK, 89 (2008) s. 333.

${ }^{205}$ Kumor, Kościelne stowarzyszenia, s. 521; tenże, Kościelne stowarzyszenia, s. 325-326; Kuźmak, Natoński, Bractwo Miłosierdzia, kol. 1022.

${ }^{206}$ Nowacki, Dzieje archidiecezji, s. 662; Karpiński, Pauperes, s. 268, 316, 319-320, 322; Chodyński, Bractwo, s. 575; Z. Podgórska-Klawe, Szpitale warszawskie 1388-1945, Warszawa 1975, s. 33-34, 48 .

${ }^{207}$ Góralski, Szpitale na Lubelszczyźnie, s. 155, 164.

${ }^{208}$ Kurczewski, Biskupstwo, s. 356.

${ }^{209}$ Lukaszewicz, Krótki opis, s. 151. 
nem Łaszczem zaprowadzili w 1588 r. tzw. skrzynkę św. Mikołaja, do której zbierano ofiary na posag dla ubogich panien zamierzających wyjść za mąż lub wstąpić do klasztoru. Od strony materialnej ufundował ją starosta krakowski Mikołaj Zebrzydowski, który poprzez zapomogi i posagi chciał uchronić biedne dziewczęta i młode wdowy od zejścia na złą drogę i prostytucji ${ }^{210}$. Fundacją posagową kierowało też wileńskie bractwo miłosierdzia założone przez P. Skargę ${ }^{211}$.

Bractwo miłosierdzia P. Skargi posiadało swoje władze. Honorowe miejsce w bractwie zajmował patron (protektor), z reguły duchowny, pełniący funkcje reprezentacyjne i nadzorcze. Obok niego najważniejszy był senior inaczej starszy, w którego gestii leżała kontrola podległych mu konfratrów i wybieralnych urzędników, organizacja i prowadzenie schadzek, nadzór nad rachunkami korporacji ${ }^{212}$. Seniorowi pomagało dwóch radnych (asesorów), którzy podczas nieobecności starszego zastępowali go w przewodniczeniu schadzkom ${ }^{213}$. Kolejne miejsce w hierarchii konfraterni zajmował szafarz, zawiadujący kasą i wydzielający zapomogi. Podlegał on nadzorowi dwóch prowizorów, kierujących jednocześnie w wypadku bractwa warszawskiego szpitalem św. Łazarza. Rekrutacją pensjonariuszy do tego szpitala prowadzili czterej wizytatorzy, zajmujący się również wyszukiwaniem nędzarzy wymagających finansowego wsparcia ${ }^{214}$. Odwiedzali oni domy ubogich i chorych, zbierali informacje o ludziach potrzebujących pomocy. W pierwszej kolejności kierowali się do rodzin wielodzietnych oraz do tych, którzy wpadli w ubóstwo w wyniku życiowych nieszczęść ${ }^{215}$. Z kolei kapelan bracki (promotor) otaczałopieką duszpasterskączłonków korporacjiipodległychjej biedaków. WWarszawie zobowiązany był także do wysłuchiwania skarg podopiecznych szpitala św. Łazarza i napominania odpowiedzialnych za nadużycia. Założenie szpitala spowodowało konieczność utrzymywania przez bractwo personelu pomocniczego: okresowo lekarza i cyrulika, posługaczy itp. ${ }^{216}$. Niektóre bractwa mialy własne kaplice ${ }^{217}$. Konfraternia krakowska posiadała zarówno ojca duchownego, jak i kapłana brackiego. Pierwszy z nich prowadził modlitwę w czasie schadzek i odprawiał mszę świętą bracką, zaś kapłan bractwa, wybierany przez wspólnotę, celebrował dwie msze tygodniowo (jedną za zmarłych członków, drugą za żyjących), msze w niedziele i święta oraz tygodniowe msze brackie i roraty ${ }^{218}$. Kolej-

${ }^{210}$ A. Karpiński, Fundacje posagowe $w$ dużych miastach Rzeczypospolitej $w$ XVI-XVIII wieku, „Kwartalnik Historyczny”, 105 (1998) z. 1, s. 10; J. Tazbir, Piotr Skarga. Szermierz kontrreformacji, Warszawa 1978, s. 208; S. Chodyński, Bractwo, s. 575; Łukaszewicz, Krótki opis, s. LVII.

${ }^{211}$ Karpiński, Fundacje posagowe, s. 10, J. Kurczewski, Biskupstwo, s. 367.

${ }^{212}$ Karpiński, Pauperes, s. 316.

${ }^{213}$ P. Skarga, Bractwo Miłosierdzia w Krakowie u św. Barbary zaczete Roku Panskiego 1584 Miesiaca Octobra a w roku 1592 w Warszawie Miesiaca septembra u św. Jana przyjęte, Warszawa 1763, s. 60.

${ }^{214}$ Karpiński, Pauperes, s. 316.

${ }^{215}$ Skarga, Bractwo Miłosierdzia, s. 65.

${ }^{216}$ Karpiński, Pauperes, s. 316.

${ }^{217}$ Lwowskie bractwo miłosierdzia posiadało taką kaplice w katedrze, przy której działało. Krętosz, Organizacja, s. 283.

${ }^{218}$ Skarga, Bractwo Mitosierdzia, s. 57-60. 
nym urzędnikiem był pisarz, prowadzący aż cztery księgi. Pierwsza zawierała: rejestr członków, druga - spis jałmużn z nazwiskami ofiarodawców, trzecia - daty wpływu i wydania jałmużn, czwarta - spisane obowiązki konfratrów i urzędników oraz dekrety i akta brackie. Jego obowiązkiem było także odwiedzanie w ciągu tygodnia 3-4 ubogich i prezentowania bractwu ich sytuacji ${ }^{219}$. W XVI -wiecznych bractwach miłosierdzia był jeszcze w zarządzie sługa bracki, który pomagał urzędnikom i uczestniczył w schadzkach. Pilnował odprawiania mszy za zmarłych współbraci, a także pamiętał o świecach na mszach brackich ${ }^{220}$. Kolegialnym ciałem bractw miłosierdzia były comiesięczne schadzki, gromadzące wszystkich członków i urzędników brackich ${ }^{221}$.

Najbardziej naturalnym i powszechnym źródłem dochodu bractw miłosierdzia były składki członków i zebrane jałmużny. Nie one jednak stanowiły o budżecie organizacji. W bractwie warszawskim decydujące znaczenie posiadały darowizny w postaci nieruchomości: gruntów, ogrodów, kamienic, często wydzierżawiane za roczny czynsz. Ważnym źródłem dochodów konfraterni były legaty pieniężne, przede wszystkim ze strony szlachty i magnaterii oraz dużo skromniejsze ze strony mieszczaństwa i duchowieństwa ${ }^{222}$. Dobroczyńcy przeznaczali z reguły swoje legaty na konkretną sferę działalności: na samo bractwo, bądź podległy mu szpital św. Łazarza. W związku z wielokierunkową działalnością charytatywną bractw, często dzielono ich fundusze z przeznaczeniem na konkretny cel. W ramach ogólnego funduszu arcybractwa i banku krakowskiego istniały więc m.in. fundusze: jałmużniczy, banku pobożnego, posagowy dla ubogich dziewcząt wychodzących za mąż, szpitalny i inne ${ }^{223}$.

Fundatorami bractw miłosierdzia i banków pobożnych byli najczęściej możnowładcy duchowni i świeccy ${ }^{224}$. Sam Piotr Skarga ufundował obie instytucje w Krakowie ${ }^{225}$, Warszawie ${ }^{226}$ i Wilnie ${ }^{227}$, a prymas Stanisław Karnkowski w Łowi$\mathrm{czu}^{228}$. Bank pobożny w Rzeszowie powstał w wyniku realizacji testamentu kanonika Łukasza Doctoriusa, który cały swój majątek przeznaczył na realizację celów charytatywnych, m.in. w swoim rodzinnym mieście ${ }^{229}$. Z kolei bank pobożny w Zamościu ufundował kanclerz Jan Zamoyski. Bank miał udzielać pożyczek pod zastaw uczącej się młodzieży (zwłaszcza w Akademii Zamojskiej) i rzemieślnikom $^{230}$.

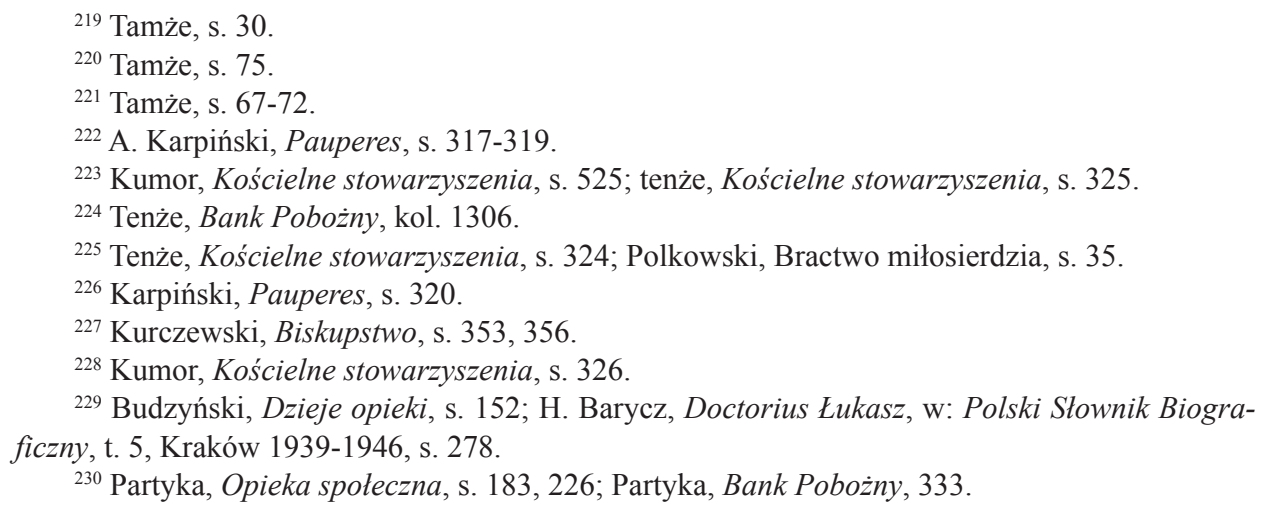




\section{BRACTWA MILOSIERDZIA MICHALA JERZEGO PONIATOWSKIEGO}

W dziejach bractw miłosierdzia można wyróżnić dwa odrębne okresy rozwoju, a zarazem dwa różne organizacyjnie i koncepcyjnie stowarzyszenia, choć noszące te sama nazwę. Jak już wspomniano bractwa propagowane i zakładane przez P. Skargę, po śmierci swego orędownika przeżywały pogłębiający się stale kryzys, a po kasacie popierających je jezuitów w 1773 r. oraz wskutek braku odpowiedniego uposażenia i trudnej sytuacji politycznej kraju, niemal zupełnie upadły, przechodząc pod zarząd władz diecezjalnych ${ }^{231}$. Około dwieście lat później od pojawienia się pierwszych bractw P. Skargi, w ramach reformy kościelnej działalności charytatywnej, podjętej w myśl założeń i tendencji oświeceniowych, dążących do nadania instytucjom kościelnym charakteru utylitarnego, powrócił do idei bractw miłosierdzia biskup, późniejszy prymas Michał Jerzy Poniatow$\mathrm{ki}^{232}$. Najpierw jako koadiutor diecezji płockiej, potem ordynariusz płocki, polecił je tworzyć we wszystkich parafiach w miejsce konfraterni wówczas kasowanych przez władze państwowe. Nakaz ten powtórzył później jako biskup krakowski i arcybiskup gnieźnieński ${ }^{233}$. We wszystkich więc diecezjach, gdzie sprawował władzę, lansował i polecał zakładanie tych charytatywnych organizacji. Nie miały to być jedne z wielu bractw, lecz bractwa, którym inne miały być „subordynowane”. Poniatowski inkorporował do nich wszystkie dotychczasowe konfraternie dewocyjne wraz ze swymi funduszami, wykorzystywanymi odtąd do celów nie tyle pobożnych, ile użytecznych społecznie ${ }^{234}$.

Decyzję ustanowienia nowego bractwa miłosierdzia obwieszczano wiernym w niedzielę lub inne święto w miejscowych kościołach ${ }^{235}$. Wprowadzano je uroczyście przy licznych księżach, nieraz „z muzyką i przy biciu dzwonów”, często podczas misji parafialnych, prowadzonych np. przez kapucynów, którzy oficjalnie bractwa zaprowadzali ${ }^{236}$. Powrót do bractw miłosierdzia $i$ ich odnowienie były próbą wprowadzenia na szerszą, masową skalę zinstytucjonalizowanej formy dobroczynności w oparciu istniejące wzory, dostosowane do nowej sytuacji ${ }^{237}$. Odrodzone $\mathrm{w}$ dobie pierwszego rozbioru bractwa miłosierdzia, w porównaniu do wcześniejszego prototypu, z uwagi na obligatoryjność zakładania, posiadały bar-

${ }^{231}$ Kuźmak, Natoński, Bractwo Miłosierdzia, kol. 1022.

${ }^{232}$ Flaga, Bractwa religijne i przejawy, s. 61.

${ }^{233}$ Tenże, Rodzaje, s. 87-85; Kumor, Bank Pobożny, kol. 130; M.J. Poniatowski, Ustanowienie Bractwa Miłosierdzia po parafiach $w$ dyecezyi płockiey, Warszawa 1777; tenże, Ustanowienie Bractwa Miłosierdzia po parafiach w dyecezyi krakowskiey, Warszawa 1784; tenże, Ustanowienie Bractwa Miłosierdzia po parafiach archi-diecezyi gnieźnieńskiey, Łowicz 1787. W tekście w nawiasach daty wydania rozporządzeń na poszczególne diecezje.

${ }^{234}$ Litak, Bractwa, s. 502.

${ }^{235}$ Poniatowski, Ustanowienie [...] płockiey, s. 13; tenże, Ustanowienie [...] krakowskiey, s. 13; tenże, Ustanowienie [...] gnieźnieńskiey, s. 13.

${ }^{236}$ Flaga, Bractwa religijne i przejawy, s. 50-51; M. Grzybowski, Kościelna działalność Michata Jerzego Poniatowskiego biskupa płockiego 1773-1785, w: Studia z historii Kościoła w Polsce, t. 7, Warszawa 1983, s. 181.

${ }^{237}$ Flaga, Bractwa religijne i przejawy, s. 61-62. 
dziej powszechny i uniwersalny charakter, realizowały bardziej różnorodną działalność chrytatywno-społeczną, również edukacyjną.

Według Poniatowskiego bractwo i parafia stanowiły jedność, części ze sobą połączone, które oddzielnie nie mogły istnieć. W tę wspólnotę włączeni byli wszyscy parafianie, duchowni i bracia, kierujący się działaniem na rzecz dobra, pożytku i szczęścia wszystkich jej uczestników. Jednocześnie istniała w wspólnocie hierarchia, w której każdy był odpowiedzialny za coś innego i przed kimś innym $^{238}$. Wizja i model bractwa miłosierdzia, zawierały więc $\mathrm{w}$ sobie nową koncepcję roli i znaczenia parafii, w dużym stopniu podporządkowanej realizacji celów wyznaczonych przez biskupa nowym stowarzyszeniom.

Motywem, jaki skłonił Poniatowskiego do zajęcia się reformą opieki społecznej i przeprowadzenia jej o restaurowane bractwa miłosierdzia, była osobista obserwacja i świadomość wielkiej skali ludzi potrzebujących, włóczęgów i żebraków oraz przekonanie o niedoskonałości i nieskuteczności dotychczasowego systemu opieki społecznej i szpitalnictwa. W momencie gdy w 1777 r. wydawał Ustanowienie o Bractwie Miłosierdzia... dla diecezji płockiej, tamtejsze nieliczne szpitale nie posiadały stałych funduszy i źródeł utrzymania. Były to jak je określał schronienia bez opatrzenia, słabo urządzone pod względem sprzętów, środków do życia i warunków sanitarnych. Brakowało też odpowiednich fundatorów i dobroczyńców, a tymczasem pojawiało się tam coraz więcej tułaczy i szukających schronienia ${ }^{239}$. W przekonaniu biskupa najbardziej odpowiednim środkiem do przezwyciężenia tej sytuacji miała być instytucja bractwa miłosierdzia $\mathrm{w}$ parafiach $^{240}$. Jego koncepcja pomocy potrzebującym, m.in. chorym i dzieciom w oparciu o bractwa znalazła poparcie i akceptację, o czym świadczy opinia: „Troskliwy o dobro swey Dyecezyi Pastaerz Xiąże Biskup Płocki przełożył, że bardzo potrzebne jest ustanowienie Bractwa, któreby dbało nie tylko o chorych potrzebujących pomocy, ale też i o dzieci pozostające bez pomocy i nic lepszego dla zaradzenia nie dało się uczynić" 241 . Ustanawiane z inicjatywy Poniatowskiego bractwo popierała Stolica Apostolska, wyrażając nadzieję, że również po objęciu rządów w archidiecezji gnieźnieńskiej będzie on kultywował w nowej „Owczarni” wcześniejsze inicjatywy charytatywne ,[...] dla dobra Owieczek Naszych duchowego i doczesnego najlepszym sposobem [...]"242.

Trudno powiedzieć, jak szybko i w jakiej skali postępował rozwój bractw propagowanych przez Poniatowskiego, który nakazywał wprowadzać je natychmiast po objęciu rządów w poszczególnych diecezjach. Powstawały one jeśli nie wyłącznie, to przede wszystkim, na terenach przez niego administrowanych; chro-

${ }^{238}$ A. Kozik, Reforma opieki społecznej Michała Jerzego Poniatowskiego w drugiej połowie XVIII wieku, Lublin 2012 (mps, Archiwum KUL), s. 59-58; Poniatowski, Ustanowienie [...] w dyecezyi płockiey, s. 63-64.

${ }^{239}$ Poniatowski, Ustanowienie [...] ptockiej, s. 2.

${ }^{240}$ Tamże, s. 5.

241 J.A. Archetti, List Xiędza Nuncyusza potwierdzający moca Stolicy Apostolskiey Bractwo Miłosierdzia nadaniem onemuż Odpustów po Parafiach Dyecezyi Płockiey, 1777, s. 276, Biblioteka Uniwersytecka KUL, sygn. XVIII 6849.

${ }^{242}$ Poniatowski, Ustanowienie [...] gnieźnieńskiey, s. 2. 
nologicznie najpierw w diecezji płockiej. Podczas wizytacji z 1781 r. w dekanacie makowskim w 9 parafiach było 6 bractw miłosierdzia, zaś trzy lata wcześniej (1778) w dekanacie wyszkowskim na 13 parafii, tylko jedno ${ }^{243}$. Łącznie na tym terenie w około co trzeciej parafii funkcjonowało bractwo, co na tak krótki okres, jaki minął od jego ustanowienia, świadczy o niezłej adaptacji nowych stowarzyszeń. Akta całej wizyty generalnej z $1781 \mathrm{r}$. zanotowały, że bractwo erygowano w 64 parafiach ${ }^{24}$. Przeważa opinia, że nie spełniły one na terenie diecezji płockiej pokładanych w nich nadziei, nie natrafiły tam na sprzyjający grunt, a ich idea nie została w pełni zaakceptowana przez społeczności parafialne. Bractwa, które miały zapobiegać i łagodzić skutki nędzy, nie mogły się należycie rozwijać z powodu niedostatku i złej sytuacji materialnej parafii oraz mieszkańców, niekiedy braku pomieszczenia na szpital, który był podstawą skutecznej ich działalności. Kolejnym powodem stającym na przeszkodzie w zaprowadzeniu bractwa były „odległości i prostota" parafian oraz ich brak zrozumienia i niechęć do angażowania się w działalność charytatywną. Przykładowo w parafii Grajewo (dek. Wąsocz) bractwo po dwóch latach istnienia zakończyło swoją działalność z powodu braku zainteresowania ze strony parafian. Jeszcze jedną przeszkodą był nieprzychylny do bractwa miłosierdzia stosunek właścicieli dóbr. W parafii Długosiodło w dekanacie wyszkowskim właściciel uważał, że mieszkający tam parafianie, w komplecie ludność wieśniacza, sami potrzebują pomocy, w związku z tym zakazał pod karą plag wpisywania się do bractwa ${ }^{245}$. Mimo wszystko w drugiej połowie XVIII w. w diecezji tej liczącej ok. 340 parafii, istniało ponad 100 bractw miłosierdzia ${ }^{246}$. Oznacza to, że średnio w co trzeciej parafii (ok. 30\%) udało się zaszczepić ideę Poniatowskiego. Bo nie ulega wątpliwości, że niemal wszystkie te konfraternie założone zostały dopiero w dobie jego rządów ponad dziesięcioletnich rządów (1773-1775).

W podobnej skali oświeceniowe bractwa miłosierdzia występowały w archidiakonacie lubelskim - części diecezji krakowskiej, którą również zarządzał Poniatowski po przejściu z biskupstwa płockiego. Na ogólną liczbę 91 istniejących w nim parafii pod koniec XVIII wieku, w 29 występowały wspomniane konfraternie, z tym że aż 25 miało rodowód z czasów, gdy diecezją kierował wymieniony biskup reformator, lub o kilka lat późniejszych. Zatem bractwa miłosierdzia posiadało około $32 \%$ (ze starymi) lub 27,5\% (wyłącznie nowe) parafii archidiakonatu. Bractwa te funkcjonowały zarówno w parafiach miejskich (23), jak też wiej-

${ }^{243}$ M. Grzybowski, Materiały do dziejów ziemi płockiej, Ziemia makowska, t. 6, Płock 1991, s. 88 .

${ }^{244}$ Tenże, Kościelna działalność, s. 183; tenże, Życie religijno-moralne $w$ diecezji płockiej w czasach rząów biskupa Michała Poniatowskiego (1773-1785), „Studia Płockie, 4 (1976) cz. II, s. 123.

${ }^{245}$ Flaga, Działalność charytatywna, s. 382-284; tenże, Bractwa religijne i przejawy, s. 64-65; tenże, Bractwa religijne w Rzeczypospolitej, s. 210-212.

${ }^{246}$ Flaga, Bractwa religijne i przejawy, s. 37; W. Graczyk, Płocka diecezja, EK, t. 15, Lublin 2011, kol. 859. Ten drugi podaje, że taka liczba bractw istniała już w 1773 r., co nie jest rzeczą prawdopodobną. 
skich $(22)^{247}$. Działalność konfraterni miłosierdzia nie ograniczała się wyłącznie do parafii i ośrodków miejskich. Dość częsta obecność bractw w parafiach wiejskich wynikała z zakładanej przez Poniatowskiego polityki powszechności tych instytucji. W Wąwolnicy doszło w 1786 r. do ponownego utworzenia bractwa miłosierdzia, po szybkim upadku przed stu pięćdziesięciu laty bractwa P. Skargi. Absolutna większość bractw miłosierdzia związana była z kościołami parafialnymi, a jedynie zaprowadzone w 1786 r. charytatywne bractwo w Łęcznej działało przy prepozyturalnym kościele szpitalnym Św. Ducha ${ }^{248}$. W okresie wcześniejszym do kościołów szpitalnych przyłączono jeszcze stare bractwa miłosierdzia w Ostrowie i Lublinie ${ }^{249}$.

Nic nie można powiedzieć na temat ewentualnego rozwoju bractw miłosierdzia $\mathrm{w}$ archidiecezji gnieźnieńskiej. Fakt krótkiego sprawowania tam rządów przez Poniatowskiego, tuż przed ostatecznym upadkiem państwa polskiego, nie pozwolił mu na szersze rozwinięcie autorskiej inicjatywy. Pojawia się pytanie, czy nowe bractwa mogły też powstawać w pozostałych diecezjach polskich nie objętych administracją Poniatowskiego. Sporadycznych przypadków ich recepcji na tych terenach nie można całkowicie wykluczać. Na pewno nie występowały one we wschodnich diecezjach: kamienieckiej, żmudzkiej, wileńskiej i łuckiejejo. Dopiero w 1799 r. biskup Jan Nepomucen Kossakowski polecił je zakładać na Litwie $^{251}$, reaktywując i odnawiając zarazem stare bractwo założone przed dwustu laty przez Piotra Skargę w stolicy diecezji ${ }^{252}$. Przez cały okres XVI-XVIII w. nie było też żadnych bractw miłosierdzia w diecezji warmińskiej, z kolei w archidiecezji lwowskiej w XVIII w. skończyło swój żywot bractwo P. Skargi i nie zostało później odnowione ${ }^{253}$.

Zdarzało się, że XVIII-wieczne bractwa miłosierdzia przyłączano do innych wspólnot brackich istniejących przy tym samym kościele. Sytuacja taka miała miejsce w Wieluniu, gdzie działające przy kościele parafialnym bractwo miłosierdzia złączono w 1787 r. z tamtejszą konfraternią różańcową. Pomimo tego nadal

${ }^{247}$ Obliczono na podstawie: Flaga, Bractwa religijne w archidiakonacie lubelskim do końca XVIII wieku, s. 302, 327, 328-330; tenże, Działalność charytatywna, s. 382-284, s. 385; tenże, Bractwa religijne $w$ Rzeczypospolitej, s. 213.

${ }^{248}$ Flaga, Bractwa religijne $w$ archidiakonacie lubelskim do końca XVIII wieku, s. 318, 324327,343 .

${ }^{249}$ Było o tym wcześniej. Flaga, Bractwa religijne w archidiakonacie lubelskim do końca XVIII wieku, s. 343.

${ }^{250}$ J. Flaga, Bractwa religijne w diecezji kamienieckiej, s. 616; tenże, Informacje o bractwach s. 42-47; E. Krawczyk, Bractwa religijne w niektórych dekanatach diecezji wileńskiej w II połowie XVIII wieku, Lublin 2001, (mps Archiwum KUL); Królik, Organizacja diecezji. Jedno z opracowań podaje, że w Łucku bractwo miłosierdzia, chyba jeszcze XVI-XVII-wieczne, zmieniło w XIX w. swój status administracyjny (Kuźmak, Natoński, Bractwo Miłosierdzia, kol. 1022). Inne prace, zwłaszcza, najważniejsza Królika, nic nie wspominają o bractwie miłosierdzia w Łucku.

${ }^{251}$ Kuźmak, Natoński, Bractwo Miłosierdzia, kol. 1022.

${ }^{252}$ Zob. wcześniejsze rozważania: Kurczewski, Biskupstwo, s. 356.

${ }^{253}$ Kopiczko, Ustrój i organizacja, s. 226-229; Krętosz, Organizacja, s. 275-279. 
jednak działało, zachowując własną strukturę organizacyjną ${ }^{254}$. Do fuzji bractwa miłosierdzia założonego przez Poniatowskiego z bractwem Pocieszenia N. Panny doszło też w parafii Kamionka na Lubelszczyźnie. Od tego momentu obie konfraternie, mające ten sam cel wspierania i żywienia ubogich, obierały wspólne władze. W takiej podwójnej konfiguracji bractwo funkcjonowało jeszcze w latach trzydziestych XIX w. ${ }^{255}$

Śmierć Poniatowskiego (1794), rychły upadek państwa polskiego oraz związane z tym osłabienie struktur i pozycji Kościoła katolickiego, przerwały dalszy rozwój tych stowarzyszeń, niektóre jednak kontynuowały dalej swoją działalność. Bractwo miłosierdzia w Kurowie niedaleko Lublina, założone przez tamtejszego prepozyta Grzegorza Piramowicza w odpowiedzi na list M.J. Poniatowskiego, posiadało jeszcze w 1802 r. 1380 złp. funduszu ,ze składek parafian w pieniądzach i zbożu". Kapitał ten jednak nie narastał, ponieważ dawano z niego pożyczki ubogim ludziom. W 1809 r., zarządzający kasą funduszu brackiego ks. Krasuski, wypożyczył całą sumę ,tytułem wsparcia różnym ubogim bez żadnej hipoteki”, którzy z nielicznymi wyjątkami kwoty tej nie zwrócili. Wobec tego, jak pisał wizytator w 1830 r., ,teraz od lat dwudziestu kilku żadnej jałmużny na ten cel nie ma, więc bractwo ustało"256. W Krakowie np. bractwo miłosierdzia zreformowane przez biskupa Feliksa Turskiego, poddano pod zwierzchnictwo i protektorat archiprezbitera kościoła Mariackiego. W XIX w. w większych miastach ich funkcje przejęły też towarzystwa dobroczynności, a w Galicji Bractwo Czynnej Miłości ${ }^{257}$.

Preferowano osoby posiadające dobra w parafii, które według Poniatowskiego najlepiej wykonywały powierzone im zadania i miały wyjątkową „litość nad nędzą i niedoostatkiem". Do bractwa można się było zapiać 29 czerwca w dzień św. Piotra i Pawła. Tylko w szczególnych okolicznościach pozwalano to zrobić $\mathrm{w}$ innym terminie ${ }^{258}$. Zalecano, aby nikt $\mathrm{z}$ przyjętych do bractwa nie odchodził z niego bez poważnej przyczyny, nawet gdy wyjeżdżał miał obowiązek znaleźć zastępstwo na swoje miejsce czy stanowisko, a także zawiadomić o tym kapłana. Każdy z braci musiał posiadać wiedzę o stanie żebractwa oraz o ilości osób chorych w parafii pozostających bez pomocy, miał też zadanie odnajdywać potrzebujących i udzielać im pomocy. Chodziło przede wszystkim o osoby, które ze względu na kalectwo lub wstyd nie są w stanie sami zwrócić się do bractwa o wsparcie.

${ }^{254}$ Flaga, Dziatalność charytatywna, s. 385; tenże, Bractwa religijne w Rzeczypospolitej, s. $213-214$.

${ }^{255}$ Archiwum Archidiecezjalne w Lublinie (AAL), Rep 60 A 205, Visitatio Ecclesiarum Dioecesis Lublinensis tempore Episcopatus illmi Josephi Marcellini Dzięcielski (anno 1830) peracta. Vol. I, s. 442v; AAL, Rep 60 A 164, Actus Visitationis Generalis Decanatus parczoviensis ab [...] Adalberto Leszczyc Skarszewski Episcopo Helmensi et LublinensiPeractae Anno Domini 1800, s. 288.

${ }^{256}$ AAL, Rep 60 V 2, Wizyty Dziekańskie Kościołów Diecezyi Lubelskiej z r. 1827, s. 257-258; AAL, Rep 60 A 205, Visitatio Ecclesiarum Dioecesis Lublinensis, s. 180v-181.

${ }^{257}$ Kuźmak, Natoński, Bractwo Miłosierdzia, kol. 1022; Budzyński, Dzieje opieki, s. 157.

${ }^{258}$ A. Kozik, Reforma opieki społecznej Michała Jerzego Poniatowskiego w drugiej połowie XVIII wieku, Lublin 2012, s. 54 (mps, Archiwum KUL); Poniatowski, Ustanowienie [...] ptockiey, s. 17-19; tenże, Ustanowienie [...] gnieźnieńskiey, s. 18-20. 
Powinnością braci było odróżnianie fałszywych potrzebujących od prawdziwych. Po zidentyfikowaniu mistyfikacji ubóstwa, mieli oni oddalać takich „biedaków” z parafii przy użyciu pomocy urzędowej. Poniatowski był świadom, że duża część osób proszących o jałmużnę mogła podjąć pracę i samodzielnie funkcjonować, wiedział, że przez nich cierpią i giną z nędzy prawdziwie potrzebujący, apelował więc do braci i sióstr o dokładne przyglądanie się i weryfikowanie, kto naprawdę zasługuje na pomoc ${ }^{259}$.

Według Poniatowskiego głównym zadaniem bractwa miłosierdzia było „pomagać bliźniemu różnemi godziwemi sposobami we wszelkich jego przygodach"260. Biskup zobowiązał członków bractwa do ratowania bliźnich, ubogich i chorych parafian nie mających żadnego wsparcia i środków do życia, a w szczególności niesienia pomocy najbardziej bezbronnym - pozostającym bez opieki, głodnym, dotkniętym chorobami dzieciom. Zwrócił szczególną uwagę na ich wychowanie i przekazywanie odpowiednich treści ${ }^{261}$. Działalność bractw miała uwzględnić dwa aspekty życia ludzkiego. Obok niesienia pomocy materialnej potrzebującym, miały tymże „służyć koło potrzeb duszy”262. Dlatego nowe bractwa starały się spełniać jednocześnie dwa zadania: zapobiegać nędzy i żebractwu oraz pomagać w rozwijaniu i umacnianiu życia religijnego wśród ich członków, mieszkańców szpitali i parafian ${ }^{263}$.

To pierwsze zadanie, tzn. działalność charytatywną bractwa miały realizować poprzez zakładanie i prowadzenie szpitali oraz zbieranie jałmużny. Tworzenie szpitali stało się potrzebą konieczną i naglącą, ponieważ, jak pisał Poniatowski, zarówno w diecezji płockiej, jak i w całym kraju „bardzo mało jest miejsc takich, gdzieby dla ubogich i chorych jakie wspomożenie obmyślane było"264. Według zaleceń biskupa, szpital miał powstać przy każdym kościele parafialnym ${ }^{265}$. W przeciwieństwie do okresu potrydenckiego nie był on agendą parafii, a częścią poddaną bractwu, które należało założyć w każdym okręgu parafialnym ${ }^{266}$. Dlatego proboszczowie szpitalni, o ile nie byli jednocześnie kapelanami bractwa, posiadali obowiązek porozumiewania się w sprawach szpitala i jego pensjonariuszy $\mathrm{z}$ urzędnikami bractwa ${ }^{267}$. Nowe szpitale, według zaleceń dla diecezji płockiej, miały posiadać dwie lub cztery izby, by zapewnić w pierwszej kolejności izolację

${ }^{259}$ Kozik, Reforma, s. 60-61; Poniatowski, Ustanowienie [...] płockiey, s. 20-23; tenże, Ustanowienie [...] krakowskiey, s. 19-23; tenże, Ustanowienie [...] gnieźnieńskiey, s. 21-24.

${ }^{260}$ Poniatowski, Ustanowienie [...] gnieźnieńskiey, s. 21-24

${ }^{261}$ Tamże, s. 7-8; tenże, Ustanowienie [...] płockiey, s. 6.

${ }^{262}$ Flaga, Bractwa religijne i przejawy, s. 62; tenże, Bractwa religijne w Rzeczypospolitej, s. 35-36.

${ }^{263}$ Flaga, Działalność charytatywna, s. 380; tenże, Bractwa religijne i przejawy, s. 63

${ }^{264}$ Tenże, Bractwa religijne i przejawy, s. 62.

${ }^{265}$ Poniatowski, Ustanowienie [...] płockiey, s. 8; tenże, Ustanowienie [...] gnieźnieńskiey, s. 9-10.

${ }^{266}$ Por. Flaga, Bractwa religijne i przejawy, s. 62.

${ }^{267}$ Poniatowski, Ustanowienie [...] płockiey, s. 75-76; tenże, Ustanowienie [...] gnieźnieńskiey, s. 63-64. 
kobiet i mężczyzn, a następnie zdrowych $\mathrm{i}$ chorych ${ }^{268}$. W diecezji krakowskiej w domu brackim o czterech izbach, jedną miały zajmować zdrowe ubogie kobiety, drugą chore ubogie kobiety, dwie kolejne zdrowi i chorzy ubodzy mężczyźni, natomiast w archidiecezji gnieźnieńskiej, oprócz chorych, w części takiego budynku miało być miejsce dla nauczyciela i dla uczących się dzieci ${ }^{269}$. W sytuacji, gdy szpitale parafialne były zbyt małe, bractwo miało organizować je w porozumieniu $\mathrm{z}$ właścicielami dóbr w większych, nieparafialnych wioskach. Z kolei małe szpitale w niewielkich parafiach zalecano łączyć w większe, zarazem wygodniejsze i bardziej obszerne ${ }^{270}$. Szpitalem głównym, któremu podlegały wszystkie inne miał być Szpital Generalny. W diecezji płockiej taki charakter posiadały trzy szpitale prowadzone przez siostry miłosierdzia: szpital Św. Trójcy w Płocku, w Pułtusku, w Szczuczynie. Do nich zamierzano odsyłać chorych z wszystkich miejscowych szpitali parafialnych, w których nie mogli znaleźć odpowiedniej opieki. Szpital w Płocku założył w 1784 r. i uposażył osobiście sam biskup, który wzbogacił też bazę materialną szpitala pułtuskiego. On też podźwignął z zaniedbania jedyną w tym regionie instytucję pożyczkową mons pietatis ${ }^{271}$.

Organizacja szpitalnictwa w pomyśle Poniatowskiego była więc hierarchiczna, podobnie jak reformowanego w tym samym czasie przez Komisję Edukacji Narodowej, szkolnictwa. Pod względem wielkości, warunków lokalowych, poziomu opieki oraz możliwości leczenia najniżej stały szpitale wiejskie, najwyżej szpitale generalne, między nimi plasowały się szpitale parafialne. Wobec tego najbardziej chorych należało umieszczać w szpitalach generalnych, ewentualnie parafialnych, zaś lżej chorych, pielgrzymów i ubogich w przytułkach wiejskich. Stwarzało to namiastki swego rodzaju specjalizacji szpitali, umożliwiające przenoszenie pensjonariuszy, w zależności od ich stanu fizycznego, z jednej do drugiej placówki ${ }^{272}$. Postulowane rozwiązanie miało przyczynić się do lepszej opieki medycznej, możliwej do zagwarantowania w większych szpitalach, a także zapobiec dużej śmiertelności pensjonariuszy małych przytułków parafialnych pozbawionych opieki lekarskiej. Miało to jednocześnie zwiększać możliwości leczenia, dostęp do lekarzy, zmniejszać śmiertelność chorych ${ }^{273}$. Rozpoczęta jesienią $1777 \mathrm{r}$. $\mathrm{w}$ diecezji płockiej akcja z bractwem miłosierdzia przyczyniła się do poprawy stanu ilościowego szpitali parafialnych i panujących w nich warunków w zakresie opieki i aprowizacji. Od 1775 do 1781 r. liczba istniejących tam szpitali-przytułków wzrosła o blisko połowę z 65 do $105^{274}$.

Życie szpitalników nadzorować miała wyznaczona spośród nich przez bra-

${ }^{268}$ Tenże, Ustanowienie [...] płockiey, s. 8-9; tenże, Ustanowienie [...] gnieźnieńskiey, s. 9-10.

${ }^{269}$ Tenże, Ustanowienie [...] krakowskiey, s. 9-10; tenże, Ustanowienie [...] gnieźnieńskiey, s. $10-11$.

${ }^{270}$ Tenże, Ustanowienie [...] płockiey, s. 75-76; tenże, Ustanowienie [...] gnieźnieńskiey, s. $62-63$.

${ }^{271}$ Kozik, Reforma, s. 71; Poniatowski, Ustanowienie [...] plockiey, s. 70-71; Grzybowski, Kościelna działalność, s. 183-185; tenże, Życie religijno-moralne, s. 123-125.

${ }^{272}$ Poniatowski, Ustanowienie [...] płockiey, s. 71-72.

${ }^{273}$ Tamże, s. 68-69; tenże, Ustanowienie [...] gnieźnieńskiey, s. 59-60.

${ }^{274}$ Grzybowski, Kościelna działalność, s. 183; tenże, Życie religijno-moralne, s. 123. 
ctwo osoba, ich sposób zachowania, wypełnianie codziennych prac i praktyk religijnych nadzorowała wyznaczona przez bractwo „nayzdatnieysza” osoba, która miała obowiązek mieszkania w szpitalu. Wyrazem zwierzchności konfraterni nad szpitalem było wyznaczanie przez urzędników brackich kapłana szpitalnego ${ }^{275}$. Uprawnienia zwierzchnie bractwa $\mathrm{w}$ stosunku do szpitali wyrażały się przede wszystkim w obowiązku corocznego wizytowania tych instytucji przez prokuratora i kapelana brackiego ${ }^{276}$. Rola bractwa nie ograniczała się tylko do funkcji nadzorczo-kontrolnej; jego członkowie angażowali się w pomoc szpitalowi i jego mieszkańcom. Mieli oni czuwać nad zapewnieniem pensjonariuszom posługi religijnej i sakramentalnej. Zarazem bractwo określało obowiązki szpitalnikom, dbało o dokształcanie się i ugruntowywanie wiedzy religijnej ${ }^{277}$. Jego członkowie zajmowali się nauczaniem prawd wiary także wśród ludzi prostych poza szpitalem, mogli też uczyć czytania, pisania i rachunków ${ }^{278}$. Dlatego władze bractwa miały obowiązek wybierać spośród swoich członków osoby zdolne i skłonne do ćwiczenia się w katechizmie, czytaniu i rachunkach, by nabyte umiejętności przekazywać parafianom i współbraciom ${ }^{279}$.

W działaniach charytatywnych doniosłe znaczenie przypisywał Poniatowski jałmużnie, która była jednym z głównych źródeł i metod gromadzenia funduszy przez bractwo. Miejsca i formy jej pozyskiwania oraz przechowywania i rozdzielania były ściśle sprecyzowane, by nie była ona sprzeniewierzana i wykorzystywana przez braci do własnych celów. Do zbierania jałmużny służyły zawieszone przy wejściu do kościoła małe skrzynki z otworem opatrzone napisem: „Karbona Jałmużny dla ubogich i chorych parafialnych". Były one zamykane trzema kluczami trzymanymi, każdy z osobna, przez starszego bractwa, jednego z radnych (asesorów) bractwa oraz rządcę kościoła parafialnego - najczęściej kapłana bractwa. Niezależnie od tego, we wszystkie niedziele i święta kilku członków konfraterni miało obowiązek zbierać pieniądze do skarbon przenośnych przed kościo$\jmath^{2} \mathrm{~m}^{280}$. Jałmużnę zbierano też po każdej pierwszej niedzieli miesiąca do skarbon przenośnych. Zajmowali się tym kolektorzy braccy, zaopatrzeni w specjalny dowód. Każdy z nich posiadał ściśle wyznaczony rewir zbierania datków oraz ustalony czas kwesty. Aby zapobiec nadużyciom, dozorca bracki sprawdzał, chodząc po parafii, czy kwestujący nie przywłaszczają sobie zebranych pieniędzy i nie

${ }^{275}$ Poniatowski, Ustanowienie [...] plockiey, s. 67; tenże, Ustanowienie [...] gnieźnieńskiey, s. $58-59$.

${ }^{276}$ Tenże, Ustanowienie [...] płockiey, s. 73-74; tenże, Ustanowienie [...] gnieźnieńskiey, s. 62.

277 Tenże, Ustanowienie [...] płockiey, s. 68, 73; tenże, Ustanowienie [...] gnieźnieńskiey, s. $59,61-62$.

${ }^{278}$ Flaga, Bractwa religijne w Rzeczypospolitej, s. 36; tenże, Bractwa religijne i przejawy, s. 63; Poniatowski, Ustanowienie [...] krakowskiey, s. 19-23.

${ }^{279}$ Poniatowski, Ustanowienie [...] płockiey, s. 24; tenże, Ustanowienie [...] krakowskiey, s. 23; tenże, Ustanowienie [...] gnieźnieńskiey, s. 24.

${ }^{280}$ Tenże, Ustanowienie [...] płockiey, s. 13-14; tenże, Ustanowienie [...] krakowskiey, s. 13-15; tenże, Ustanowienie [...] gnieźnieńskiey, s. 15-16. 
proszą o pomoc dla siebie ${ }^{281}$. Ofiary pieniężne zebrane w różny sposób do oddzielnych skrzynek deponowane były w karbonie generalnej, z której można było je wybierać na wspólnych spotkaniach bractwa ${ }^{282}$. Oprócz jałmużny pieniężnej, Poniatowski nawoływał do składania ofiar w naturze, które miały być następnie sprawiedliwie rozdzielane między potrzebujących ubogich ${ }^{283}$. Warto nadmienić, że do cotygodniowego dawania jałmużny zobowiązywali się także sami bracia już $\mathrm{w}$ momencie zapisu do stowarzyszenia ${ }^{284}$. Zbieraniem jałmużny zajmowali się ponadto sami mieszkańcy szpitali brackich.

Poruszając problem jałmużny, jako środka nieodzownego w prowadzeniu pracy charytatywnej, Poniatowski nawiązywał do wczesnochrześcijańskiej doktryny Ojców Kościoła o uniwersalistycznym pochodzeniu dób materialnych i konieczności dzielenia się nimi przez wszystkich ludzi, nawet ubogich, o ile nie są w skrajnej nędzy ${ }^{285}$. Toteż, według niego, każdy parafianin zobowiązany był do jej świadczenia. Powinna być ona jednak proporcjonalna do zamożności ofiarodawców. Zwracał się przeto w 1776 r. do kolektorów, by indywidualnie traktowali świadczących datki, i nie przyjmując niczego od bardzo biednych, przyglądali się bogatym, czy składana ofiara jest wystarczająca i adekwatna do posiadanych dóbr ${ }^{286}$. Biskupowi w całej idei pozyskiwania jałmużn nie chodziło tylko o zebranie datków dla potrzebujących, ale także o darczyńców, których chciał uczyć miłości do bliźniego. Zwracał się więc do braci, jak i do parafian: „....nie wystarcza naymnieysza [jałmużna], na przykład grosz, jeden od bogatego dany....287.

Obok zasadniczej misji służby biednym i chorym, bracia i siostry mieli codziennie modlić się za siebie i potrzebujących oraz za sprawy związane z podjętym dziełem charytatywnym. W sposób szczególny zobowiązani byli wraz z mieszkańcami szpitali do modlitw za dusze nieżyjących współbraci oraz do spełniania $\mathrm{w}$ ich intencji miłosiernych uczynków. Za zmarłych bractwo organizowało co roku mszę św. nazajutrz po Dniu Zadusznym. Wszyscy bracia musieli ponadto uczestniczyć w pogrzebach konfratrów ${ }^{288}$. Zabronione było jednak urządzanie styp pogrzebowych, w zamian za co zalecano oddawanie na rzecz bractwa „surowej leguminy”289. W porównaniu do konfraterni dewocyjnych, bractwa charytatywne, a więc i bractwo miłosierdzia, miały za naczelny cel działalność do-

${ }^{281}$ Tenże, Ustanowienie [...] ptockiey, s. 54-56; Kozik, Reforma, s. 66-67; Poniatowski, Ustanowienie [...] krakowskiey, s. 47-50; tenże, Ustanowienie [...] gnieźnieńskiey, s. 48-49.

${ }^{282}$ Tenże, Ustanowienie [...] płockiey, s. 66; tenże, Ustanowienie [...] gnieźnieńskiey, s. 58.

${ }^{283}$ Tenże, Ustanowienie [...] płockiey, s. 14-15; tenże, Ustanowienie [...] gnieźnieńskiey, s. 16-17.

${ }^{284}$ Grzybowski, Kościelna działalność, s. 182; Poniatowski, Ustanowienie [...] krakowskiey, s. $19-23$.

${ }^{285}$ V. Paglia, Storia, s. 116-139.

${ }^{286}$ Rozporządzenia y pisma pasterskie za rządów J.O. Xięcia Jerzego Poniatowskiego Biskupa Płockiego do Diecezyi Płockiey wydane dla wygody teyże ddeycezyi zebrane i do druku podane, t. 2, Warszawa 1785, s. 182.

${ }^{287}$ Kozik, Reforma, s. 68; Rozporzadzenia y pisma, s. 182

${ }^{288}$ Poniatowski, Ustanowienie [...] ptockiey, s. 19, 25; tenże, Ustanowienie [...] krakowskiey, s. 19-23; Flaga, Bractwa religijne i przejawy, s. 63; Grzybowski, Kościelna działalność, s. 181.

${ }^{289}$ Poniatowski, Ustanowienie [...] krakowskiey, s. 24. 
broczynną, a dopiero na drugim miejscu stawiały praktyki duchowe, jednak organizowanie pomocy ubogim i chorym połączone było w nich zawsze z praktykami religijnymi.

Choć bractwa zakładane po kolei w trzech różnych diecezjach wszędzie stawiały sobie ten sam cel, to jednak można w ich krótkim rozwoju dostrzec pewną ewolucję, wynikającą z chęci ulepszania zapoczątkowanego dzieła lub też dostosowania strategii działania do nowych i lokalnych potrzeb. W archidiecezji gnieźnieńskiej, większy nacisk kładziono na pomoc ubogim dzieciom, organizując im nawet szkoły, podczas gdy w diecezji płockiej i krakowskiej poprzestawano na niesieniu pomocy ubogim i chorym oraz wspomnianym już dokształcaniu członków bractwa ${ }^{290}$.

Jako przykład praktycznej działalności bractw miłosierdzia może posłużyć tego typu wspólnota pw. Adama i Ewy i św. Izydora Oracza założona w 1784 r. w parafii Krzyżanowice przez tamtejszego plebana Hugona Kołłątaja. Choć powstała ona na fali ogólnej akcji podjętej w tym zakresie przez Poniatowskiego, to jednak bezpośredni twórca i fundator nadał jej swoistą specyfikę. Podstawą funkcjonowania bractwa był kapitał w pieniądzach i zbożu pochodzący z dotacji plebana, składek członkowskich oraz dobrowolnych ofiar w zbożu. Z zebranych środków wydawano bezpłatne obiady dla ubogich, udzielano zapomóg oraz pożyczek pieniężnych i zbożowych dla chłopów na dorobku, zwłaszcza na przednówku. Bractwo miało pilnować, aby wszystkie miejscowe dzieci chodziły do założonej przez niego szkoły parafialnej. Ponadto postanowiło wybudować szpital parafialny, z wyodrębnioną salą sądowąa ${ }^{291}$.

Zainspirowany inicjatywą Poniatowskiego, swoją teoretyczną wizję bractwa miłosierdzia stworzył biskup inflancki, później wileński, Józef Kazimierz Kossakowski. Według tytułowego bohatera jego utworu Xiędza plebana, „miała to być jedyna instytucja dobroczynna w parafii, działająca przy pomocy sióstr miłosierdzia u boku plebana, dzięki której parafia miała się stać małą, bogobojną, praworządną i zasobną Rzeczypospolitą, na wzór której miała być zreformowana Rzeczpospolita Obojga Narodów"292. Bractwa te były jednym z przedsięwzięć w jawiącej się jako małe gospodarstwo parafii, do której pleban sprowadzał opłacanych $\mathrm{z}$ kasy konfraterni różnych rzemieślników, z zadaniem nauczania parafian i biednych wykonywania prostych rzeczy codziennego użytku ${ }^{293}$. Celem wspólnoty była materialna i duchowa pomoc ubogim, opatrywanie potrzeb kościoła, odwiedzanie chorych, świadczenie jałmużny ${ }^{294}$. W pracę charytatywną na rzecz potrzebują-

${ }^{290}$ Flaga, Działalność charytatywna, s. 381-382; tenże, Bractwa religijne w Rzeczypospolitej, s. 209.

${ }^{291}$ H. Kołłątaj, Listy Anonima i prawo polityczne narodu polskiego, t. 1, cz. III, Warszawa 1954, s. 143; S. Litak, Od Reformacji do Oświecenia. Kościót katolicki w Polsce nowożytnej, Lublin 1994, s. 205-206; Flaga, Działalność charytatywna, s. 382; tenże, Bractwa religijne w Rzeczypospolitej, s. 210.

${ }^{292}$ Litak, Parafie, s. 357-356.

${ }^{293}$ J.K. Kossakowski, Xiądz pleban, Warszawa 1786, s. 106-107. Chodziło o kapeluszników, szewców, garbarzy, kupców, garncarzy, cieślów, szklarzy, stolarzy.

${ }^{294}$ Tamże, s. 90-92, 140-141. 
cych w szczególny sposób miały angażować się wdowy, nazywane siostrami miłosierdzia. Te „,cnotliwe i religijne matrony” miały się opiekować chorymi w ich domach a także wspierać duchowo osoby bliskie śmierci ${ }^{295}$. Fundusz bractwa miłosierdzia Kossakowkiego stanowiły dochody z ołtarza oraz z rocznej kolędy, której zrzekł się na korzyść wspólnot pleban. Podobnie zresztą zrezygnował z opłat za chrzty, śluby i pogrzeby, w zamian za co parafianie zobowiązani byli wnosić do kasy bractwa pewne opłaty i kontrybuty zbożowe ${ }^{296}$.

Zarząd bractw miłosierdzia M. J. Poniatwskiego był podobny do występującego w bractwach tworzonych przez P. Skargę, z małymi jednak różnicami. I tu najważniejszą osobą był protektor - główny opiekun, czuwający nad całą konfraternią, wybierany jeden na dwa dekanaty. Jego obowiązkiem było m.in. pisanie odezw do biskupa i kontaktowanie się z nim${ }^{297}$. Realną władzę we wspólnocie brackiej pełnił jednak starszy, osoba świecka lub duchowna, najlepsza spośród wszystkich w konfraterni. Starano się, by obu funkcji nie dzierżyli przedstawiciele stanu duchownego, gdy więc protektor był kapłanem, seniorem zostawał świecki, i na odwrót. Starszy czuwał nad prawidłowym funkcjonowaniem organizacji, reprezentował ją na zewnątrz w kontaktach z urzędami świeckimi i kościelnymi, pilnował jej majątku, nadzorował pracę pozostałych urzędników. W gestii seniora leżało prawo zwoływania i prowadzenia schadzek, a także wnoszenia propozycji różnych zmian w bractwie ${ }^{298}$. Seniora wspomagali dwaj radni (asesorzy), którzy w sytuacji nieobecności starszego, mogli przewodniczyć schadzce ${ }^{299}$.

Formalnie nowymi funkcyjnymi w bractwach Poniatowskiego byli dozorcy, odpowiadający wizytatorom w bractwach Skargi. Mieszkali i pełnili swoją funkcję po parafiach (dwóch lub czterech) i wsiach (jeden lub dwóch), by lepiej poznać stan i liczbę potrzebujących, których po zarejestrowaniu należało otoczyć opieką. Ich powinnością było odwiedzanie chorych i ubogich co trzeci dzień lub raz w tygodniu, w zależności od oddalenia miejsca zamieszkania. Szukali też zatrudnienia osobom biednym, lecz zdolnym do pracy, a także pożyczali niezbędne do jej wykonywania sprzęty i narzędzia. Przeważnie były to, nieskomplikowane i lekkie zajęcia fizyczne, np. przędzenie wełny, kręcenie powrozów, plecienie kapeluszy, wyrabianie koszy czy grabi. Zdarzało się, że okoliczni rzemieślnicy sami szukali takich pracowników, najczęściej jednak trafiali oni do warsztatów z polecenia dozorców. To oni orzekali o zdolności podopiecznych do pracy i demaskowali symulantów korzystających z gratisowego wsparcia konfraterni. Zysk uzyskany z pracy oddawany był samym pracującym, lub bractwu z przeznaczeniem

295 Tamże, s. 126-128

${ }^{296}$ Czyż, Bractwo miłosierdzia, 27.

${ }^{297}$ Grzybowski, Kościelna działalność, s. 183; Poniatowski, Ustanowienie [...] krakowskiey, s. 53-54; tenże, Ustanowienie [...] płockiey, s. 60; tenże, Ustanowienie [...] gnieźnieńskiey, s. 5455.

${ }^{298}$ Poniatowski, Ustanowienie [...] krakowskiey, s. 31-33; tenże, Ustanowienie [...] płockiey, s. 35-36; tenże, Ustanowienie [...] gnieźnieńskiey, s. 32-33.

${ }^{299}$ Tenże, Ustanowienie [...] krakowskiey, s. 35; tenże, Ustanowienie [...] płockiey, s. 39-40; tenże, Ustanowienie [...] gnieźnieńskiey, s. 36-37. 
najczęściej na szpital parafialny ${ }^{300}$. Potrzebujący, którzy wyróżniali się w wykonywaniu zleconych prac, w razie choroby lub innego nieszczęścia mieli pierwszeństwo w przyjęciu do szpitala i uzyskaniu pomocy ${ }^{301}$. Oświeceniowa koncepcja miłosierdzia Poniatowskiego i jego podejście do problemu ubóstwa, stały absolutnie w opozycji do rozwiązań średniowiecznych, przybierały charakter utylitarny, uwzględniający potrzebę aktywizacji i resocjalizacji przez pracę ludzi nie posiadających środków do życia. Nie chodziło mu o bezkrytycznie świadczenie jałmużny zdolnym do pracy biedakom, która pogłębiała ich bezsilność i spychała na jeszcze głębszy margines społeczny, ale umożliwienie zatrudnienia z korzyścią dla nich samych i społeczeństwa.

Dozorcom pomagali i podlegali zarazem poddozorcy, których liczba uzależniona była od konkretnych potrzeb. Obowiązkiem ich było rozpoznanie środowiska nędzy i jego problemów, odwiedzanie chorych, tak w szpitalu, jak i pozostających w swoich domach, strzeżenie rzeczy oddanych na przechowanie przez szpitalników, pilnowanie, aby pomoc przyznana ubogim trafiała do najbardziej potrzebujących i nie była przeznaczana na alkohol i zbytek ${ }^{302}$. Wypraszaniem i zbieraniem jałmużny w bractwie miłosierdzia Poniatowskiego zajmowali się podlegli dozorcom kolektorzy ${ }^{303}$, nie występujący w bractwach Skargi. Przechowywanie i sprawiedliwe rozdzielanie jałmużn ubogim i chorym, w oparciu o wcześniej sporządzone spisy, powierzone było prokuratorowi (u Skargi szafarzom). Był on odpowiedzialny za pilnowanie ofiar, zdeponowanych w specjalnych pomieszczeniach, do których posiadał klucze ${ }^{304}$.

Szczególne miejsce w bractwie zajmował prowadzący całą administrację stowarzyszenia pisarz, odpowiedzialny za prowadzenie dwu ksiąg. W pierwszej zapisywał ważniejsze wydarzenia i uchwały schadzek, imiona wszystkich braci i datę ich wstąpienia do bractwa, ponadto imiona i dzień wpisu do bractwa ubogich $i$ chorych. W drugiej księdze odnotowywał przyjęte i wydane jałmużny pieniężne oraz w naturze, a także przedmioty codziennego użytku. Obowiązkiem pisarza było ponadto tworzenie corocznych raportów o stanie bractwa, przekazywanych kolejno plebanowi, następnie, dziekanowi, w końcu biskupowi. Ten ostatni był ostatnią instancją władzy dla bractw, które stworzył, nieformalnym ich protektorem i patronem ${ }^{305}$. Bractwa wymyślone, a raczej zrekonstruowane przez Poniatowskiego, podlegały jego nadzorowi i kontroli, którą przeprowadzał w oparciu

${ }^{300}$ Tenże, Ustanowienie [...] krakowskiey, s. 38-47; tenże, Ustanowienie [...] płockiey, s. 43-47; tenże, Ustanowienie [...] gnieźnieńskiey, s. 43-44.

${ }^{301}$ Kozik, Reforma, s. 50; Poniatowski, Ustanowienie [...] plockiey, s. 50; tenże, Ustanowienie [...] gnieźnieńskiey, s. 44-45

${ }^{302}$ Poniatowski, Ustanowienie [...] płockiey, s. 48-53; tenże, Ustanowienie [...] krakowskiey, s. $38-42$.

${ }^{303} \mathrm{O}$ nich wyżej przy omawianiu problemu jałmużny.

${ }^{304}$ Poniatowski, Ustanowienie [...] krakowskiey, s. 36-38; tenże, Ustanowienie [...] płockiey, s. 41; tenże, Ustanowienie [...] gnieźnieńskiey, s. 37.

${ }^{305}$ Tenże, Ustanowienie [...] krakowskiey, s. 51-53; tenże, Ustanowienie [...] płockiey, s. 58-59; tenże, Ustanowienie [...] gnieźnieńskiey, s. 51-53. 
o wizytacje dziekańskie ${ }^{306}$. Nad sferą duchową i wypełnianiem obowiązków dewocyjnych członków bractwa czuwał opiekujący się nimi kapłan - promotor bractwa, wybierany spośród księży pracujących w parafiii ${ }^{307}$. Zobligowany był on do urządzania duchowych czytań na temat uczynków miłosiernych, do których lekturę miały stanowić kazania Piotra Skargi. Promotor troszczył się o stan duchowy bractwa oraz ubogich i chorych. Tych ostatnich zobowiązany był odwiedzać raz w roku i udzielać im sakramentów, zbierać informacje o ich potrzebach, które następnie przekazywał bractwu $\mathrm{z}$ propozycją podjęcia środków zaradczych ${ }^{308}$. Oddzielne władze wybierano też dla kobiet zrzeszonych w bractwie, a mianowicie: starszą, dwie radne, czyli assesorki, prokuratorkę, dozorczynię i kolektorkę. Pisarzem całego bractwa był zawsze mężczyzna wybierany spośród braci ${ }^{309}$.

Omawianiu bieżących spraw służyły comiesięczne schadzki, organizowane dla braci w pierwszą niedzielę miesiąca. Siostry zaś raz w miesiącu zbierały się wraz z kapłanem i pisarzem, w trzecią niedzielę ${ }^{310}$. Po odmówieniu Ojcze Nasz i Zdrowaś Mario modlitwach i przeczytaniu fragmentów pism P. Skargi, poszczególni urzędnicy zdawali relację ze swojej pracy i informowali o sytuacji ubogich i chorych na terenie parafii. Wtedy też decydowano o rozdysponowaniu funduszy na poszczególne cele, w tym na szpital. W razie pilnej potrzeby, bracia mogli na bieżąco konsultować swoje potrzeby ze starszym konfraterni ${ }^{311}$.

\section{INNE BRACTWA CHARYTATYWNE}

W dużym stopniu charytatywne cele przyświecały stanowym bractwom kapłańskim, zrzeszającym księży diecezjalnych z najbliższej okolicy czy okręgów kościelnych, najczęściej dekanatów. W Europie zakładane już były w IX w. ${ }^{312}$ W Polsce rozwój tych organizacji przypadł na XIV i szczególnie XV w., jakkolwiek bractwo kapłańskie w Kołobrzegu, być może najstarsze, powstało już w 1267 r. ${ }^{313}$ Fraternitas albo Confraternitas presbyterorum, miały na naszych ziemiach charakter wybitnie religijno-ascetyczny i charytatywny. Dbając o pogłębianie pobożności i integrację środowiska katolickiego duchownych, zapewniały opiekę oraz pomoc materialną i religijną ubogim i chorym członkom wspólnoty, a na wypadek śmierci gwarantowały godny pogrzeb, msze święte i modlitwy za

${ }^{306}$ Kozik, Reforma, s. 56-58.

${ }^{307}$ Grzybowski, Kościelna działalność, s. 181.

${ }^{308}$ Flaga, Bractwa religijne i przejawy, s. 63; Czyż, Bractwo miłosierdzia, 27; Poniatowski, Ustanowienie [...] krakowskiey, s. 33-35; tenże, Ustanowienie [...] płockiey, s. 37-39; tenże, Ustanowienie [...] gnieźnieńskiey, s. 34-35.

${ }^{309}$ Grzybowski, Kościelna działalność, s. 181.

${ }^{310}$ Tamże, s. 182.

${ }^{311}$ Poniatowski, Ustanowienie [...] płockiey, s. 61-63; tenże, Ustanowienie [...] krakowskiey, s. 54-58; tenże, Ustanowienie [...] gnieźnieńskiey, s. 54-56.

${ }^{312}$ K. Kuźmak, Kapłańskie bractwa i stowarzyszenia, EK, t. 8, Lublin 2000, kol. 704-705; Flaga, Bractwa religijne w Rzeczypospolitej, s. 128.

${ }^{313}$ Wiśniowski, Bractwa religijne, s. 55, 59; Nowacki, Dzieje archidiecezji, s. 737. 
ich duszę ${ }^{314}$. Statuty bractwa kapłańskiego w Kościanie nakazywały odwiedzanie chorego brata, a w Braniewie choremu i ubogiemu bratu należało dawać zapomogę pieniężną ${ }^{315}$. Bractwo Kapłańskie Bożego Ciała w Toruniu utworzone w 1394 roku miało się zajmować nie tylko umacnianiem „kapłańskiej gorliwości” ale i udzielaniem pomocy podróżnym oraz grzebaniem zmarłych ${ }^{316}$. Statuty najstarszego bractwa kapłańskiego w Gdańsku (1374), podobnie jak i podobnych bractw w diecezji przemyskiej, nakładały na swoich członków obowiązek wzajemnej pomocy w wypadku choroby lub ubóstwa, a także zapewnienie im godziwego pogrzebu ${ }^{317}$. Był to uniwersalny cel tych konfraterni na ziemiach polskich, które wyraźnie posiadały znamiona stowarzyszeń dobroczynno-pogrzebowych. Bractwa kapłańskie trudno jest nieraz zidentyfikować, ponieważ przyjmowały dodatkowe wezwania patronalne kościołów i kaplic, przy których występowały oraz organizowały swoje spotkania i nabożeństwa ${ }^{318}$.

Choć w pierwotnym zamierzeniu były to konfraternie stanowe przeznaczone dla kapłanów, to jednak poprzez zapisywanie w poczet członków także osób świeckich obydwu płci, stawały się bractwami mieszanymi ${ }^{319}$. Taką specyfikę posiadało wspomniane bractwo toruńskie ${ }^{320}$. Również drugie bractwo kapłańskie przy kościele parafialnym Głównego Miasta Gdańska, przyjmowało do swego grona poza duchownymi, także kupców i rzemieślników ${ }^{321}$. By jednak nie zatracić kapłańskiego charakteru, niektóre bractwa ograniczały liczbę członków świeckich, w tym również kobiet. Postępowano tak np. w bractwie św. Doroty, założonym w 1400 r. przy kościele Trzech Króli w Elblągu ${ }^{322}$.

Bractwa kapłańskie były bardzo rozpowszechnione we wszystkich diecezjach polskich ${ }^{323}$. Wraz z bractwami ubogich oraz konfraterniami literackimi, należały do najbardziej popularnych w średniowieczu ${ }^{324}$, uważane przez niektórych za pierwowzór wszystkich średniowiecznych bractw religijnych ${ }^{325}$. Najbardziej i najwcześniej rozpowszechniły się na Pomorzu Zachodnim, w diecezji kamieńskiej, gdzie założono ich w tym okresie około $43^{326}$, zaś na Warmii w XV-XVII wieku

${ }^{314}$ Nowacki, Dzieje archidiecezji, s. 737; Wiśniowski, Bractwa religijne, s. 59; Budzyński, Dzieje opieki, s. 158; Kuźmak, Kapłańskie bractwa, kol. 704; Kopiczko, Ustrój i organizacja, s. 230-231; Diecezja chetmińska, s. 81.

${ }^{315}$ Wiśniowski, Bractwa religijne, s. 72.

${ }^{316}$ Czarciński, Bractwa, s. 48.

${ }^{317}$ Tamże, s. 42; Budzyński, Dzieje opieki, s. 158-159.

${ }^{318}$ Flaga, Bractwa religijne w Rzeczypospolitej, s. 128-129; Kuźmak, Kapłańskie bractwa, kol. 708.

${ }^{319}$ Kuźmak, Kapłańskie bractwa, kol. 704; Flaga, Bractwa religijne w Rzeczypospolitej, s. 128; Budzyński, Dzieje opieki, s. 157; Wiśniowski, Bractwa religijne, s. 59.

${ }^{320}$ Czarciński, Bractwa, s. 48.

${ }^{321}$ Tenże, s. 44.

${ }^{322}$ Kuźmak, Kapłańskie bractwa, kol. 708.

${ }^{323}$ Kumor, Kościelne stowarzyszenia, s. 328-329.

${ }^{324}$ Budzyński, Dzieje opieki, s. 157.

${ }^{325}$ Cyt. za: Bochnak, Religijne stowarzyszenia, s. 96.

${ }^{326}$ Wiśniowski, Bractwa religijne, s. 56, 59. 
$-8^{327}$. Na obu tych terenach nosiły, podobnie jak w Niemczech nazwę kalend, wywodzącą się stąd, że członkowie ich zwykli się zbierać na swe zgromadzenia w pierwszym dniu miesiąca. Określano je więc na Warmii mianem fraternitas calendarum (bractw kalendowych), a ich członków fratres calendarum ${ }^{328}$. W diecezji poznańskiej działało 21 konfraterni kapłańskich, 2 w Poznaniu. Jedną z nich dla ubogich kapłanów (Fraternitas Pauperum Sacerdotum) erygował w 1512 r. biskup Jan Lubrański. Posiadała ona własny szpital. Po najazdach szwedzkich konfraternia przekształciła się Fundusz Księży Ubogich, z którego kasy zasilano księży emerytów, starców i ubogich ${ }^{329}$. Również bractwo kapłańskie w Szamotułach przekształciło się po 160 latach istnienia w konfraternię pauperum sacerdotum. Dwa ostatnie przypadki sugerują, że niektóre bractwa wcześniej otwarte dla wszystkich duchownych, z czasem zrzeszały najuboższych kapłanów, a przynajmniej do nich wychodziły z pomocą ${ }^{330}$. Około 20 bractw kapłańskich istniało w diecezji wrocławskiej ${ }^{331}$. W XV w. występowały one w 4 parafiach diecezji przemyskiej, zaś do końca XVII w. powołano je w większości dekanatów tejże diecezji ${ }^{332}$. W diecezji krakowskiej w okresie od drugiej połowy XIV w. do połowy XVI w. odnotowano ich $13^{333}$, w tym tylko jedno w północnym archidiakonacie lubelskim, w Lublinie - założone przed 1495 r. przy kolegiacie ${ }^{334}$. Należeli do niego także duchowni z poza Lublina. Przychodząc z pomocą potrzebującym, zwłaszcza ubogim kapłanom, dawało ochronę przed lichwą oraz udzielało prawnej opieki duchowieństwu w jego finansowych sprawach ${ }^{335}$. Konfraternie kapłańskie występowały na terenie diecezji chełmińskiej, m.in. w Chojnicach, Lidzbarku, Grudziądzu, a także w diecezji włocławskiej ${ }^{336}$. Wzmianki o bractwa kapłańskich posiadamy również z terenu Semigalii i Pomezanii ${ }^{337}$. Wyraźny ich deficyt lub całkowity brak występował w diecezjach wschodnio-kresowych ${ }^{338}$. W $1522 \mathrm{r}$. zamierzano zaprowadzić bractwo duchowieństwa, mające na celu sprawowanie ekzekwii za zmarłych kapłanów w całej diecezji wileńskiej, ale czy ten pomysł się przyjął, nie wiadomo ${ }^{339}$.

W czasach nowożytnych większość konfraterni kapłańskich, podobnie jak

${ }^{327}$ Kopiczko, Ustrój i organizacja, s. 229.

${ }^{328}$ Wiśniowski, Bractwa religijne, s. 59; Bochnak, Religijne stowarzyszenia, s. 96.

${ }^{329}$ Nowacki, Dzieje archidiecezji, s. 738; Kumor, Kościelne stowarzyszenia, s. 322.

${ }^{330}$ Nowacki, Dzieje archidiecezji, s. 740.

${ }^{331}$ Wiśniowski, Bractwa religijne, s. 59; Kuźmak, Kapłańskie bractwa, kol. 708. Bochnak wymienia 4 bractwa kalendowe i 5 bractw altarystów na terenie diecezji wrocławskiej, które w gruncie rzeczy były stowarzyszeniami kapłanów (Religijne stowarzyszenia, s. 93-95, 96, 99).

${ }^{332}$ Budzyński, Dzieje opieki, s. 158; Wiśniowski, Bractwa religijne, s. 59.

${ }^{333}$ Wiśniowski, Bractwa religijne, s. 59.

${ }^{334}$ Flaga, Bractwa religijne $w$ archidiakonacie lubelskim do poczatku XVII wieku, s. 153, 155156; Wadowski, Kościoty, s. 151-152.

${ }^{335}$ Flaga, Bractwa religijne $w$ archidiakonacie lubelskim do początku XVII wieku, s. 156; Wadowski, Kościoty, s. 152.

${ }^{336}$ Diecezja chetmińska, s. 81.

${ }^{337}$ Wiśniowski, Bractwa religijne, s. 60.

338 Zob. wcześniej cytowane prace dotyczące diecezji wschodnich.

${ }^{339}$ Kurczewski, Biskupstwo, s. 119. 
bractwa ubogich, stopniowo zanikało ${ }^{340}$. Wiele z nich upadło w czasie reformacji, zwłaszcza na terenach o dużych wpływach protestanckich, w Wielkopolsce m.in. w: Miłosławiu, Wschowie, Zbąszyniu; inne zaś, jak np. na tym terenie w: Buku, Gostyniu, Śremie, Środzie przekształciło się w bractwa literackie ${ }^{341}$. Od końca XVI w. bractwa kapłańskie działały i funkcjonowały już na zasadzie pewnego wyjątku. W drugiej połowie XVIII w. tylko jedna taka wspólnota funkcjonowała w diecezji płockiej ${ }^{342}$, w diecezji krakowskiej nie było żadnej ${ }^{343}$. Do wyjątków należała północno-pomorska część diecezji włocławskiej z kilkoma bractwami kapłańskimi działającymi na początku XVIII stulecia ${ }^{344}$.

Konfraternie kapłańskie posiadały własne altarie, w diecezji poznańskiej niekiedy nawet więcej niż jedną ${ }^{345}$. Miały też swoich kapłanów brackich, tzw. kapelanów ${ }^{346}$, a także władze brackie. Na ich czele stali starsi, inaczej seniorzy, których liczba zależała od lokalnych potrzeb. W konfraterni szamotulskiej w 1485 r. było ich pięciu, w Łaskarzewie - czterech (około 1541), w Święciechowej - dwóch $(1486)^{347}$. Wszyscy oni byli duchownymi, co jeszcze bardziej podkreśla stanowy charakter tych organizacji i pokazuje drugoplanową, jeśli nie marginalną, rolę świeckich w strukturze władz, jak i ogółu członków.

Do stowarzyszeń charytatywnych należało bractwo dobrej śmierci, nie przez wszystkich zaliczane do tej kategorii ${ }^{348}$. Choć nastawione eschatologicznie, posiadało wyraźne cechy bractwa charytatywnego ${ }^{349}$, świadczyło bowiem opiekę moralną i duchowo-religijną ludziom stającym w obliczu śmierci. Celem tych bractw były posługi duszpasterskie, zmierzające do dobrego przygotowania jej członków i ludzi spoza konfraterni na śmierć, dokładniej do „dobrej śmierci” czy „dobrego umierania" 350 . Nawiązywały one do założonego przez Kamila de Lellis w $1587 \mathrm{r}$. we Włoszech stowarzyszenia, a następnie zakonu „ojców dobrej śmierci” nazywanego kamilianami, a w Hiszpanii patres agonizantes. Typowe bractwo dobrej śmierci założył w 1648 r. przy rzymskim kościele Il Gesu generał jezuitów Wincenty Carafa, dając w ten sposób wzór i bodziec do rozwoju tej instytucji w całej Europie ${ }^{351}$. W Polsce podobną wspólnotę, pod nazwą Kongregacja Dobrej Śmierci, zaprowadzono przy kościele św. Piotra i Pawła w Krakowie w 1690 r. ${ }^{352}$

${ }^{340}$ Flaga, Bractwa religijne w Rzeczypospolitej, s. 129; Nowacki, Dzieje archidiecezji, s. 740; Diecezja chetmińska, s. 81.

${ }^{341}$ Nowacki, Dzieje archidiecezji, s. 738-340.

${ }^{342}$ Flaga, Bractwa religijne w Rzeczypospolitej, s. 129; tenże, Bractwa religijne i przejawy, s. 39.

${ }^{343}$ Flaga, Rodzaje, s. 588-589.

${ }^{344}$ A. Mańkowski, Bractwo kapłanów w trzech dekanatach pomorskich, tczewskim, gniewskim i starogardzkim 1701-1735, Pelplin 1917; Diecezja chetmińska, s. 81.

${ }^{345}$ Nowacki, Dzieje archidiecezji, s. 740.

${ }^{346}$ Flaga, Bractwa religijne w archidiakonacie lubelskim do poczatku XVII wieku, s. 156.

${ }^{347}$ Nowacki, Dzieje archidiecezji, s. 740.

${ }^{348}$ Litak, Bractwa, s. 518.

${ }^{349}$ Budzyński, Dzieje opieki, s. 159.

${ }^{350}$ Flaga, Bractwa religijne w Rzeczypospolitej, s. 126.

${ }^{351}$ Tamże, s. 126; S. Załęski, Jezuici w Polsce, t. 2, Lwów 1902, s. 932;

${ }^{352}$ Flaga, Bractwa religijne w Rzeczypospolitej, s. 126-127; M. Włodarski, Ars moriendi w literaturze polskiej XV i XVI wieku, Kraków 1987, s. 62. 
Bractwa dobrej śmierci, w diecezji żmudzkiej nazywane też bractwami szczęśliwej śmierci ${ }^{353}$, złączone z jezuitami, przez nich propagowane i zakładane, rozwijały się w XVII i XVIII w. ${ }^{354}$. W latach 1754-1769 jezuici prowadzili 14 takich bractw dobrej śmierci w dwóch swoich prowincjach: małopolskiej (9) i wielkopolskiej (5), w 1772 r. w czterech prowincjach funkcjonowało 15 takich kongregacji: (litewskiej - 2, małopolskiej - 6, mazowieckiej - 3, wielkopolskiej - 4) s5 $^{355}$. Faktycznie więc nastąpiło wyraźne zmniejszenie ich stanu ilościowego, co zapewne wiązać należy z kryzysem i kasatą popierającego ich zakonu. Bractwa dobrej śmierci, jako wymysł i dzieło jezuickie, rozwijały się także niezależnie od placówek tego zakonu, w zwykłych parafiach. Ze względu na konieczny czas adaptacji wzoru rzymskiego, w Polsce zaczęły się pojawiać dopiero w drugiej połowie XVII w., i to raczej w schyłkowej jej fazie. Generalnie ich liczebność nie była wysoka. W diecezji wrocławskiej było ich $3^{356}$. W archidiakonacie lubelskim w okresie przedrozbiorowym odnotowano zaledwie jedno takie stowarzyszenie, założone w 1693 r. przy kościele jezuickim ${ }^{357}$. Należy przypuszczać, że podobnie było na pozostałych terenach diecezji krakowskiej, skoro w połowie XVIII w. nie było w niej żadnej takiej konfraterni ${ }^{358}$. Znacznie lepiej sytuacja wyglądała w diecezji poznańskiej, gdzie w ostatniej ćwierci XVIII stulecia odnotowano łącznie 24 bractwa dobrej śmierci i pokrewnych im bractw św. Barbary ${ }^{359}$. Pojedynczo bractwa dobrej śmierci można było spotkać i na innych terenach, np. w 1760 r. w parafii Poszumień na Litwie, gdzie cura animarum sprawowali karmelici bosi ${ }^{360}$, w Łańcucie (założone w 1701 r.) ${ }^{361}$, w Łucku przy kościele św. Piotra i Pawła (wprowadzone przez jezuitów w 1748 r.) (62 $^{362}$ We Lwowie działały nawet dwa stowarzyszenia dobrej śmierci, jedno założone w 1684 r. przy kościele jezuitów ${ }^{363}$ oraz drugie (Agonizantium et Mortuorum), istniejące już od 1660 r. pod wezwaniem patrona dobrej śmierci św. Józefa przy kościele karmelitów bosych, które tamtejsi zakonnicy przemianowali później na Bractwo Konających św. Józefa, chcąc w ten sposób bardziej wyeksponować jego cel, tzn. modlitwę za zmarłych $^{364}$. Niektóre bractwa dobrej śmierci starały się o pojednanie z Bogiem skazańców oraz organizowały ich pochówek po egzekucji ${ }^{365}$.

Kultowo-charytatywne oblicze reprezentowały fraternie Maryi Wspomoży-

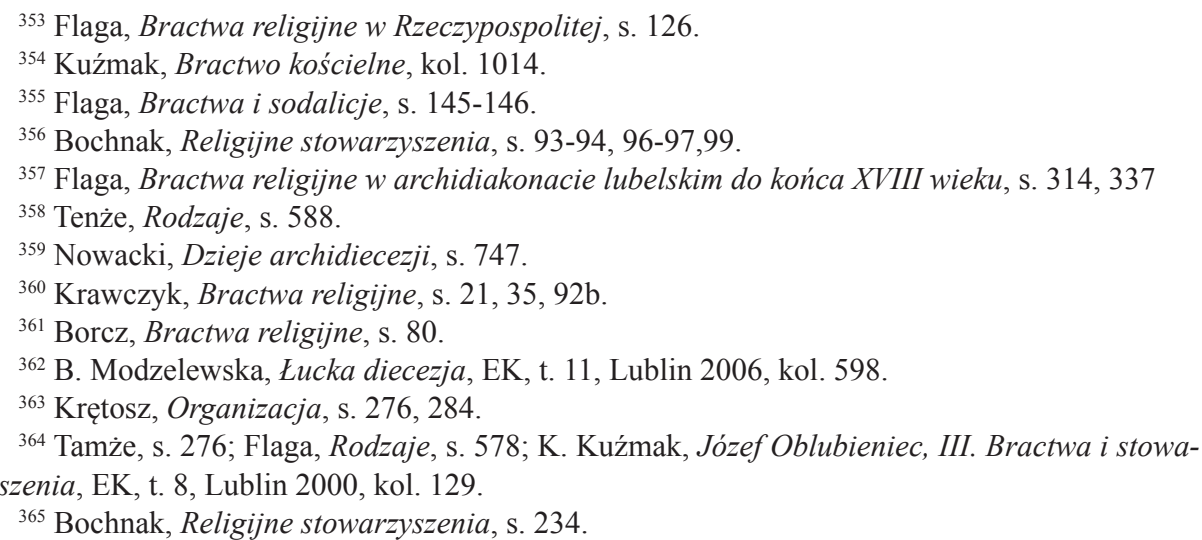


cielki Chrześcijan, noszące niekiedy nazwę bractw dobrej śmierci ${ }^{366}$. W diecezji łuckiej stwierdzono aż 16 takich wspólnot, a ich największy rozwój datuje się na drugą połowę XVIII stulecia ${ }^{367}$. Było ich też kilka na Śląsku. Jedna z takich konfraterni istniała przy kościele jezuitów w Lublinie. Osoby z nią związane udzielały jałmużn ubogim, a także odwiedzały z posługą chorych w szpitalach i prywatnych domach ${ }^{368}$.

Razem z bractwami dobrej śmierci rozwijały się od początku XVII w., bractwa pogrzebowe ${ }^{369}$. Jako że oba spotykały się w swojej działalności z problem umierania i śmierci, te pierwsze utożsamiano z drugimi, nazywając je niekiedy również pogrzebowymi. Konfraternie pogrzebowe prowadziły samopomoc bracką, głównie jednak gromadziły fundusze na pokrycie kosztów pogrzebów zmarłych konfratrów, urządzanych w uroczystej oprawie ${ }^{370}$. Takie zapewne cele realizowała trzecia lwowska konfraternia mortuorum o charakterze eschatologicznym, istniejąca przynajmniej od 1606 r. przy kościele NMP Śnieżnej we Lwowie ${ }^{371}$. Pogrzebowym było najpewniej powstałe około $1626 \mathrm{r}$. w Wilnie bractwo św. Nikodema „dla ratunku chorych na zarazę i do grzebania umarłych" ${ }^{372}$, a także kierujące małym szpitalikiem ${ }^{373}$. Niełatwo jednoznacznie zinterpretować, jaki typ bractwa kryje się pod określeniem mortuorum. Nazwa sugeruje, że były to konfraternie pogrzebowe, zajmujące się urządzaniem ceremonii funeralnych i chowaniem zmarłych, jednakże drugi człon tytułu (agonizantium) wspomnianego bractwa działającego przy karmelitach lwowskich, nie wyklucza że chodziło tam o opiekę nad umierającymi, a więc o bractwo dobrej śmierci. Zapewne zadania obu stowarzyszeń były podobne, często na siebie zachodziły i wzajemnie się uzupełniały. Nowożytne bractwa pogrzebowe nie były zjawiskiem całkowicie oryginalnym i nowatorskim, Miały swoje rzadkie pierwowzory już w średniowieczu na Śląsku: w Bolkowie (1410) i Chojnowie (1455), a także we Wrocławiu, w którym bractwo pod wezwaniem św. Barbary, działające od drugiej połowy XV w. nazywano pogrzebowym. Wszystkie trzy funkcjonowały jeszcze w XVII-XVIII wieku ${ }^{374}$. Należy przypomnieć, że wyraźny charakter bractw pogrzebowych posiadały też bractwa kapłańskie ${ }^{375}$.

Do bractw dobrej śmierci i pogrzebowych zbliżone było bractwo św. Barbary - patronki dobrej śmierci. Owo nastawienie na życie wieczne widoczne jest także

${ }^{366}$ K. Kuźmak, Bractwa Matki Boskiej Wspomożycielki Chrześcijan na Ziemiach polskich w XVIII stuleciu. Studium z dziejów kultu maryjnego i wspólnot chrześcijańskich w dawnej Polsce, Rzym 1993, s. 81.

${ }^{367}$ Królik, Organizacja diecezji, s. 340.

${ }^{368}$ Kuźmak, Bractwa Matki Boskiej Wspomożycielki, s. 183-185.

${ }^{369}$ Taż, Bractwo kościelne, kol. 1014.

${ }^{370}$ Budzyński, Dzieje opieki, s. 159.

${ }^{371}$ Krętosz, Organizacja, s. 276.

${ }^{372}$ Kurczewski, Biskupstwo, s. 15, 353, 357; Litak, Bractwa, s. 516. Ten drugi podał błędnie, że było to bractwo pod tytułem Nikodema.

${ }^{373}$ Karpiński, Opieka nad chorymi, s. 226.

${ }^{374}$ Bochnak, Religijne stowarzyszenia, s. 91-93, 97.

${ }^{375}$ Kumor, Kościelne stowarzyszenia, s. 328-329. 
w dążeniu do zapewnienia zmarłym członkom jak najbardziej godnego pogrzebu $^{376}$. Prowadziły też działalność charytatywną, zwłaszcza na rzecz ciężko cho$\mathrm{rych}^{377}$, co nadawało im znamiona stowarzyszeń dobroczynnych. Początki bractwa św. Barbary sięgają połowy XIV w. Jednym z bardziej znanych z tego okresu było bractwo przy kościele, noszącym takie samo wezwanie, w Krakowie, którym później kierowali jezuici. Do końca XVIII w. wpisano w rejestry brackie ponad 30000 członków, wśród nich znajdowali się królowie polscy, magnaci, szlachta, różnej hierarchii duchowni, nade wszystko mieszczanie. Ze względu na to, że św. Barbara czczona była głównie jako patronka konających, bractwo to rozwijało się przede wszystkim w okresach wojen i epidemii. W XVII i XVIII w. bractwa św. Barbary istniały prawie w całej Polsce, ciesząc się popularnością wśród ludzi wykonujących niebezpieczne zawody. Szczególnie licznie powstawały w ośrodkach górnictwa rud w rejonie kieleckim i częstochowskim oraz w śląskich ośrodkach górniczo-hutniczych ${ }^{378}$. Rozpowszechnione były również w XVII stuleciu w wielu kościołach diecezji poznańskiej z nabożeństwami i modłami o szczęśliwą śmierć ${ }^{379}$, a także w diecezji chełmińskiej - około 10 bractw XVIIXVIII w. ${ }^{380}$ Trzy takie bractwa odnotowano $\mathrm{w}$ archidiakonacie lubelskim ${ }^{381}$, dwa w prepozyturze wiślickiej ${ }^{382}$, w całej zaś diecezji krakowskiej działały w 11 parafiach. Były też w diecezji wrocławskiej- $6^{383}$, płockiej-4, przemyskiej-2 i żmudzkiej - $1^{384}$. Jedno bractwo o podwójnym wezwaniu św. Michała Archanioła i św. Barbary, założone w 1672 r. działało w Warce, w archidiakonacie warszawskim ${ }^{385}$. Konfraterni tych trudno było natomiast szukać na wschodnich obszarach Rzeczypospolitej ${ }^{386}$.

Utworzenie i działalność kilku bractw o podobnych i wspólnych celach, ukierunkowanych na udzielanie wsparcia umierającym, pomoc w organizacji pogrzebów i modlitwy za zmarłych, było odpowiedzią na potrzeby religijno-społeczne tych czasów i sytuację polityczną kraju. W Polsce nękanej wojnami, chorobami i innymi klęskami, śmierć stała się zjawiskiem nader powszechnym, do której starano się odpowiednio przygotować. W tej sytuacji popularne stały się zapo-

${ }^{376}$ Flaga, Bractwa religijne i przejawy, s. 58; tenże, Bractwa religijne w archidiakonacie lubelskim do końca XVIII wieku, s. 338.

${ }^{377}$ K. Kuźmak, Barbara św. III. Bractwa, EK, t. 2, Lublin 1985, kol. 17

${ }^{378}$ Tamże, kol. 17-18; J. Flaga, Rodzaje, s. 579.

${ }^{379}$ Nowacki, Dzieje archidiecezji, s. 748.

${ }^{380}$ Diecezja chetmińska, s. 83. (Oksywie, Grudziądz, Chełmża, Nowe, Lalkowy, Radowiska, Sierakowice, Walichnowy, Złotoryja, Torun, Fordon, Wudzyn, Szemud).

${ }^{381}$ Flaga, Bractwa religijne $w$ archidiakonacie lubelskim do końca XVIII wieku, s. 304, 310, 318, 338; tenże, Rekrutacja do bractw religijnych w XVII i XVIII wieku na przykładzie archidiakonatu lubelskiego, „Roczniki Humanistyczne”, 35 (1987) z. 2, s. 103-104, 109-110.

${ }^{382}$ E. Wiśniowski, Prepozytura, Lublin 1976, s. 31,172.

${ }^{383}$ Bochnak, Religijne stowarzyszenia, s. 88-91, 98.

${ }^{384}$ Flaga, Bractwa religijne w Rzeczypospolitej, s. 110.

${ }^{385}$ Kuźmak, Natoński, Bractwo Miłosierdzia, kol. 1021; Szwed, Bractwa religijne, s. 47, aneks. Autorka nazwała je bractwem zmarłych.

${ }^{386}$ Zob. cytowane wcześniej prace dotyczące diecezji: wileńskiej, kamienieckiej, brzeskiej, lwowskiej, przemyskiej, warmińskiej. 
czątkowane jeszcze w XV i XVI w. poradniki (podręczniki) „dobrej śmierci”, „dobrego umierania”, „czy sztuki umierania” oraz inne książeczki ze stosownymi modlitwami i pouczeniami ${ }^{387}$. Nie dziwi więc, że oprócz owych bractw w Polsce istniały jeszcze inne organizacje, mające na celu modlitwę za szczęśliwą śmierć, np. bractwa Konającego Pana Jezusa lub Konającego Serca Jezusowego, czy bractwa św. Józefa, będącego patronem dobrej śmierci ${ }^{388}$.

Niezbyt licznie na ziemiach polskich występowało bractwo św. Łazarza w pełni poświęcające się działaniom charytatywnym. Powstało ono na początku XII w., w Ziemi Świętej dla opieki nad trędowatymi. Szybko rozpowszechniło się we Francji i we Włoszech, gdzie prowadziło leprozoria i szpitale-lazarety. W czasach nowożytnych przechodziło różne przemiany, a popierane przez mecenasów sabaudzkich, ewoluowało w Piemoncie w kierunku bractwa rycerskiego ${ }^{389}$. W średniowiecznej Polsce konfraternia ta nie występowała, pomimo licznych na Śląsku, Pomorzu i Warmii leprozoriów ${ }^{390}$. W 1592 r. Piotr Skarga, ,widząc wielką liczbę żebraków w Krakowie" założył tam bractwo św. Łazarza, którego statut przewidywał: „raz w roku na wielkie dni pewny poczet sukien, koszul, butów i kożuchów rozdać między ubogie". W wymienionym dokumencie zwracano się też do braci: „po ulicach leżących do szpitalów wprowadzą, drugie leczyć będą, drugim chorym na miejscu, gdzie się przesunąc będą mogli, jałmużny posyłać będą"391. Konfraternię poparli niebawem na synodach diecezjalnych kardynał Bernard Maciejowski (1601) i biskup Marcin Szyszkowski (1621). Dzięki temu rozprzestrzeniła się ona po większych miastach polskich: w Warszawie (1592), Wilnie (1636), Krośnie (1695) i pomniejszych, np. w Tucholi na Pomorzu, Bolesławcu (1636), Pajęcznie (1771) ${ }^{392}$. Bractwo wileńskie utworzono do obsługi ufundowanego około 1600 r. szpitala św. Łazarza przy kościele św. Stefana ${ }^{393}$, natomiast warszawskie nie przypadkiem ustanowiono przy kościele noszącym również wezwanie św. Łazarza ${ }^{394}$. Członkowie bractw, oprócz świadczenia pomocy w szpitalach, zajmowali się zapewnieniem żebrakom schronienia, żywności, odzienia i pomocy medycznej ${ }^{395}$.

Charytatywny cel posiadało bractwo św. Rocha (patrona od morowej zarazy) założone około 1664 r. dla opieki nad chorymi przez biskupa poznańskiego Stefana Wierzbowskiego (1664-1687) przy kościele parafialnym św. Krzyża (księży

${ }^{387}$ Flaga, Rodzaje, s. 578; tenże, Bractwa religijne w Rzeczypospolitej, s. 127; G. Huszał, Przygotowanie do śmierci $w$ XVII wieku na podstawie poradników dobrego umierania, Lublin 1979 (mps, Archiwum KUL).

${ }^{388}$ Flaga, Bractwa religijne w Rzeczypospolitej, s. 127; tenże, Rodzaje, s. 578; Włodarski, Ars moriendi, s. 62-63; Kuźmak, Józef Oblubieniec, kol. 129.

${ }^{389}$ K. Kuźmak, Łazarz, III. Bractwa, EK, t. 11, Lublin 2006, kol. 348.

390 Wezwanie św. Łazarza posiadało wspomniane wcześniej późnośredniowieczne bractwo w Tucholi. Zob. wcześniejsze rozważania dotyczące bractw ubogich

${ }^{391}$ Cyt. za: Kumor, Kościelne stowarzyszenia, s. 523; tenże, Kościelne stowarzyszenia, s. 327.

392 Tamże, s. 523; tamże, s. 327.

${ }^{393}$ Kurczewski, Biskupstwo, s. 353, 358.

${ }^{394}$ Szwed, Bractwa religijne, aneks.

${ }^{395}$ Chodyński, Bractwo, s. 553; Kuźmak, Łazarz, kol. 438. 
misjonarzy) w Warszawie ${ }^{396}$, gdzie stało się współfundatorem szpitala pod tym samym tytułem ${ }^{397}$. Bractwo warszawskie stanowiło wspólnotę bardzo prężną i skuteczną w działaniu, o czym świadczy, zorganizowanie przy niej w $1743 \mathrm{r}$. banku pobożnego Mons Pietatis, zarządzanego przez braci i jednego z misjonarzy. Część jego kapitału przeznaczano na jałmużny dla ubogich wstydzących się żebrać, część na bezprowizyjne pożyczki dla będących w potrzebie ${ }^{398}$. Jego członkowie wsławili się też udzielaniem pomocy zarażonym w czasie epidemii dżumy, która nawiedziła Warszawę w latach 1709-1710 ${ }^{399}$. Bractwo nie nabrało szerszego zasięgu. Wiadomo, że występowało na terenie diecezji chełmińskiej (Grudziądzu - 1723, Tymowie - 1752, Nowem, Chełmży, Biskupim Popowie, Wabczu, Kijewie), było też jedno na Warmii, w Jonkowie (1739) ${ }^{400}$.

W trakcie wielkich epidemii aktywnością i poświęceniem odznaczało się bractwo św. Sebastiana, z reguły zakładane na okoliczność takich kataklizmów. Kiedy np. w 1633 r. panowała we Wrocławiu epidemia morowego powietrza powołano bractwo św. Sebastiana i Fabiana, które miało na celu niesienie pomocy w obliczu zbiorowego, niosącego śmierć zagrożenia ${ }^{401}$.

Oryginalną działalność charytatywną prowadziło bractwo św. Benona (opiekuna chorych), założone w 1623 r. w Warszawie przez jezuitę, pedagoga i kaznodzieję niemieckiego Jerzego Leyera i mieszczanina gdańskiego Jana Jaksę w celu niesienia pomocy materialnej i duchowej cudzoziemcom, zwłaszcza pochodzenia niemieckiego ${ }^{402}$. To niemieckie na początku bractwo utworzyło w 1626 r. i utrzymywało w stolicy szpital pod tym samym wezwaniem składający się z sierocińca, szkoły dla dzieci oraz schroniska dla ubogich i chorych pielgrzymów i podróżnych. Z założenia przeznaczony dla cudzoziemców $\mathrm{i}$ ich rodzin, w praktyce przyjmował także Polaków. Bractwo prowadziło też własny mons pietatis. Dzięki przywilejom króla Zygmunta III Wazy i Władysława IV wychowankowie sierocińca, w ogromnej części dzieci porzucone, uzyskali prawa obywatelskie oraz dostęp do wszystkich rzemiosł i urzędów miejskich ${ }^{403}$. Około połowy XVII w. przy szpitalu brackim wystawiono kościół pod wezwaniem św. Benona, który

${ }^{396}$ Nowacki, Dzieje archidiecezji, s. 749; Szwed, Bractwa religijne, s. 41, aneks; Diecezja chetmińska, s. 8; A. Schletz, Bractwo św. Rocha w Warszawie, „Caritas”, 7 (1946) nr 7, s. 10-13, nr 8, s. 5-8; S. Brzozecki, Roch, Roch z Montepellier. III. Bractwa, EK, t. 17, Lublin 2012, kol. 149-150; Podgórska-Klawe, Szpitale warszawskie, s. 61. Autorka błędnie datuje powstanie bractwa w Warszawie na rok 1626

${ }^{397}$ A. Schletz, Zarys historyczny zgromadzenia sióstr miłosierdzia w Polsce, NP, 12 (1960) s. 83.

${ }^{398}$ Flaga, Działalność charytatywna, s. 386-388; tenże, Bractwa religijne w Rzeczypospolitej, s. 215; Księga pamiątkowa trzechsetlecia zgromadzenia księży misjonarzy (1625-1925), Kraków 1925, s. 75; J. Kitowicz, Opis obyczajów za panowania Augusta III, Wrocław 1970, s. 28-29.

${ }^{399}$ Podgórska-Klawe, Szpitale warszawskie, s. 62.

${ }^{400}$ Diecezja chetmińska, s. 81; Kopiczko, Ustrój i organizacja, s. 227, 229.

${ }^{401}$ Bochnak, Religijne stowarzyszenia, s. 236.

${ }^{402}$ M. Surdacki, Lejer, Leyer Jerzy, EK, t. 10, Lublin 2004, kol. 698.

${ }^{403}$ Tamże; J. Bazydło, K. Kuźmak, Benon, Benno, EK, t. 2, Lublin 1976, kol. 274; A. Wejnert, Starożytności Warszawy, Warszawa 1857, t. 5, s. 2-5; Karpiński, Pauperes, s. 270-272, 299, 328; A. Owczarski, Redemptoryści benonici w Warszawie 1787-1808, Kraków 2003, s. 16-17; Szwed 
w 1787 r. wraz z bractwem przejęli redemptoryści, zwani stąd benonitami (benonami) ${ }^{404}$. Świetnie prosperujący ośrodek szpitalny został zniszczony w $1659 \mathrm{r}$. podczas najazdu szwedzkiego ${ }^{405}$, a jego działalność kontynuował Instytut Moralnej Opieki nad Dziećmi. Bractwo kierowane i otaczane opieką duchową przez jezuitów nadal prowadziło jednak swoją działalność. Zasłużyło się szczególnie podczas epidemii dżumy nawiedzających Warszawę w XVII i XVIII w.; oprócz usług pielęgnacyjnych i pogrzebowych dostarczało wówczas żywności ubogim i chorym mieszkańcom stolicy i okolic ${ }^{406}$. Podczas wielkiej fali morowego powietrza, jakie nawiedziło Warszawę w latach 1709-1712, bractwo „z niezłomną wytrwałością do samego ustania klęski, gorliwie udzielało pomocy bliźnim swoim". Ceną za heroiczną służbę i walkę z morem była śmierć 49 członków tejże konfraterni ${ }^{407}$. Warszawskie bractwo św. Benona przetrwało rozbiory i działało jeszcze w pierwszych dziesięcioleciach XIX w. przy kościele paulinów. Oprócz Warszawy istniało ono również od 1787 r. w Górze koło Żnina ${ }^{408}$.

Z uwagi na narodową w pierwotnym zamyśle specyfikę, bractwo św. Benona nawiązywało do bractwa niemieckiego istniejącego już 1426 r. przy kościele NMP Śnieżnej we Lwowie (było ono tam jeszcze w XVII w.) ${ }^{409}$, nade wszystko zaś do bractwa niemieckiego św. Marcina, założonego w 1640 r. przez murarza Hicklera przy kościele św. Anny w Wilnie. Celem bractwa wileńskiego było uczenie młodzieży początków nauk chrześcijańskich, obyczajów, opiekowanie się nawróconymi z protestantyzmu, żywienie i odziewanie ubogich, leczenie chorych i prowadzenie szpitala-przytułku św. Marcina dla cudzoziemców: Niemców, Francuzów, Włochów. Konfraternia ta przetrwała czasy rozbiorów służąc cudzoziemcom jeszcze w 1912 r. ${ }^{410}$ Ubogimi Włochami zajmowała się w XVII w. w Krakowie konfraternia włoska ${ }^{411}$.

Ze względu na wszechstronne działania opiekuńcze, charytatywnym można nazwać bractwo św. Mikołaja skupiające kapłanów i świeckich, erygowane w 1619 r. w Lublinie przy kościele pod tym samym wezwaniem. Jego członkowie zajmowali się ,wspomaganiem wdów, sierot opuszczonych, lub uciśnionych ludzi: obmyślaniem i udzielaniem posagów dla ubogich panien; odwodzeniem młodzieży od życia rozwiązłego; godzeniem zwaśnionych małżeństw; wspieraniem stowarzyszonych pod względem moralnym i materialnym; wreszcie wyszukiwa-

Bractwa religijne, aneks, s. 41,48; Łukaszewicz, Krótki opis, s. 120. Zob. też: Podgórska-Klawe, Szpitale warszawskie, s. 42-44.

${ }^{404}$ Owczarski, Redemptoryści benonici, s. 19-21; Wejnert, Starożytności, s. 4-5; Bazydło, Kuźmak, Benon, kol. 274.

${ }^{405}$ Surdacki, Lejer, kol. 698; S. Olczak, Instytut Moralnej Opieki nad Dziećmi, EK, t. 7, Lublin 1997, kol. 299-300; Karpiński, Pauperes, s. 273.

${ }^{406}$ Bazydło, Kuźmak, Benon, kol. 274; Karpiński, Opieka nad chorymi, s. 241.

${ }^{407}$ Wejnert, Starożytności, s. 18-19; Karpiński, Opieka nad chorymi, s. 226; Chodyński, Bractwo, s. 572.

${ }^{408}$ Bazydło, Kuźmak, Benon, kol. 274.

${ }^{409}$ Krętosz, Organizacja, s. 276.

${ }^{410}$ Kurczewski, Biskupstwo, s. 165,363.

${ }^{411}$ H. Komaryńska, Szpital Bonifratrów w Krakowie w XVII XVIII wieku, Lublin 2010, s. 33. 
niem osób, które są bez żadnych środków utrzymania, aby je wspierać jałmużną, dopokąd żyją, w razie zaś śmierci własnym kosztem po chrześcijańsku grzebać”. Bractwo, działające jeszcze w 1781 r., upadło w czasie „ostatnich zamieszek krajowych za istnienia Rzeczypospolitej" $" 12$.

Wspominano już, że jedną z powinności członków bractw miłosierdzia było odwiedzanie osób przebywających w więzieniach. W Europie, zwłaszcza we Włoszech tworzono bractwa wyłącznie poświęcające się tej misji wspierania i odwiedzania uwięzionych ${ }^{413}$. Bractwa więzienne, bardzo rzadko wprawdzie, występowały także na ziemiach polskich. We Wrocławiu działało bractwo św. Teresy (1758), stawiające sobie za cel m.in. zbieranie pieniędzy na wykup więźniów. Z kolei biskup łucki Marcin Szyszkowski założył w 1595 r. przy krakowskim kościele franciszkanów bractwo Compassionis Christi (Męki Pańskiej), zatwierdzone przez papieża w 1597 r. Oprócz nawracania niewiernych na prawdziwą wiarę, opiekowało się ono uwięzionymi, płaciło ich długi, odwiedzało w więzieniach, wypraszało skrócenie kary lub uwolnienie, nakłaniało skazanych do skruchy i sakramentu pojednania oraz przygotowywało do pobożnej śmierci. Otrzymało nawet przywilej wypuszczania na wolność jednego więźnia w każdy Wielki Piątek. Symbolem czynnego miłosierdzia ze strony braci było też wspólne zasiadanie do stołu z uwięzionymi w Wielki Czwartek i obmywanie im nóg ${ }^{414}$. Takie same przywileje miały też konfraternie krakowskie: Bractwo Górnicze oraz Męki Pań$s k i e j{ }^{415}$. To drugie organizowało składki, które umożliwiały więźniom spłatę długów i uzyskanie zwolnienia z dalszego odbywania kary. Gdy nie wystarczało środków, bractwa te, pozostające pod opieką franciszkanów, starały się o poprawę losu uwięzionych, dostarczały im jedzenie i ubranie oraz zapewniały opiekę duszpasterskąąi .

Wyłącznie do samego Wilna ograniczało swoją działalność stowarzyszenie miłosiernych osób pod tytułem Św. Zbawiciela założone w 1626 r. wraz ze skarbcem dla ubogich przez miejscowe duchowieństwo dla zapobieżenia srożącej się nędzy ${ }^{417}$.

Mówiąc o bractwach charytatywnych działających w różnych okresach, należy jeszcze wspomnieć o tych, które roztaczały opiekę nad pielgrzymkami, a w wypadku śmierci pątników, zajmowały się ich chrześcijańskim pogrzebem. $\mathrm{Na}$ terenie Polski tego rodzaju konfraternie występowały w XIV i XV w. w Ko-

${ }^{412}$ Wadowski, Kościoły, s. 86-87. Podobne bractwa istniały także w Benicach, Żydowie koło Poznania, Maniszewie koło Obornik. Nie wiadomo jednak nic o ich działalności charytatywnej. Zob. S. Brzozecki, B. Modzelewska, Mikołaj Święty, III. Bractwa i stowarzyszenia, EK, t. 12, Lublin 2008, kol. 971.

${ }^{413}$ V. Paglia, „La pietŕ dei carcerati”. Confraternite e societŕ a Roma nei secoli XVI-XVIII, Roma 1980; tenże, La morte confortata. Riti della paura e mentalitŕ religiosa a Roma nell'etŕ moderna, Roma 1982; Kuźmak, Bractwo kościelne, kol. 1021.

${ }^{414}$ Kumor, Kościelne stowarzyszenia, s. 329; Chodyński, Bractwo, s. 562-562.

${ }^{415}$ Kuźmak, Bractwo kościelne, kol. 1019-1020.

${ }^{416}$ Bochnak, Religijne stowarzyszenia, s. 234.

${ }^{417}$ Kurczewski, Biskupstwo, s. 15. 
szalinie, Kołobrzegu, Gryficach i Reszlu na Warmii ${ }^{418}$. Pielgrzymami opiekowały się rozpowszechnione już pod koniec XV w. na Warmii konfraternie św. Jakuba ${ }^{419}$. Bractwa te, występujące w XVI wieku w Braniewie, Dobrym Mieście, Lidzbarku, Ornecie, Pieniężnie, organizowały m.in. wspólne wigilie przy zmarłych i brały udział w pogrzebach ${ }^{420}$. Tak naprawdę, nieznany jest charakter i cel rzadko występującego na ziemiach polskich bractwa św. Jerzego. Jedna z wersji głosi, że było to bractwo kupców, założone w XV w. przy Kościele Mariackim w Gdańsku ${ }^{421}$. Przeczy jej częściowo informacja o pierwszym leprozorium gdańskim na Starym Mieście, powstałym w połowie XIV w., które od początku było zakładem bractwa św. Jerzego, zrzeszającego najbogatszych obywateli Głównego Miasta ${ }^{422}$. Zbieżność wezwania konfraterni z patronatem większości średniowiecznych leprozoriów w Polsce, nie wyklucza związku obu tych podmiotów, zważywszy, że z działającymi w końcu w XV w. bractwami św. Jerzego w Olsztynie i Braniewie, wspólistniały w tych miastach dwa szpitale - leprozoria noszące imię tego samego świętego ${ }^{423}$.

\section{DZIALALNOŚĆ CHARYTATYWNA BRACTW DEWOCYJNYCH}

Czynna miłość bliźniego była w większości bractw jednym z zasadniczych celów, dlatego również bractwa dewocyjne nie zaniedbywały działalności charytatywnej. Wprawdzie koncentrowały się przede wszystkim na odprawianiu różnych form kultu, to jednak w wielu $\mathrm{z}$ nich statuty wprost zalecały członkom czynienie odpowiednich aktów miłosierdzia wobec bliźnich ${ }^{424}$. Na mocy rozporządzenia synodalnego biskupa warmińskiego Szymona Rudnickiego z 1610 r. ,członkowie wszystkich bractw zobowiązani byli do szerzenia akcji charytatywnej, nawiedzania chorych, grzebania zmarłych, zachęcania do sakramentów św. Na ten cel bractwa przewidywały odpowiednie składki, czyniono odrębne zapisy i legaty ${ }^{425}$. We wszystkich bractwach, a więc i dewocyjnych, w pierwszym rzędzie pomoc i opieka odnoszona była do samych współbraci i własnej wspólnoty, co nadawało im znamiona korporacyjności ${ }^{426}$. Istnieje nawet, zbyt śmiały raczej, pogląd, że „udzielanie zasiłków miało zapobiec deklasacji środowiska brackiego" ${ }^{427}$. Statuty średniowiecznego bractwa tragarzy w Elblągu postanawiały, że obłożnie choremu

${ }^{418}$ Kumor, Kościelne stowarzyszenia, s. 328.

${ }^{419}$ Tamże, s. 327; Litak, Bractwa, s. 502.

${ }^{420}$ Por. Kopiczko, Ustrój i organizacja, s. 229, 231.

${ }^{421}$ K. Kużmak, Jerzy, Jerzy z Kapadocji. III. Bractwa i stowarzyszenia, EK, t. 7, Lublin 1997, kol. 1222.

${ }^{422}$ Kropidłowski, Formy opieki, s. 78, 87. Bractwo sprawowało też patronat nad leprozorium.

${ }^{423}$ Kopiczko, Ustrój i organizacja, s. 216, 218, 227, 229.

${ }^{424}$ Flaga, Bractwa religijne w Rzeczypospolitej, s. 205, 218; tenże, Działalność charytatywna, s. 377, 390; H. Wyczawski, Studia nad wewnętrznymi dziejami kościelnymi w Matopolsce na schytku XVI wieku, „Prawo Kanoniczne”, 7 (1964) nr 3-4, s. 59.

${ }^{425}$ Kopiczko, Ustrój i organizacja, s. 226.

${ }^{426}$ Wiśniowski, Bractwa religijne, s. 71; Czarciński, Bractwa, s. 21; Karpiński, Pauperes, s. 314; Zaremska, Bractwa, s. 167.

${ }^{427}$ Zaremska, Bractwa, s. 106. 
bratu należy się cotygodniowa zapomoga pieniężna z kasy wspólnoty, którą zobowiązany był zwrócić w wypadku wyzdrowienia ${ }^{428}$. Również w bractwie NMP w Krakowie seniorzy zobowiązani byli wspierać finansowo współbraci znajdujących się w trudnej sytuacji materialnej ${ }^{429}$.

Niezależnie od wspierania własnych członków, pomoc bractw dewocyjnych wychodziła także poza społeczności w nich zrzeszone. Świadczona była jak w wypadku wspomnianej konfraterni Mariackiej w Krakowie ,innym do bractwa nie należącym potrzebującym ${ }^{430}$. Inne bractwo krakowskie Matki Boskiej Polaków skupione przy obrazie w kaplicy Matki Boskiej w klasztorze augustianów, oprócz praktyk dewocyjnych zajmowało się także pielęgnowaniem chorych ${ }^{431}$.

Praca na rzecz potrzebujących znajdowała istotne miejsce $\mathrm{w}$ działalności powstałych w średniowieczu bractw literackich, pomimo że były to zrzeszenia religijne i oświatowe, a tylko w pewnej części charytatywne ${ }^{432}$. Ich nazwa wywodzi się stąd, że zrzeszały w swoich szeregach osoby obojga płci, posiadające umiejętność czytania i pewną znajomość łaciny (fratres litterati), a zatem mogących recytować śpiewy psalmy w czasie nabożeństw brackich oraz podczas niedzielnych i świątecznych mszy świętych. Oprócz rozwijania kultury duchowej członków i nauczania katechizmu, prowadziły działalność charytatywną, niosąc pomoc materialną ubogim i chorym współbraciom, wdowom i sierotom po zmarłych członkach wspólnoty, organizowały współbraciom pogrzeby i modliły się za ich dusze ${ }^{433}$.

Bractwa Literackie, zakładane pod patronatem Najświętszej Maryi Panny, przeżywały szczyt swego rozwoju w XV i XVI w. ${ }^{434}$ Wiele z nich, zwłaszcza z późniejszego okresu, wyłoniło się z dawnych konfraterni kapłańskich ${ }^{435}$. Do najstarszych należały bractwa w Bochni (1349), Lwowie (1387), Krośnie (1391) ${ }^{436}$. Rozpowszechnione były szczególnie w diecezji poznańskiej, krakowskiej, chełmińskiej, przemyskiej; pojedynczo występowały też w diecezji chełmskiej (Zamość), kamienieckiej (Gródek Podolski), czy wileńskiej (Kowno), lwowskiej ${ }^{437}$. W XVII i XVIII w. konfraternie literackie traciły już na znaczeniu, zaczęły podupadać, choć niektóre dotrwały do rozbiorów Polski ${ }^{438}$.

${ }^{428}$ Wiśniowski, Bractwa religijne, s. 72.

${ }^{429}$ Zaremska, Bractwa, s. 165-166.

${ }^{430}$ Tamże, s. 166.

${ }^{431}$ A. Szylar, Działalność wychowawczo-edukacyjno-opiekuńcza sióstr augustianek $w$ Krakowie do schyłku XIX wieku, w: Głodne dzieci w Polsce, red. Cz. Kępski, Lublin 2011, s. 294.

${ }^{432}$ P.P. Gach, Literackie Bractwa, EK, t. 10, Lublin 2004, kol. 1176.

${ }^{433}$ Wiśniowski, Bractwa religijne, s. 57; Gach, Literackie Bractwa, kol. 1176; Budzyński, Dzieje opieki, s. 158-159; Czarciński, Bractwa, s. 50.

${ }^{434}$ Flaga, Rodzaje, s. 571.

${ }^{435}$ Nowacki, Dzieje archidiecezji, s. 745. Zob. rozważania o bractwach kapłańskich.

${ }^{436}$ Gach, Literackie Bractwa, kol. 1177.

${ }^{437}$ Nowacki, Dzieje archidiecezji, s. 746-447; Szwed, Bractwa religijne, aneks; tenże, Literackie Bractwa, kol. 1177; Flaga, Bractwa religijne w archidiakonacie lubelskim do początku XVII wieku, s. 153-154; Flaga, Bractwa religijne w diecezji kamienieckiej, s. 616; Krętosz, Organizacja, s. 275; Krawczyk, Bractwa religijne, s. 88;

${ }^{438}$ Flaga, Rodzaje, s. 571-572. Przykładowo bractwo Literackie w Urzędowie, utworzone w 1489 r., w 1781 r. znajdowało się w stanie wegetacji, natomiast w roku 1801 już nie istniało. Zob. 
Bractwa literackie nie posiadały uniwersalnego oblicza, a zakres ich opiekuńczych działań zależał od warunków i zwyczajów lokalnych oraz od statutów tworzonych dla konkretnych konfraterni. Nie we wszystkich wpisany był obowiązek uczynków miłosierdzia chrześcijańskiego oraz świadczenia bliźnim pomocy materialnej i duchowej ${ }^{439}$. Na przykład w Brzozowie (diecezja przemyska) bractwo literackie tworzyło wspólny związek z miejscowymi żebrakami, którzy byli przyjmowani do konfraterni bez żadnych opłat wstępnych i posiadali przywilej zbierania jałmużny w pobliżu kościoła parafialnego. Mogli być oni nawet reprezentowani w łonie wspólnoty przez swojego przełożonego (seniora), mogli też mieć własny fundusz żebraczy. Podobne formy opieki nad ubogimi i żebrakami stosowano w bractwach literatów w Krośnie, Lesku, Mościskach, Rzeszowie ${ }^{440}$. Konfraternia literacka, funkcjonująca przy opactwie cystersów w Koprzywnicy, powoływała jałmużników zbierających jałmużnę (collectores elemosynae) oraz specjalnych wizytatorów do opieki nad chorymi i biednym (visitatores infirmorum) ${ }^{441}$. Istnieli oni również w analogicznym bractwie w Nowym Sączu. Ich powinnością, a także pozostałych braci, było „miłosierne uczynki duszne i cielesne czynić, ubogie w szpitalach, chore, więźnie nawiedzać", a także rozdzielać jałmużnę i godzić zwaśnionych ${ }^{442}$. Szeroki repertuar działań dobroczynnych wpisany był w obowiązki bractwa literackiego w Mławie. Jego członkowie obojga płci zobligowani byli wspierać ,stowarzyszonych dotkniętych kalectwem, chorobą, wiekiem, dopomagać ludziom moralnym i użytecznym, opiekować się ubogimi wdowami po zmarłych członkach, jako też wychowywać pozostałe sieroty"443.

W podobnym czasie, choć $\mathrm{w}$ dużo mniejszej skali, niż stowarzyszenia literackie powstawały bractwa strzeleckie pod wezwaniem Bożego Ciała, szerzące cześć Najświętszego Sakramentu oraz ćwiczące mieszczan w sztuce obronnej. Dobroczynny aspekt w ich działalności przejawiał się w obowiązku udziału w pogrzebach współbraci oraz zapewnianiu gościny biednym i obcokrajowcom ${ }^{444}$. Występowały one przede wszystkim na Warmii, gdzie w okresie od końca XIV do początku XVIII w. odnotowano ich 12. Do najstarszych należało bractwo w Ornecie $(1379)^{445}$. Sporadycznie spotkać je można było i na innych terenach, np. w Tarnowie ${ }^{446}$. Funkcją nawiązywały do nich rozwijające się prężnie na Śląsku od średniowiecza po czasy nowożytne bractwa kurkowe. Charytatywny aspekt ich dzia-

M. Surdacki, Bractwo Literackie w Urzędowie w latach 1489-1800, ABMK, 79 (2003) s. 429-444; tenże, Edukacja i opieka społeczna w Urzędowie w XV-XVIII wieku, Lublin, 2004, s. 151-154.

${ }^{439}$ Budzyński, Dzieje opieki, s. 159; Nowacki, Dzieje archidiecezji, s. 746.

${ }^{440}$ Budzyński, Dzieje opieki, s. 159.

${ }^{441}$ Flaga, Działalność charytatywna, s. 390; H. Ruciński, Bractwo literackie w Koprzywnicy jako obraz struktury miasteczka a latach 1694-1795, „Przegląd Historyczny”, 65 (1974) z. 2, s. 275 .

${ }^{442}$ B. Kumor, Statuty Bractwa Literackiego Nauki Chrześcijańskiej przy kolegiacie św. Małgorzaty w Nowym Sączu, ABMK, 2 (1961) s. 362, 376-377; Flaga, Działalność charytatywna, s. 390.

${ }^{443}$ D. Staszewski, Mława, Opis historyczny, Warszawa 1907, s. 39.

${ }^{444}$ Kopiczko, Ustrój i organizacja, s. 231.

${ }^{445}$ Tamże, s. 231; Litak, Bractwa, s. 502.

${ }^{446}$ Kumor, Prepozytura, s. 259. 
łalności przejawiał się $\mathrm{w}$ chęci realizowania średniowiecznego ideału obrony słabych i uciśnionych, reprezentowanego przez zakony rycerskie ${ }^{447}$.

Funkcje charytatywne towarzyszyły bractwom dewocyjnym aż do rozbiorów Polski. Zaznaczały się one szczególnie silnie w bractwach Sw. Trójcy, nawiązujących do charytatywnego bractwa Trójcy Przenajświętszej erygowanego w Rzymie w 1548 r. przez papieża Piusa V, nastawionego na wsparcie ubogich pielgrzymów i rekonwalescentów. W Polsce bractwo Św. Trójcy, niezależne od zakonu trynitarzy, założone w Poznaniu w 1632 r. przez niemieckich mieszkańców miasta przy kościele św. Anny, pielęgnowało również działalność dobroczynną. Opiekowało się chorymi podróżnymi, wydawaniem za mąż i uposażeniem ubogich panien. Było ono bardzo rozpowszechnione w Polsce po miastach i wioskach, zwłaszcza w XVIII w., np. w diecezji chełmińskiej ${ }^{448}$. W niektórych działalność charytatywna zajmowała eksponowane miejsce. Istniejące przy katedrze przemyskiej bractwo Św. Trójcy ubierało i utrzymywało trzech ubogich w zamian za uczestniczenie z zapalonymi świecami w uroczystych nabożeństwach brackich. Konfraternie „trynitarskie” wspierały też żebraków, chorych i ubogich w innych parafiach diecezji przemyskiej: Krośnie, Urzejowicach, Jarosławiu ${ }^{44}$. Celem bractwa Św. Trójcy w Wieluniu „,była opieka nad chorymi i ubogimi oraz inne uczynki miłosierdzia, m.in. wykup niewolników ${ }^{450}$. Bractwo Trójcy Przenajświętszej w diecezji wrocławskiej i na terenach objętych wojnami, podobnie jak zakon trynitarzy, podejmowało akcje mające na celu wykup jeńców z niewoli tureckiej, pomagało też biednym i chorym żołnierzom, którzy po opuszczeniu wojska pozostawali bez środków do życia. Gdy zagrożenie tureckie już nie występowało, bractwo Św. Trójcy zajęło się pomocą materialną dla opuszczonych dziewczą ${ }^{451}$. Opieką nad opuszczonymi dziewczętami, w tym również lekkich obyczajów, zajmowało się też bractwo Niepokalanego Poczęcia NMP w Nysie, które świadczyło im pomoc materialną oraz dawało skromny posag na wypadek zamążpójścia ${ }^{452}$. Wyposażaniem „biednych dziewic” zajmowały się też inne bractwa trynitarskie ${ }^{453}$.

Uczynki i nakazy dobroczynne realizowały bractwa różańcowe, które zobowiązywały swych członków do modlitwy i uczynków miłosiernych względem ciała, czy do pomocy ludziom żyjącym w nędzy (w Wieluniu) ${ }^{454}$. Bardzo różne formy przybierała działalność charytatywna tych bractw w diecezji przemyskiej. Tamtejsze konfraternie różańcowe przeznaczały corocznie pewne kwoty będą-

${ }^{447}$ Bochnak, Religijne stowarzyszenia, s. 101-103.

${ }^{448}$ Kumor, Kościelne stowarzyszenia, s. 328; Łukaszewicz, Krótki opis, s. 174; Nowacki, Dzieje archidiecezji, s. 749; Diecezja chetmińska, s. 84; Chodyński, Bractwo, s. 537.

${ }^{449}$ Budzyński, Dzieje opieki, s. 159-160. O bractwie krośnieńskim też: Flaga, Działalność charytatywna, s. 390-391; tenże, Bractwa religijne w Rzeczypospolitej, s. 219

${ }^{450}$ Flaga, Bractwa religijne w Rzeczypospolitej, s. 219; tenże, Dziatalność charytatywna, s. 390 .

${ }^{451}$ Bochnak, Religijne stowarzyszenia, s. 234.

${ }^{452}$ Flaga, Działalność charytatywna, s. 391.

${ }^{453}$ Chodyński, Bractwo, s. 537.

${ }^{454}$ Flaga, Bractwa religijne w Rzeczypospolitej, s. 219; tenże, Działalność charytatywna, s. 390 . 
cym w potrzebie ubogim, miejscowym szpitalom, czy też wynagradzały finansowo ubogich szpitalnych za posługi na rzecz wspólnoty i za codzienne śpiewanie w kościele różańca ${ }^{455}$.

Z działalnością dobroczynną konfraterni dewocyjnych można się było również spotkać na Litwie. Bractwo Niepokalanego Poczęcia NMP w Kukuciszkach po I rozbiorze Polski prowadziło ,szpital czyli bracki dom kosztem bractwa budowany". Z kolei w Tauroginach członkowie bractwa różańcowego udzielali pomocy bliźnim, zwłaszcza należącym do tej samej konfraterni, np. odwiedzali chorych, na co wskazuje istniejący w niektórych bractwach urząd wizytatora ${ }^{456}$. W drugiej połowie XV w., często spotykane w miastach śląskich, bractwo Bożego Ciała utrzymywało w Jaworze przytułek pod tym samym co konfraternia wezwaniem $^{457}$. W pełni charytatywną działalność uprawiało założone w 1579 r. przez Piotra Skargę bractwo Bożego Ciała w Wilnie. Jego celem było wspieranie ubogich przez jałmużnę i odwiedzanie co tydzień szpitali i więźniów, prowadziło też bank pobożny. Należeli do niego wszyscy możni na Litwie, w tym Lew Sapieha, który dawał na stowarzyszenie aż po 100 zł tygodniowo. Bardzo bogate bractwo, zarządzane przez jezuitów, posiadające około 20 domów, mnóstwo placów i liczne kapitały, zaprzestało działalności po kasacie protegującego go zakonu ${ }^{458}$. Pewne elementy działań dobroczynnych przejawiało też bractwo Bożego Ciała założone w 1596 r. w Lublinie, którego członkowie asystowali kapłanowi niosącemu Najświętszy Sakrament do chorych, a w wypadku braku opieki ze strony rodziny nawiedzali chorych i wspierali ich materialnie i moralnie ${ }^{459}$.

Bardzo wyraźnie funkcje charytatywne przewijały się w statutach rzadko występującego na terenach Rzeczypospolitej w XVII w. bractwie św. Izydora Oracza, którego celem była opieka duszpasterska nad ludnością wiejską ${ }^{460}$. Wśród wielu powinności jego członkowie zobligowani byli: ,chore w sąsiedztwie nawiedzać, cieszyć i w potrzebie ratować, do używania świętych sakramentów nauką, radą, pomocą przysposabiać". Zachętę do świadczenia miłosierdzia była obietnica otrzymania sześćdziesięciu dni odpustu za każdy dobry uczynek na rzecz potrzebujących ${ }^{461}$.

Jednym z przejawów działalności bractw, o znamionach częściowo charytatywnych, było udzielanie przez nie pożyczek na dużo korzystniejszych warunkach niż u nieuczciwych, trudniących się lichwą bankierów. Z kredytów pobieranych z kasy i funduszów brackich korzystali zarówno ich członkowie, jak i jak i osoby z zewnątrz, które znalazły się w potrzebie ${ }^{462}$. Takie praktyki można było

${ }^{455}$ Tenże, Działalność charytatywna, s. 394; Borcz, Bractwa religijne, s. 147.

${ }^{456} \mathrm{E}$. Krawczyk, Bractwa religijne w niektórych dekanatach diecezji wileńskiej w II połowie XVIII wieku, Lublin 2001, (mps, Archiwum KUL), s. 20-21.

${ }^{457}$ Dola, Szpitale średniowieczne Ślaska, s. 270.

${ }^{458}$ Kurczewski, Biskupstwo, s. 367.

${ }^{459}$ Wadowski, Kościoly, s. 149.

${ }^{460}$ K. Kuźmak, Izydor Oracz, EK, t. 7, Lublin 1997, kol.

${ }^{461}$ Łukaszewicz, Krótki opis, s. LIII, LV.

${ }^{462}$ Bochnak, Religijne stowarzyszenia, s. 232-233; Flaga, Dziatalność charytatywna, s. 391392. 
spotkać w typowo dewocyjnym bractwie św. Anny, funkcjonującym przy kościele parafialnym w Urzędowie, które bardzo często użyczało kredytów w XVII-XVIII w. zwykłym mieszkańcom miasta, jak również osobom wpływowym i zamożnym ${ }^{463}$. Zresztą bractwo św. Anny, wprowadzone przez bernardynów, w statucie z 1590 r. na marginesie swej działalności religijno-kultowej, wyraźnie uwzględniało też zadania i czyny miłosierdzia. Ich realizacji służyła umieszczona w kościele skrzynka na jałmużnę, do której bracia i wierni składali ofiary na rzecz potrzebujących. Do uiszczania jałmużny dla biedaków zobowiązani byli nade wszystko ci, którzy nie wzięli udziału w pogrzebach zmarłych konfratrów ${ }^{464}$.

Na uwagę zasługuje działalność charytatywna, podobnych do bractw, jezuickich sodalicji studenckich, nazywanych też ze względu na szerzenie kultu Matki Boskiej sodalicjami mariańskimi. Zasadniczym celem tych stowarzyszeń, skupiających studentów i uczniów, było połączenie studiów z życiem chrześcijańskim i zdobywaniem duchowej formacji ${ }^{465}$. W praktyce jednak cel ten był szerszy i bardziej wieloraki. Jak pisze Stanisław Bednarski, ,Sodalsi uczyli dzieci katechizmu, opiekowali się ubogimi, chorymi po szpitalach i przytułkach, więźniami, a opieka ta była bezpośrednią, usługiwano chorym, podawano pokarm, uczono katechizmu, przygotowywano do spowiedzi" ${ }^{466}$. Nieśli oni pomoc nie tylko duchową, ale leczyli też ciała, posługując m.in. zapowietrzonym w czasie epidemii. Ich duchowni opiekunowie bywali niekiedy kapelanami szpitalnymi i więziennymi ${ }^{467}$. Sodalicja jezuicka w Jeleniej Górze na początku XVIII w. rozpoczęła akcję która można uznać za pierwowzór apostolstwa chorych. Polegała ona na odwiedzaniu chorych współbraci oraz osób niezrzeszonych w domach, a także innych chorych w szpitalach ${ }^{468}$.

Na szczególną uwagę zasługują bractwa o charakterze zawodowo-klasowym, zbliżone mocno do cechów rzemieślniczych. Takim było bractwo tragarzy w Elblągu $^{469}$, czy bractwo tragarzy działające w XIV w. w Wieliczce i Bochni. Miało ono charakter religijny, ale rozwijało też działalność charytatywną, podobnie jak bractwo jak samopomocowe bractwo górników w Tarnowskich Górach ${ }^{470}$. Cele opiekuńcze przyświecały bractwu żeglarzy w Gdańsku, które ufundowało dla swoich członków szpital św. Jakuba czyli zakład Związku Gdańskich Kapitanów Morskich $^{471}$.

${ }^{463}$ M. Surdacki, Bractwo św. Anny w Urzędowie (1593-1787), „Roczniki Nauk Społecznych”, 30 (2002) z. 2, s. 143; tenże, Urzędów w XVII-XVIII wieku. Miasto - Społeczeństwo - Życie codzienne, Lublin 2007, s. 446.

${ }^{464}$ Łukaszewicz, Krotki opis, s. LI.

${ }^{465}$ Sodalicja mariańska, w: Encyklopedia wiedzy o jezuitach, red. L. Grzebień, Kraków 1996, s. 629 .

${ }^{466}$ S. Bednarski, Upadek i odrodzenie szkół jezuickich w Polsce. Studium z dziejów kultury i szkolnictwa polskiego, Kraków 1933, s. 404-405.

${ }^{467}$ Flaga, Działalność charytatywna, s. 391-392; tenże, Bractwa religijne w Rzeczypospolitej, s. 218; Kuźmak, Bractwa Matki Boskiej, s. 194-195.

${ }^{468}$ Kurczewski, Biskupstwo, s. 234.

${ }^{469}$ Wiśniowski, Bractwa religijne, s. 72. Było o nim wyżej.

${ }^{470}$ D. Molenda, Opieka zdrowotna i społeczna górników olkuskich w XV-XVIII wieku, w: Szpitalnictwo w dawnej Polsce, red. M. Dąbrowska, J. Kruppé, Warszawa 1998, s. 59

${ }^{471}$ Kropidłowski, Formy opieki, s. 79-80. 
Przykładów wspólnot brackich, które łączyły praktyki i działalność o charakterze dewocyjnym z aktywnością charytatywną, było o wiele więcej ${ }^{472}$, a te które przedstawiono tylko symbolicznie pokazują zaangażowanie, jeśli nie wszystkich, to prawie wszystkich konfraterni religijno-dewocyjnych w niesienie pomocy potrzebującym.

\section{PODSUMOWANIE}

Rozpatrując charytatywną działalność bractw kościelnych w średniowieczu i czasach nowożytnych, można powiedzieć, że w zasadzie wszystkie, bez względu na stawiane sobie zasadnicze cele, podejmowały w jakimś stopniu tę formę aktywności. Ze względu jednak na zakres i intensywność takich działań wyodrębniają się wśród nich trzy grupy. Pierwszą stanowią bractwa, o powszechnym ogólnopolskim zasięgu, które w momencie powstawania i w zamyśle ich twórców, stawiały sobie za główny, a nawet jedyny cel kompleksową pracę charytatywną skierowaną do wszystkich ludzi wymagających wsparcia, przybywających zarówno w szpitalach, w prywatnych domach lub gdziekolwiek indziej. Należy do nich zaliczyć bractwa szpitalne, bractwa ubogich oraz bractwa miłosierdzia. W grupie drugiej można umieścić także konfraternie charytatywne, lecz ilościowo mniej popularne, ograniczone do pewnych terenów, koncentrujące się na wybranych aspektach działan charytatywnych (np. wspieranie umierających), obejmujące opieką tylko niektóre grupy potrzebujących, niekiedy obsługujące pojedyncze szpitale. W tym wypadku chodzi m.in. o bractwa: kapłańskie, dobrej śmierci, niemieckie, pogrzebowe, więzienne, św. Marcina, św. Rocha, św. Benona, św. Łazarza. I wreszcie trzecia grupa bractw, to nastawione na zupełnie inne cele konfraternie dewocyjne, w których aktywność dobroczynna, z reguły uboczna, mało eksponowana, czasami wręcz marginalna, była jednak zawsze obecna. W wielu bractwach ograniczała się co najwyżej do obowiązku organizowania pochówku, uczestnictwa w ceremoniach pogrzebach konfratrów oraz modlitw za ich dusze.

Niełatwo jest stworzyć klarowną periodyzację bractw charytatywnych. Tylko niektóre bowiem związane były z konkretną epoką, jak bractwo św. Rocha, św. Benona czy w podwójnym swoim obliczu (potrydenckim i oświeceniowym) bractwo miłosierdzia. Do końca jednoznacznej tożsamości czasowej nie posiadały nawet średniowieczne konfraternie ubogich, a zwłaszcza kapłańskie, które w mniejszym (pierwsze) czy większym (drugie) zakresie kontynuowały swą działalność także w okresie staropolskim. Z kolei typowo mediewistyczne bractwo szpitalne, znajdowało później swoje analogie, w innych bractwach charytatywnych obsługujących konkretne szpitale (św. Łazarza w Wilnie). Niektóre działały na pograniczu epok, inne zaś rozwijające się czasach nowożytnych miały swoje korzenie w poprzedniej epoce (św. Barbary).

Podział bractw charytatywnych w aspekcie chronologicznym i dokonana typologia, posiadają charakter subiektywny a zarazem autorski, przez to być może dyskusyjny. Typowym przykładem trudności w klasyfikowaniu omawianych sto-

${ }^{472}$ Szersza analiza tego problemu, choć również sondażowa zamieszczona jest w artykule: Flagi, Działalność charytatywna, s. 390-397. 
warzyszeń jest bractwo Św. Trójcy, którego częsta i wieloraka aktywność opiekuńcza plasuje go na pograniczu konfraterni dewocyjnych i charytatywnych, co sprawia, że trudno go jednoznacznie zaliczyć do jednej lub drugiej grupy.

słowa kluczowe: bractwa religijne, bractwa charytatywne, bractwa szpitalne, bractwa miłosierdzia, Piotr Skarga, Michał Jerzy Poniatowski

\title{
BROTHERHOODS OF CHARITY IN POLAND FROM THE MIDDLE AGES TO THE LATE EIGHTEENTH CENTURY
}

\begin{abstract}
Summary
Religious brotherhoods were one of the institutions, apart from schools and hospitals, which in past centuries played an important role in the lives of individual parishes, towns and villages. They were associations - church communities, with legal personality, bringing together people for religious purposes, regardless of gender and social origin.

Different kinds of brotherhoods, including the ones of charitable and protective nature became a common phenomenon between the 11th and the 15th centuries in the West. In the thirteenth century, they also began to take hold on Polish soil, referring to Western patterns.

Hospital fraternities (fraternitas hospitales) have the oldest tradition of secular charities in the Polish land. Their aim was to provide people, who often did the activities connected with the medieval hospital. Some of them even founded and ran hospitals. Just like all other religious brotherhoods, at the earliest, in the thirteenth century, they appeared in Silesia. In the group of hospital fraternities the brotherhood of the Holy Spirit played a special role. That brotherhood was associated only with hospitals run by the Order of the same name, so-called 'duchaki'.

Brotherhoods of the poor were far more common in the Polish land. Their main aim was to focus on charitable activities and they encompassed almost all the lands of the Polish Republic. Their heyday was primarily in the fifteenth and the early sixteenth century. Brotherhoods of the poor developed evenly in terms of chronology in the whole land of the Polish state. Those fraternities exercised complete control over the lives of every beggar who was in the town; they regulated districts, begging procedures and oversaw the behaviour of the poor. The chief duty of brotherhoods of the poor was to take care of the sick in hospitals and their homes. The duty of brothers was also a concern for the dead, especially the poor and homeless, Christian burial and funeral as well as the prayers for those whom they took care of.

In the atmosphere of the reforms of the Council of Trent (1545-1563), religious brotherhoods began again spontaneously developing in Poland. The most important of the new
\end{abstract}


brotherhoods of charity was a brotherhood of mercy, established at the end of the sixteenth century by the preacher Jesuit Piotr Skarga. The first model brotherhood of mercy was organized by Skarga in 1584, and it was attached to the Jesuit Church of St. Barbara in Krakow. Other brotherhoods, based on Skarga's pattern, were formed in major cities of the Polish Republic, including Vilnius, Warsaw, Poznań, Pułtusk, Łowicz, Lviv, Zamość, Rzeszów, Lublin, Przemyśl. The period of the development of brotherhoods of mercy occurred in the late sixteenth and early seventeenth century. Then those organizations gradually disappeared and were forgotten.

The idea of Piotr Skarga's brotherhoods of mercy was renewed in the new spirit of the Enlightenment in the 1770s by Bishop, later Primate Michał Jerzy Poniatowki. They were not to be one of many brotherhoods, but the ones to which the others were to be "subordinate". Poniatowski incorporated all the previous devotional confraternities into them, along with their funds, used henceforth for the purpose not so much pious as socially useful. Reborn in the era of the first partition, brotherhoods of mercy, compared to their earlier prototype, due to the obligation of establishing them at every parish, had a more common and universal character, and were involved in more diverse charitable, social and educational activities.

Apart from the above mentioned brotherhoods of charity, which were the most famous and widespread in the Polish land in the Middle Ages and modern times, there were a number of other charitable associations. Those were: brotherhoods of priests, brotherhoods of good death, funeral brotherhoods, brotherhoods of St. Barbara, brotherhoods of St. Lazarus, brotherhoods of St. Roch, brotherhoods of St. Sebastian, brotherhoods of St. Benon, brotherhoods of St. Nicholas and St. Jacob.

Some devotional brotherhoods also dealt with charity. Although they mainly focused on the celebration of different forms of worship, the statutes of many explicitly advocated doing the acts of mercy toward other people. A brotherhood which stood out in this field was the literary one.

Keywords: religious brotherhoods, brotherhood of charity, hospital fraternities, brotherhood of mercy, Piotr Skarga, Michał Jerzy Poniatowski 